\title{
Copper-Catalyzed Hydroamination of Oxa- and Azabenzonorbornadienes with Pyrazoles
}

\author{
Kundo Kim and Yunmi Lee* \\ ${ }^{a}$ Department of Chemistry, Kwangwoon University, Seoul 01897, Republic of Korea \\ E-mail:ymlee@kw.ac.kr
}

\section{Supplementary Information}

\section{Table of Contents}

1. Copies of ${ }^{1} \mathrm{H}$ and ${ }^{13} \mathrm{C}\left\{{ }^{1} \mathrm{H}\right\}$ NMR spectra for all products $\quad$ S2

2. 2D-NOESY proton NMR spectra of compound $\mathbf{3 c a}, \mathbf{3} \mathbf{c b}, \mathbf{3 h}$ and ${ }^{1} \mathrm{H}$ NOESY S37 correlations

3. X-ray crystallographic data for $\mathbf{3 d}$ 
Copies of ${ }^{1} \mathrm{H}$ and ${ }^{13} \mathrm{C}\left\{{ }^{1} \mathrm{H}\right\}$ NMR spectra for all products

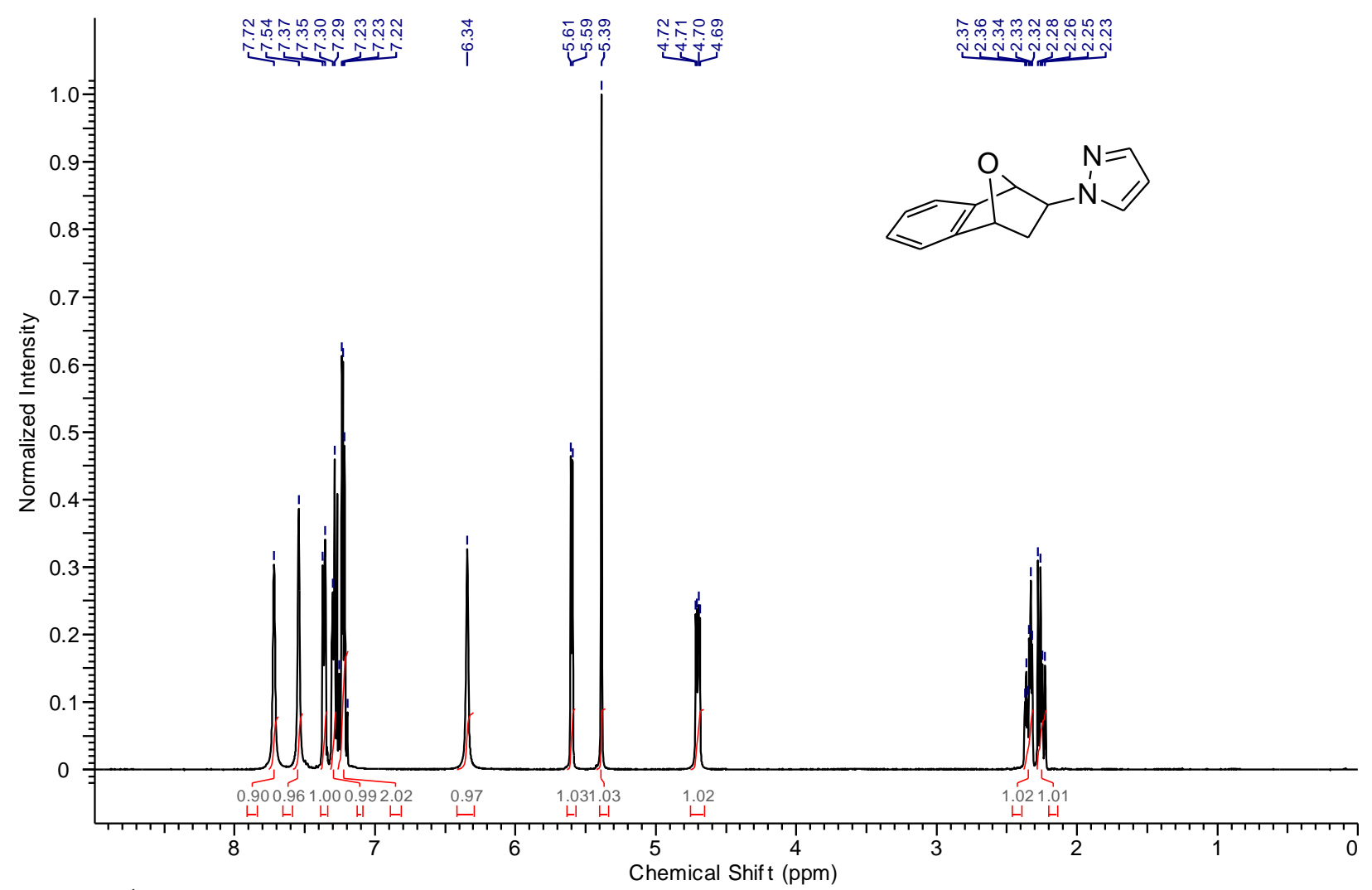

Figure S1. ${ }^{1} \mathrm{H}$ NMR spectrum of the compound 3a in $\mathrm{CDCl}_{3}, 400 \mathrm{MHz}$

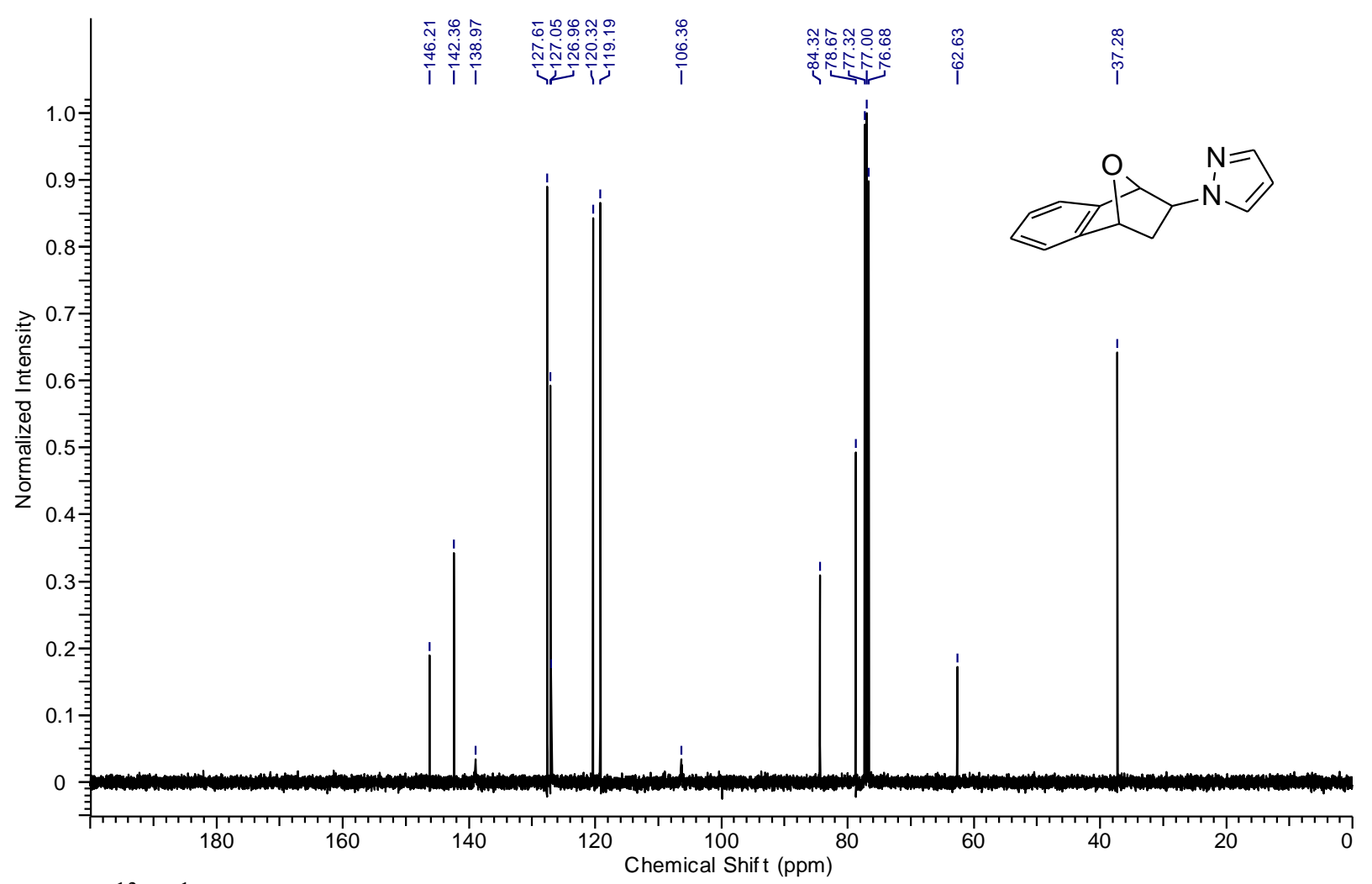

Figure S2. ${ }^{13} \mathrm{C}\left\{{ }^{1} \mathrm{H}\right\}$ NMR spectrum of the compound 3a in $\mathrm{CDCl}_{3}, 100 \mathrm{MHz}$ 


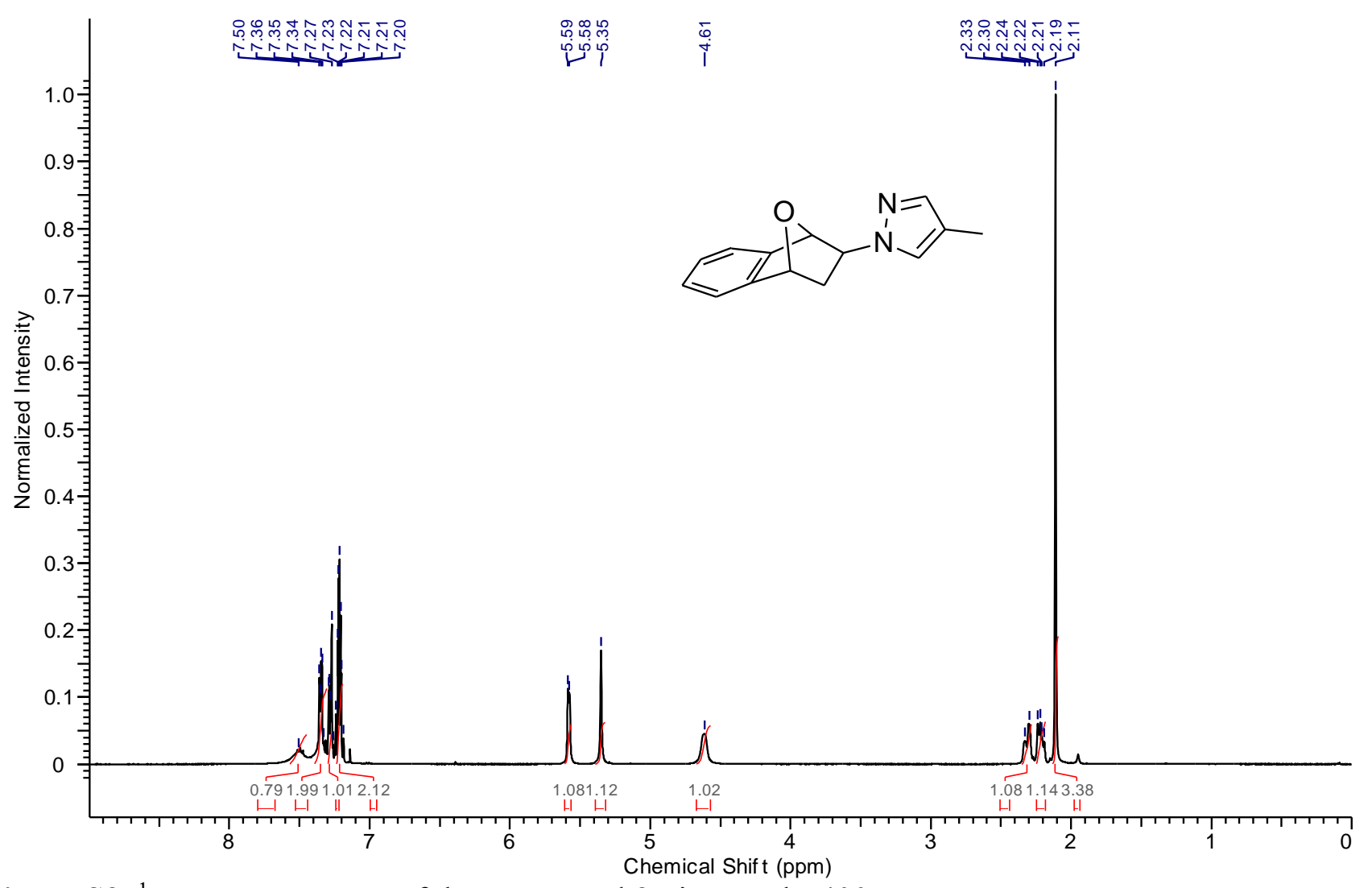

Figure S3. ${ }^{1} \mathrm{H}$ NMR spectrum of the compound $\mathbf{3 b}$ in $\mathrm{CDCl}_{3}, 400 \mathrm{MHz}$

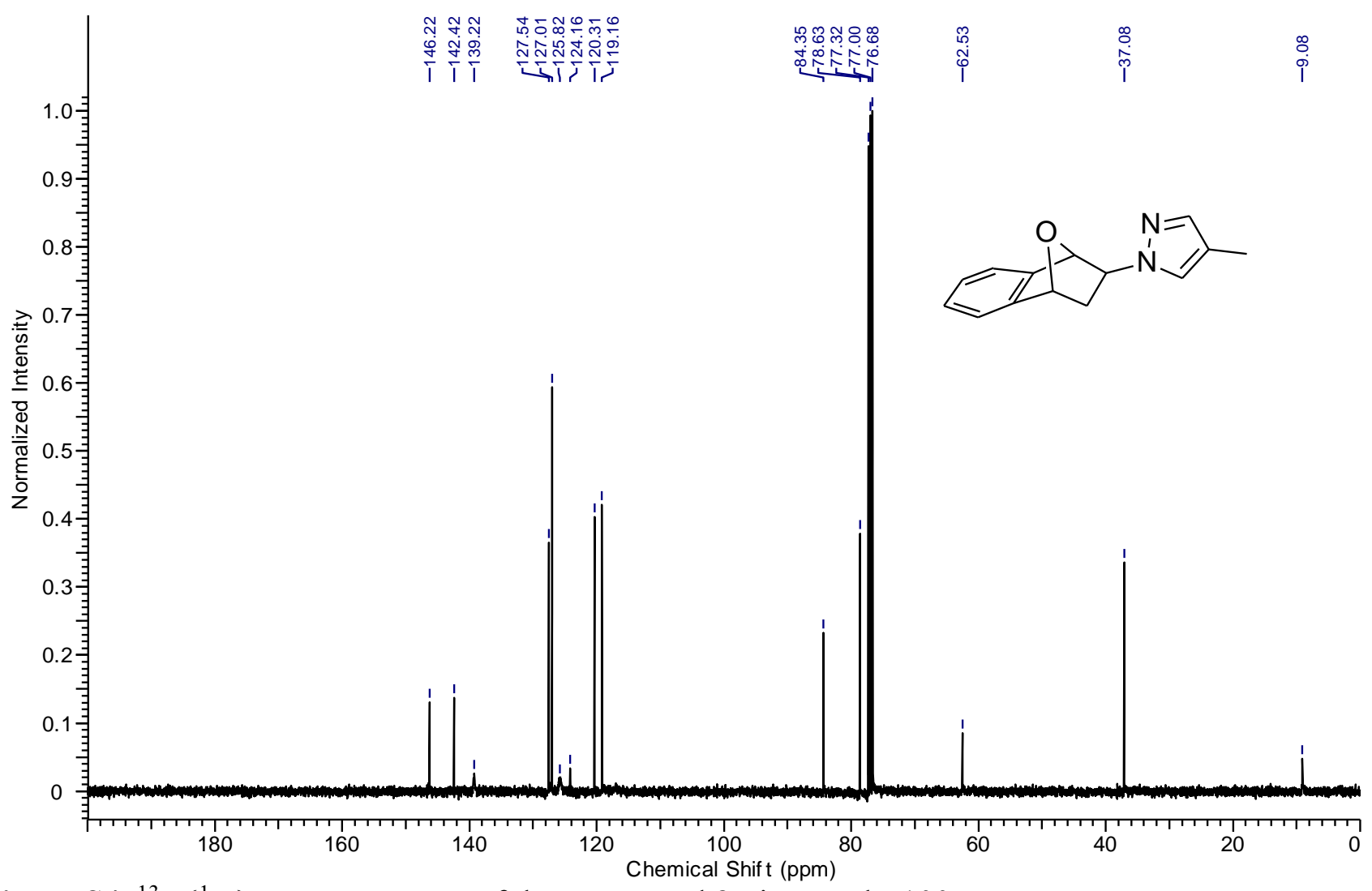

Figure S4. ${ }^{13} \mathrm{C}\left\{{ }^{1} \mathrm{H}\right\}$ NMR spectrum of the compound $3 \mathbf{b}$ in $\mathrm{CDCl}_{3}, 100 \mathrm{MHz}$

SB 


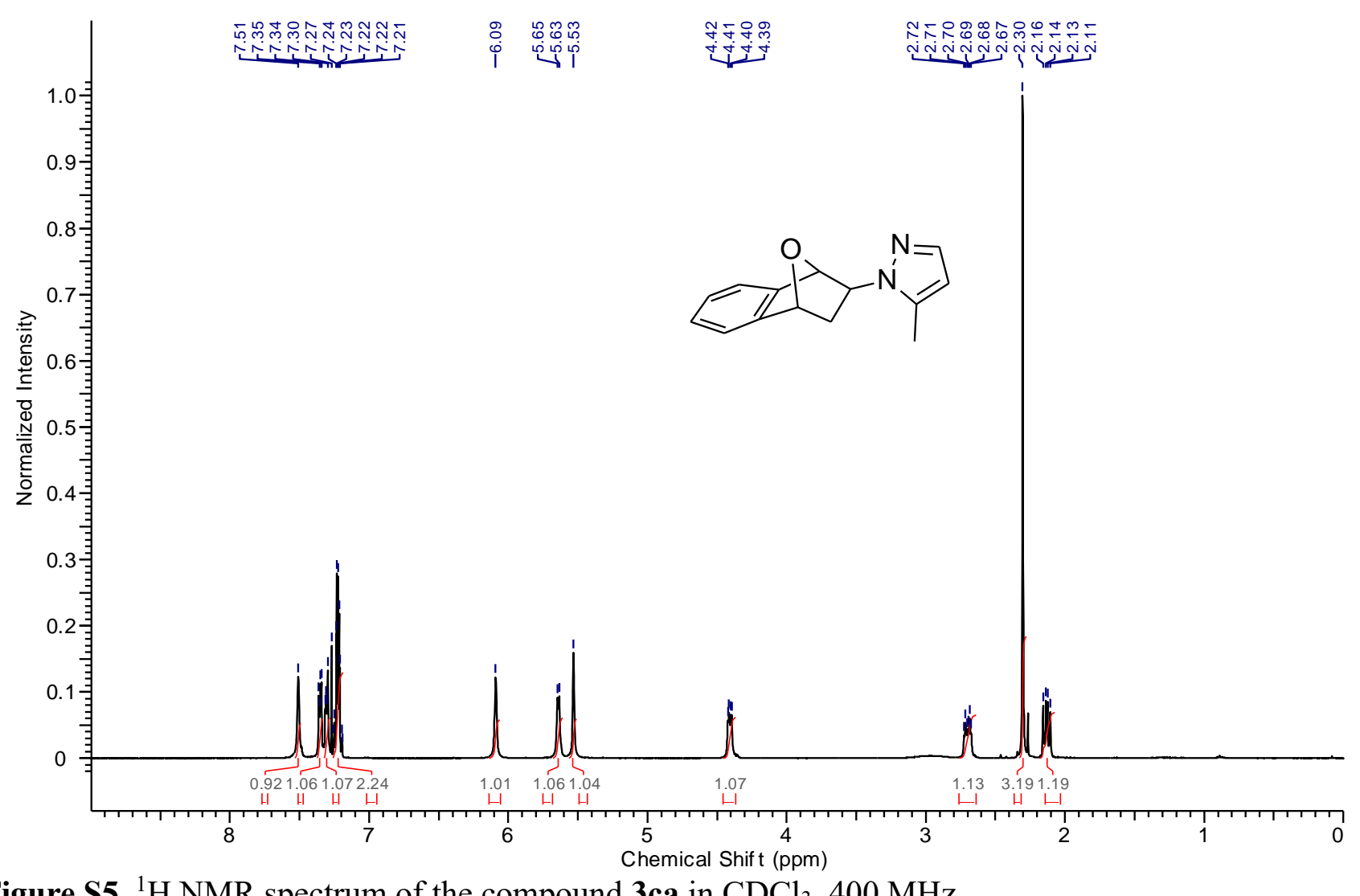

Figure S5. ${ }^{1} \mathrm{H}$ NMR spectrum of the compound $3 \mathbf{c a}$ in $\mathrm{CDCl}_{3}, 400 \mathrm{MHz}$

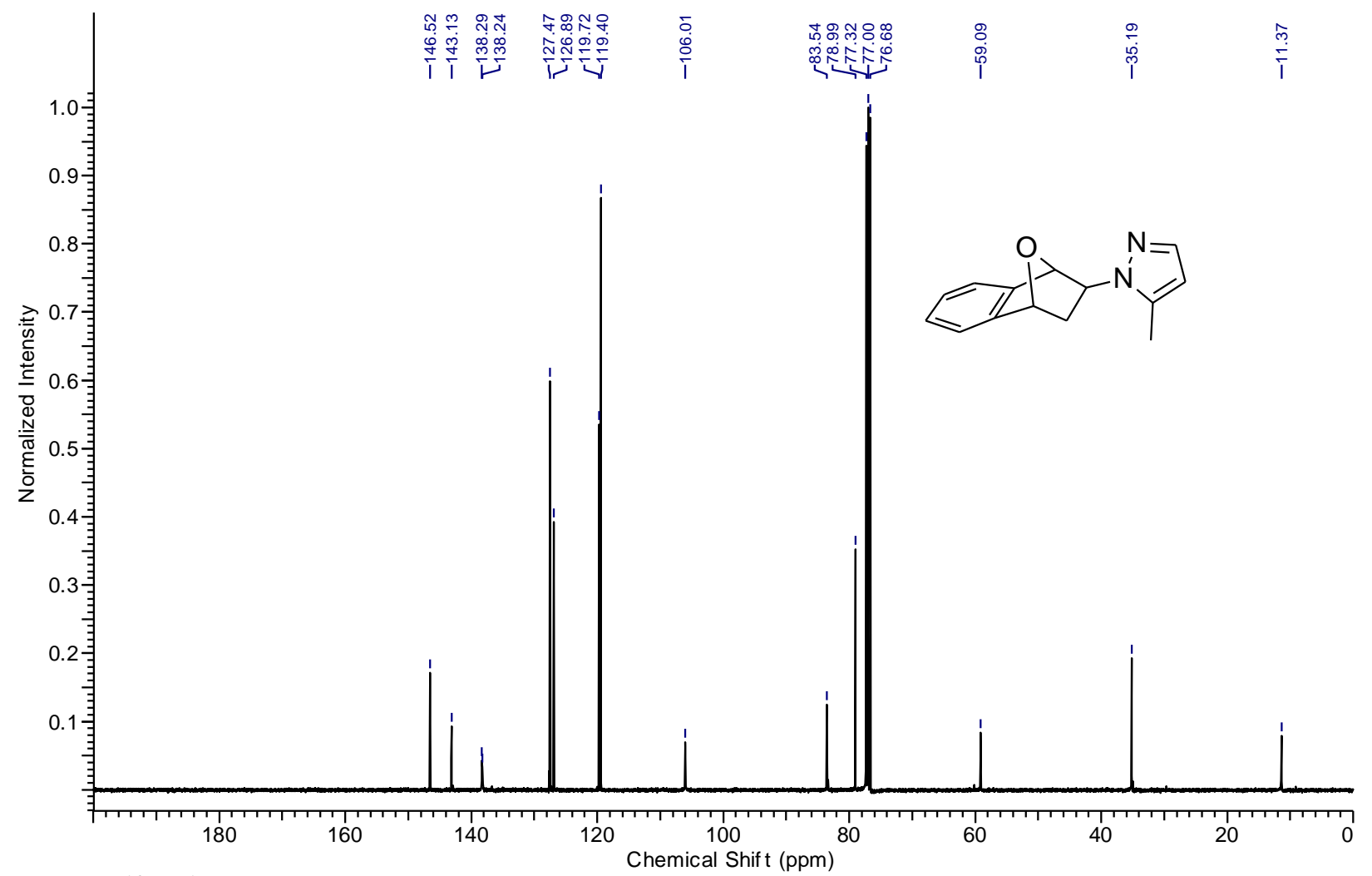

Figure S6. ${ }^{13} \mathrm{C}\left\{{ }^{1} \mathrm{H}\right\} \mathrm{NMR}$ spectrum of the compound 3 ca in $\mathrm{CDCl}_{3}, 100 \mathrm{MHz}$

SH 


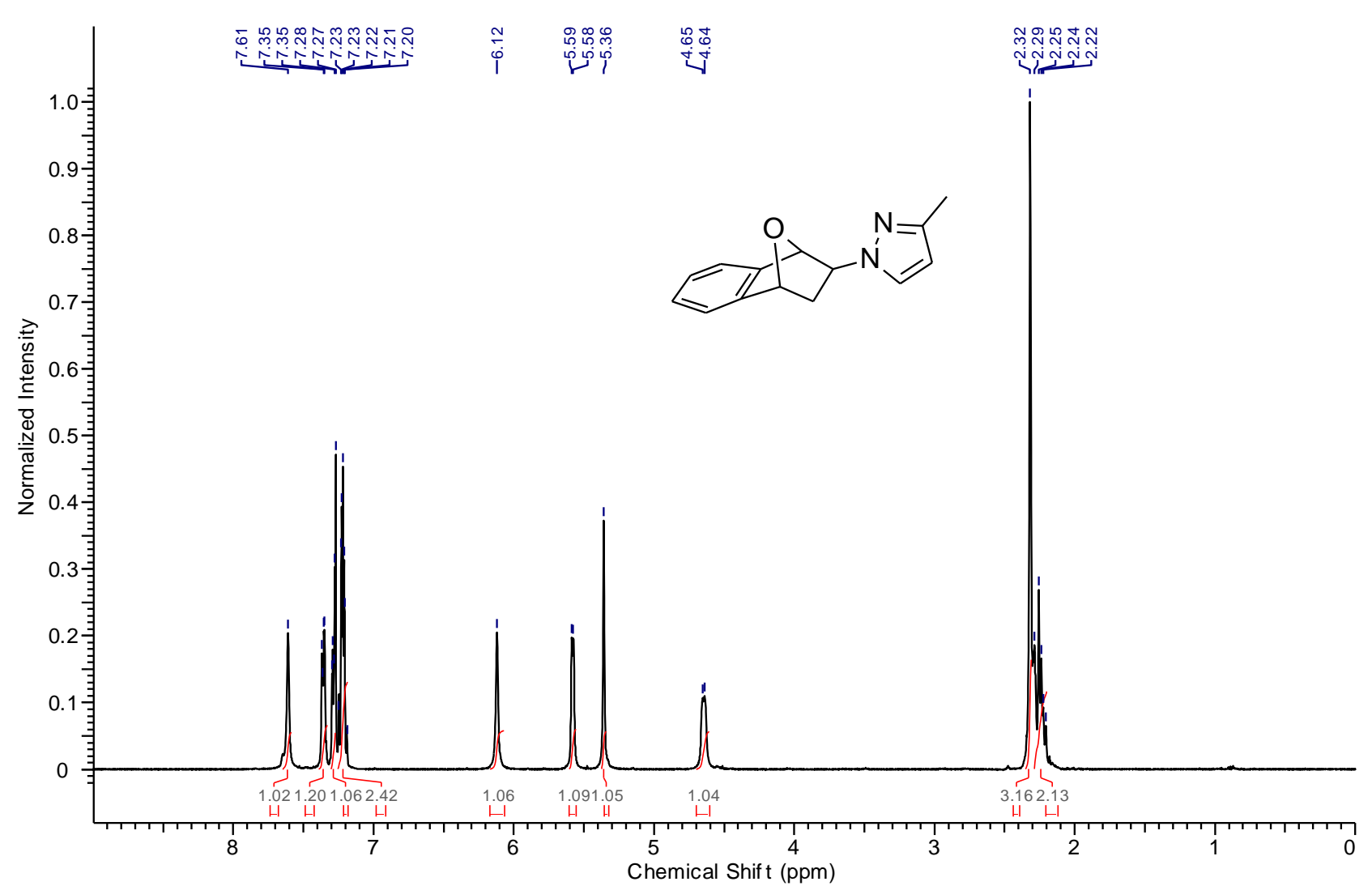

Figure S7. ${ }^{1} \mathrm{H}$ NMR spectrum of the compound $\mathbf{3 c b}$ in $\mathrm{CDCl}_{3}, 400 \mathrm{MHz}$

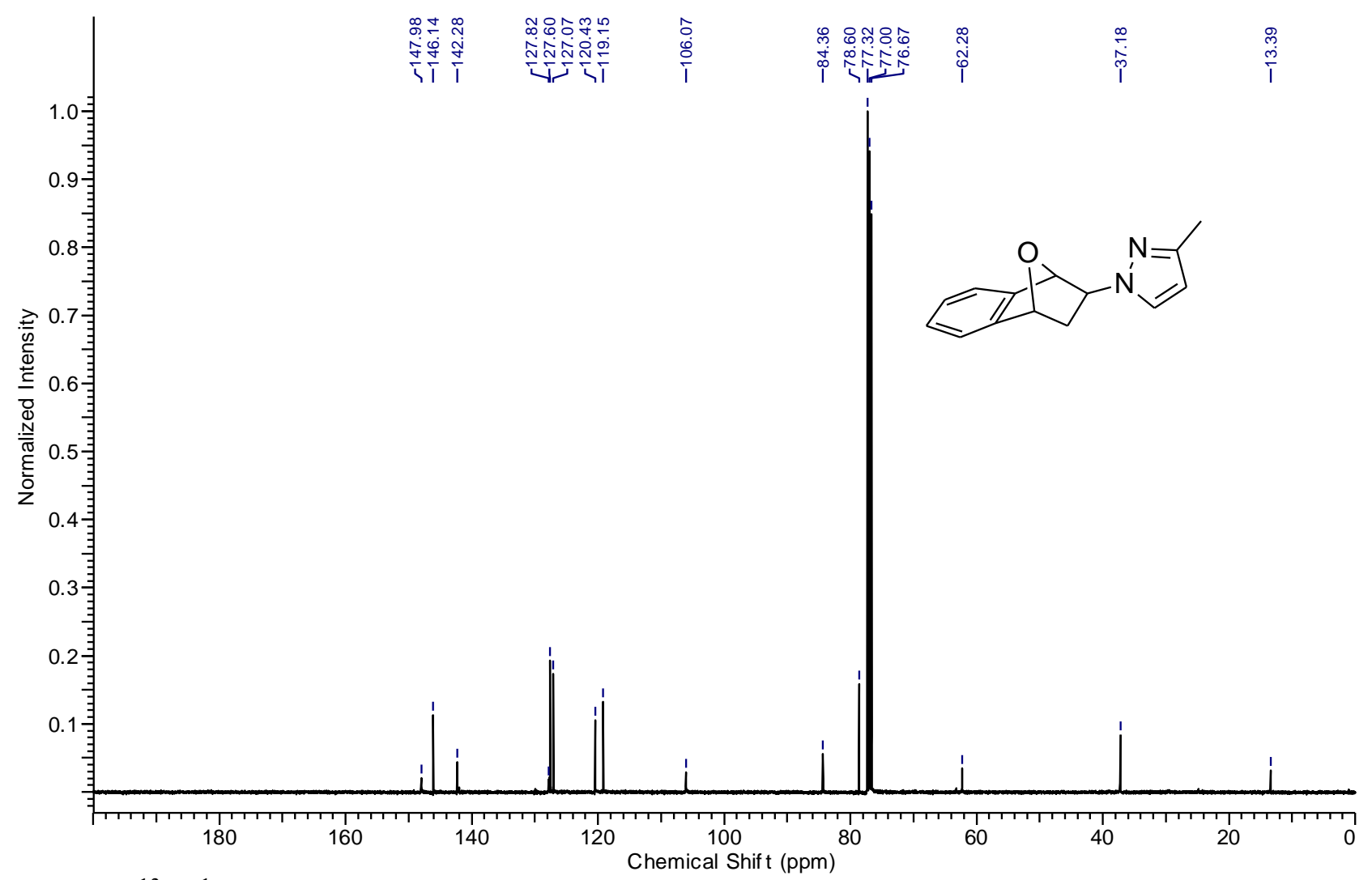

Figure S8. ${ }^{13} \mathrm{C}\left\{{ }^{1} \mathrm{H}\right\}$ NMR spectrum of the compound $\mathbf{3 c b}$ in $\mathrm{CDCl}_{3}, 100 \mathrm{MHz}$

SF 


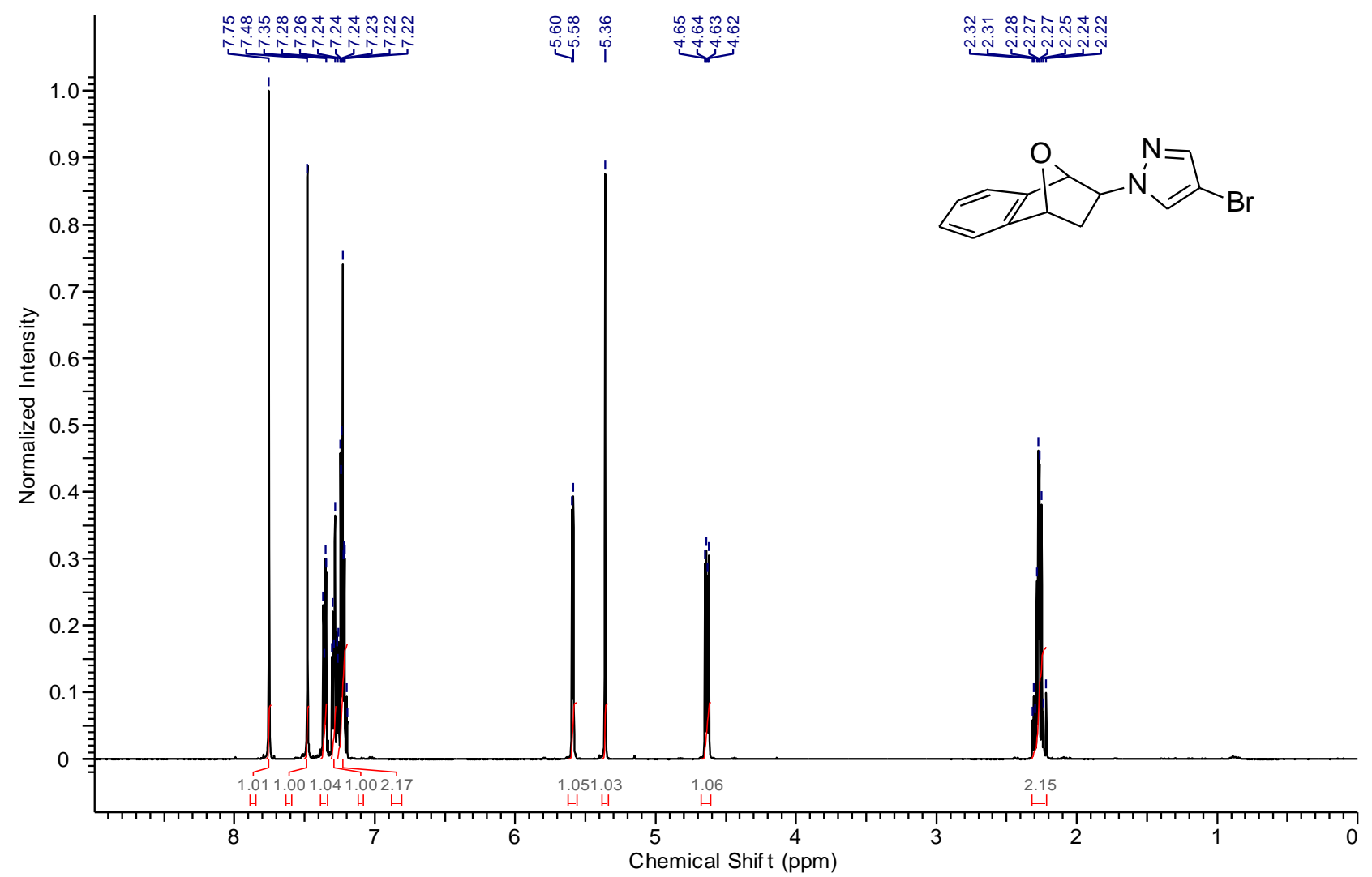

Figure S9. ${ }^{1} \mathrm{H}$ NMR spectrum of the compound $\mathbf{3 d}$ in $\mathrm{CDCl}_{3}, 400 \mathrm{MHz}$

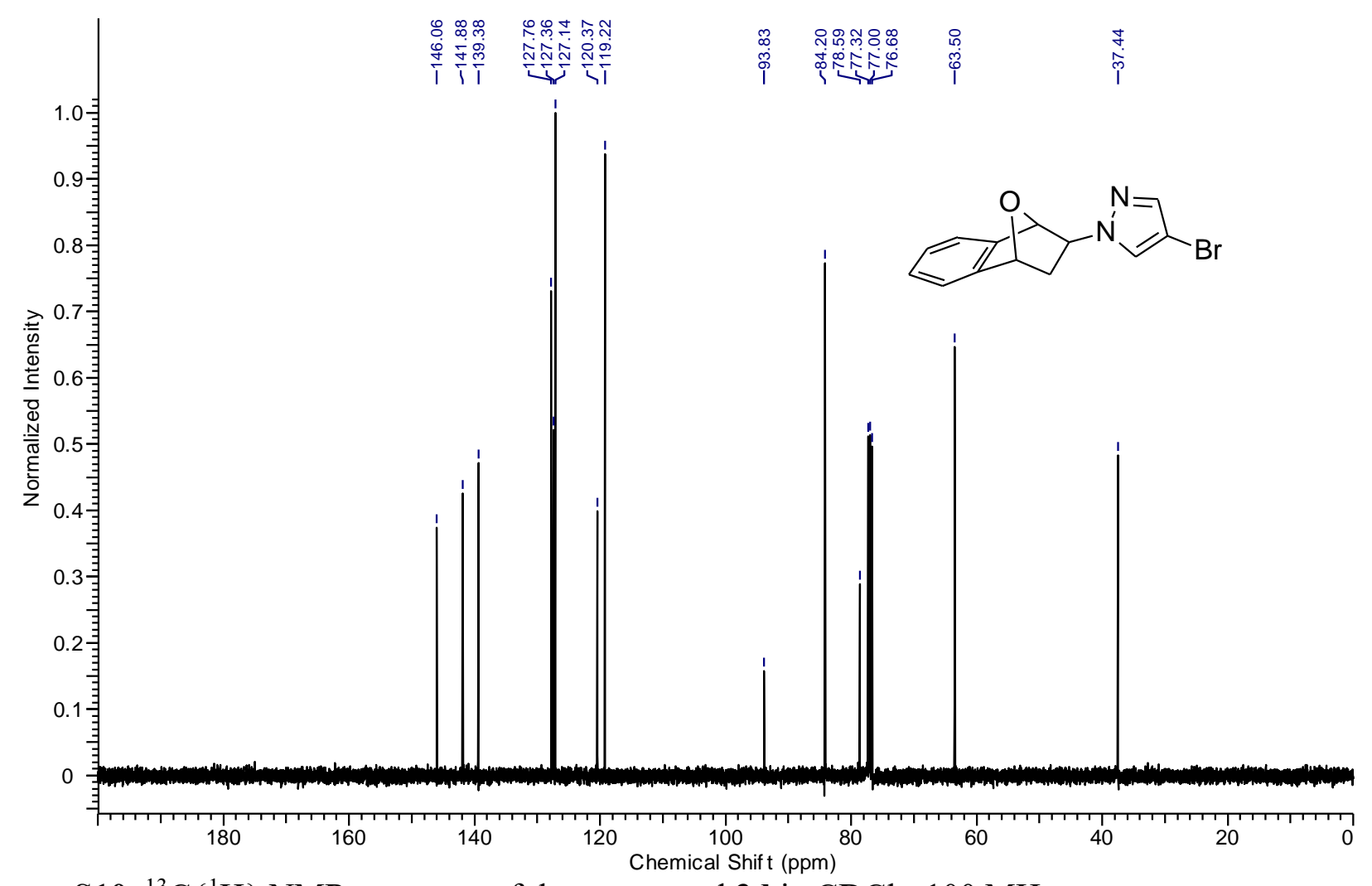

Figure S10. ${ }^{13} \mathrm{C}\left\{{ }^{1} \mathrm{H}\right\}$ NMR spectrum of the compound $\mathbf{3 d}$ in $\mathrm{CDCl}_{3}, 100 \mathrm{MHz}$ 


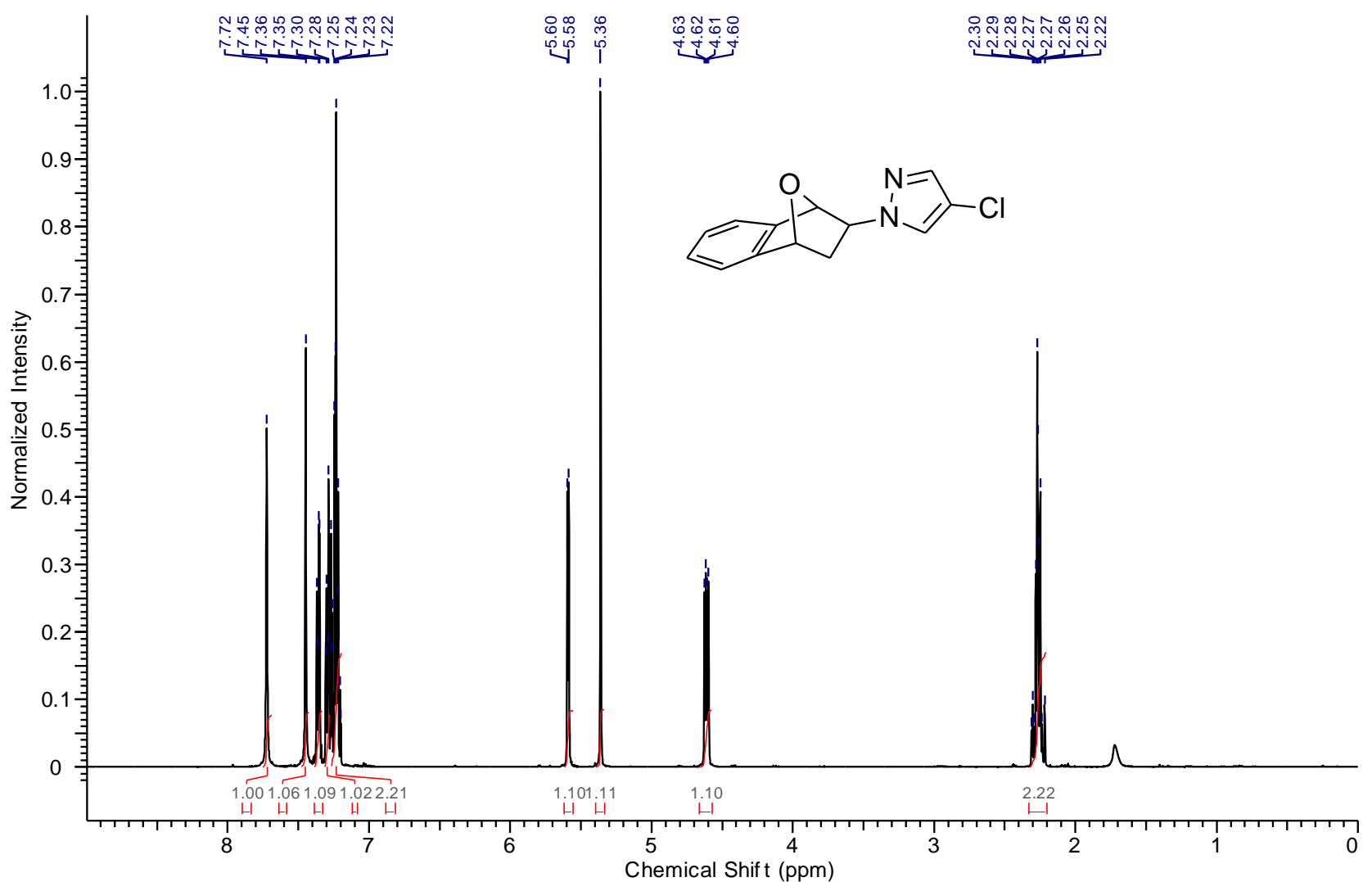

Figure S11. ${ }^{1} \mathrm{H}$ NMR spectrum of the compound $\mathbf{3 e}$ in $\mathrm{CDCl}_{3}, 400 \mathrm{MHz}$

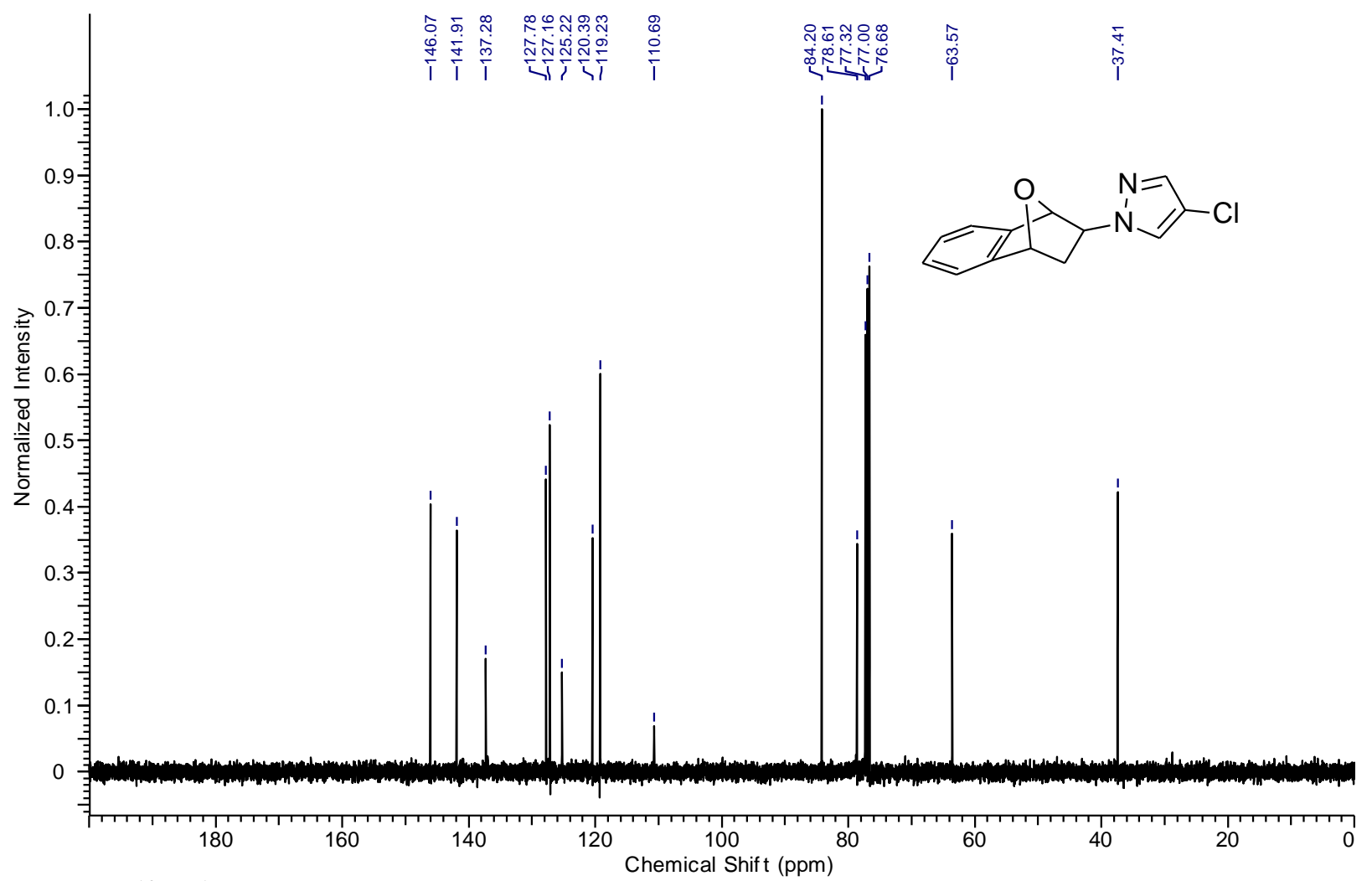

Figure S12. ${ }^{13} \mathrm{C}\left\{{ }^{1} \mathrm{H}\right\}$ NMR spectrum of the compound $3 \mathbf{e}$ in $\mathrm{CDCl}_{3}, 100 \mathrm{MHz}$ 


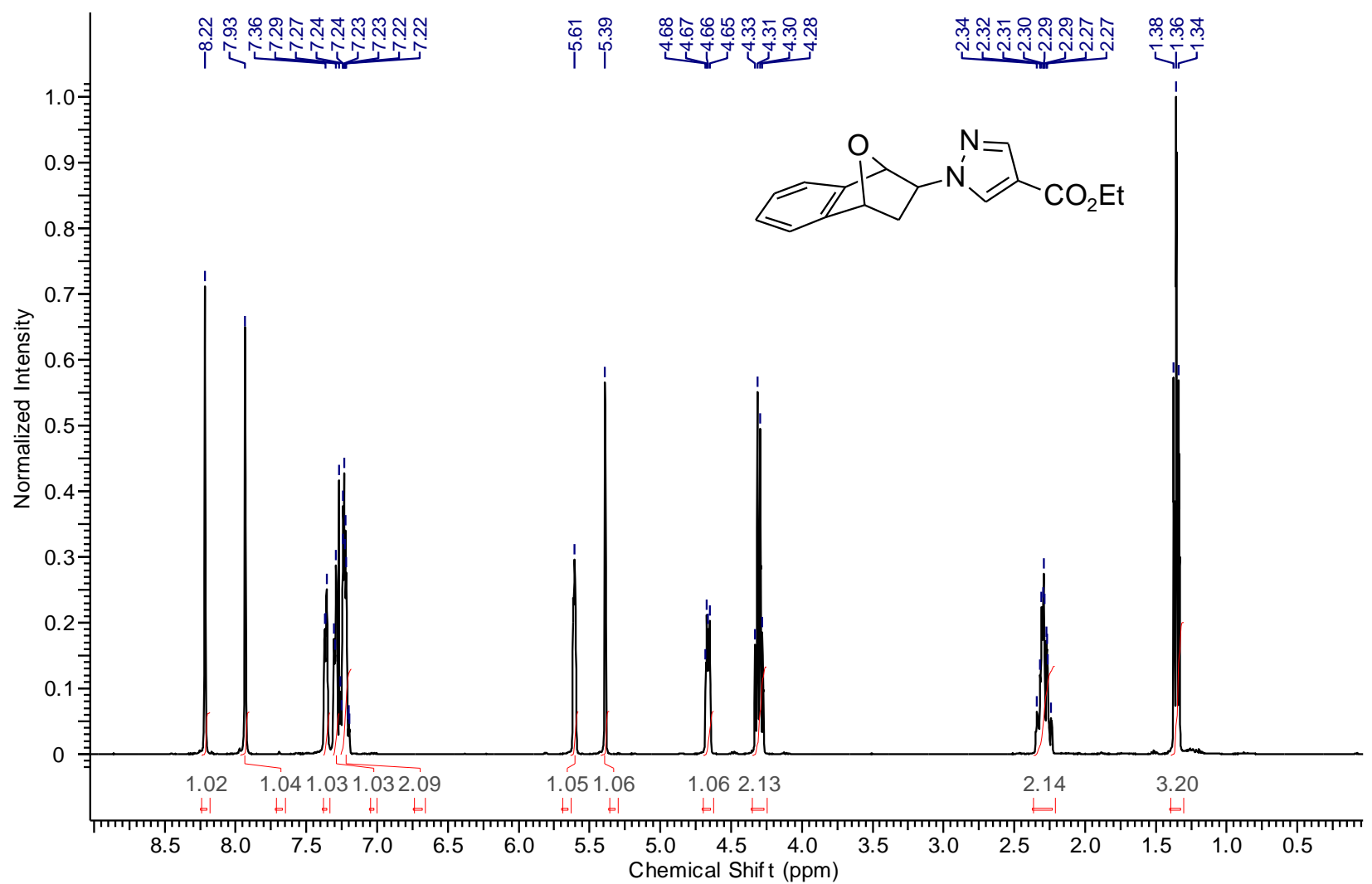

Figure S13. ${ }^{1} \mathrm{H}$ NMR spectrum of the compound $\mathbf{3 f}$ in $\mathrm{CDCl}_{3}, 400 \mathrm{MHz}$

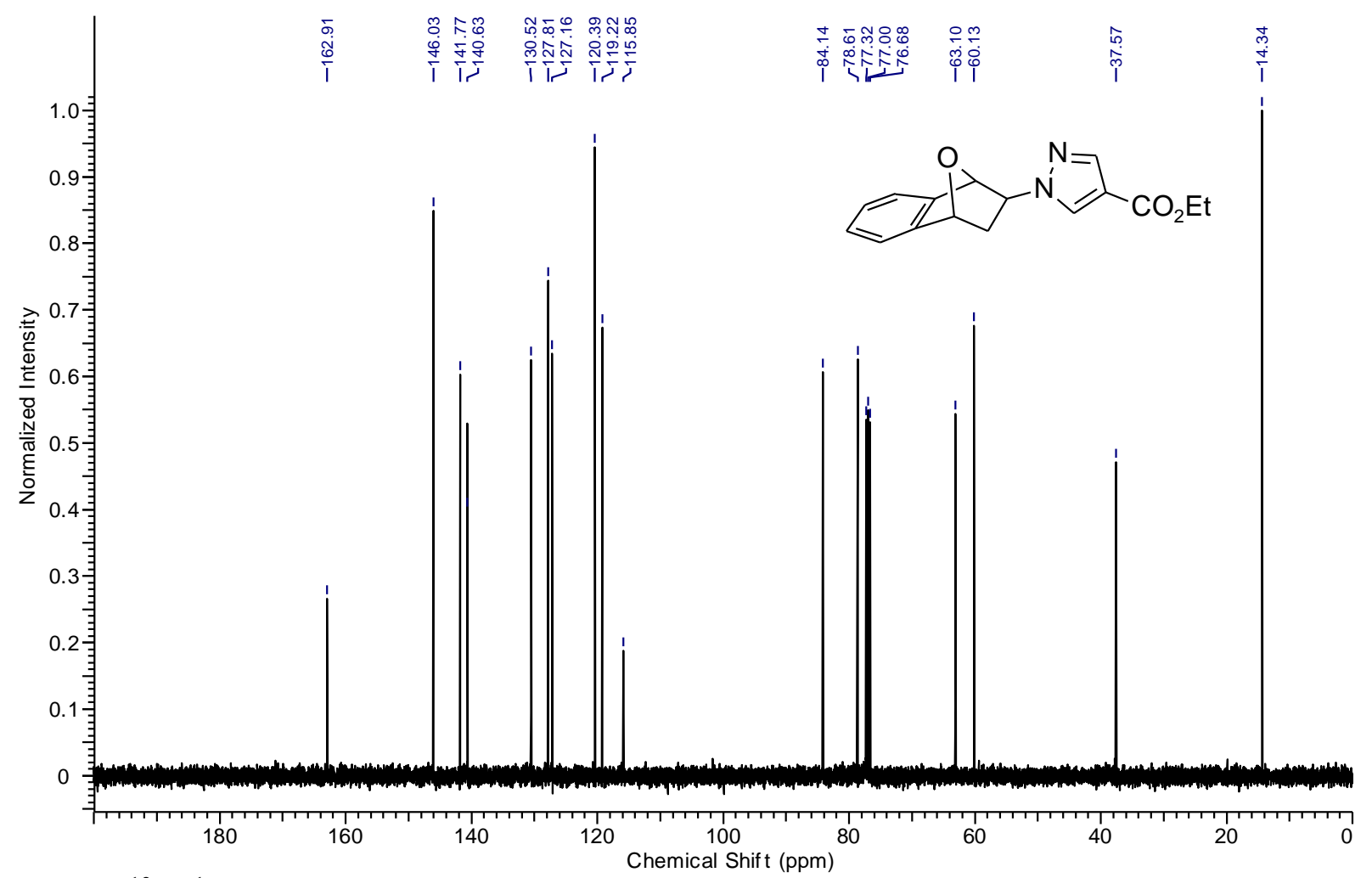

Figure S14. ${ }^{13} \mathrm{C}\left\{{ }^{1} \mathrm{H}\right\}$ NMR spectrum of the compound $\mathbf{3 f}$ in $\mathrm{CDCl}_{3}, 100 \mathrm{MHz}$ 


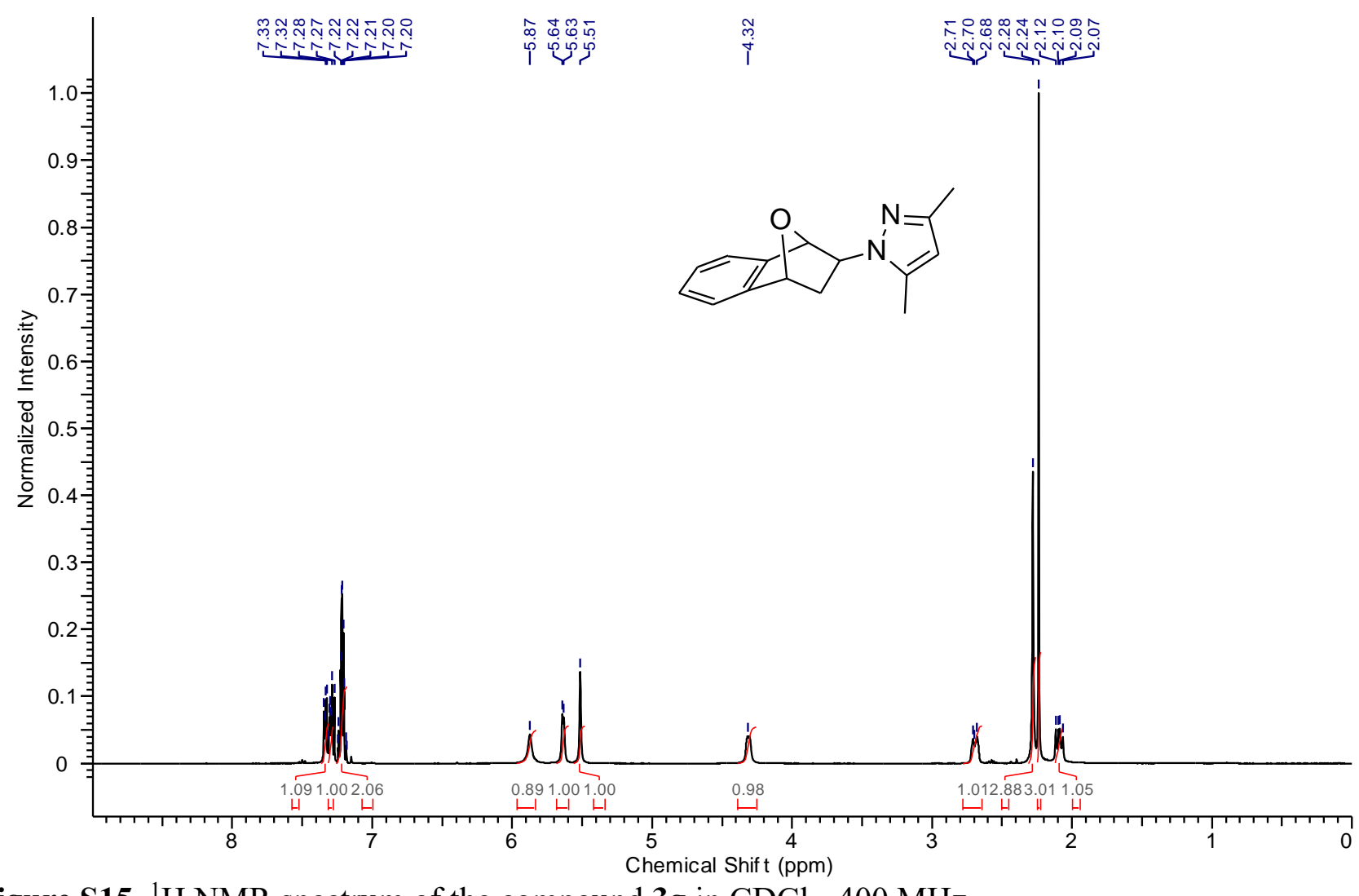

Figure S15. ${ }^{1} \mathrm{H}$ NMR spectrum of the compound $\mathbf{3 g}$ in $\mathrm{CDCl}_{3}, 400 \mathrm{MHz}$

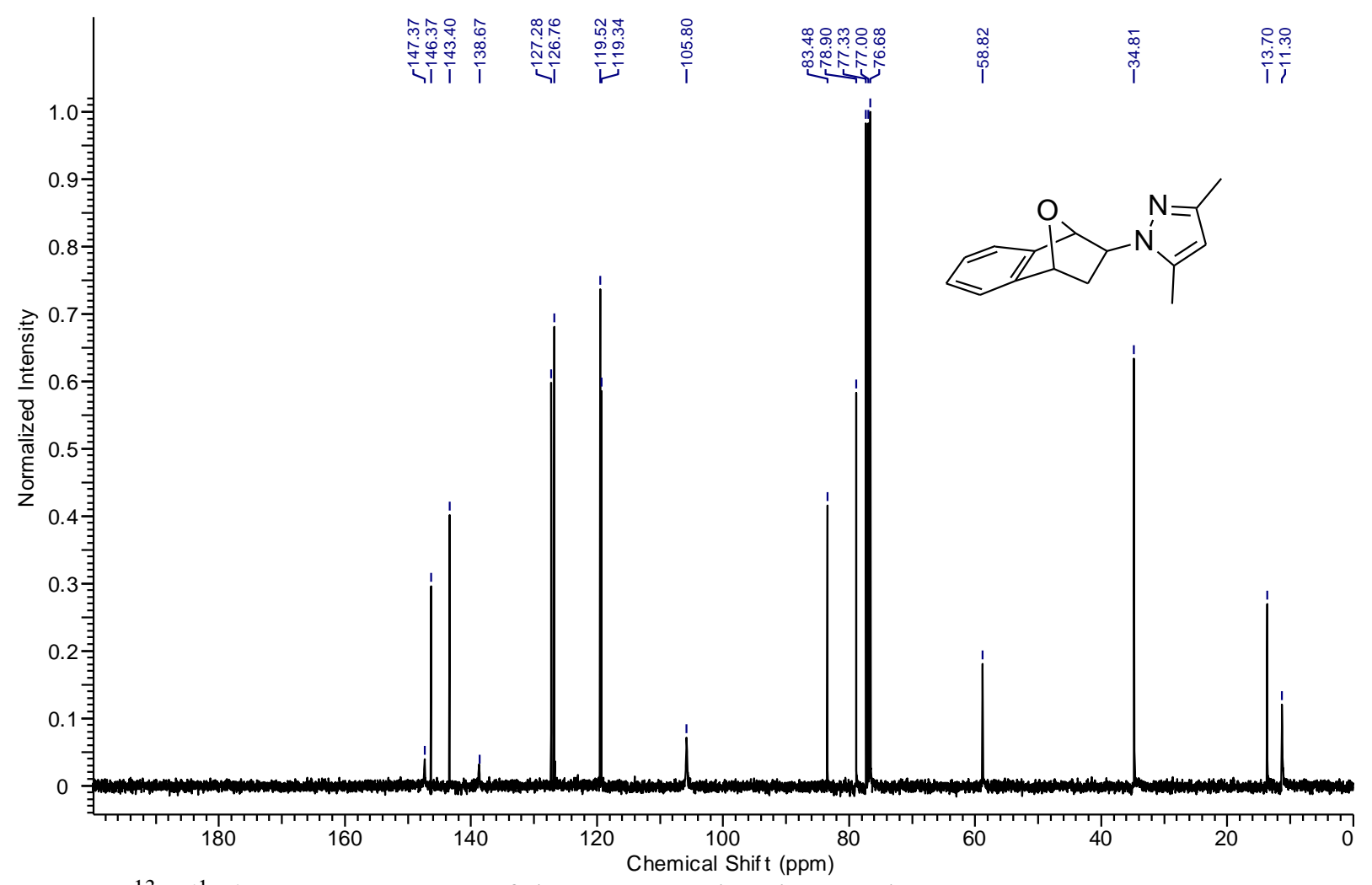

Figure S16. ${ }^{13} \mathrm{C}\left\{{ }^{1} \mathrm{H}\right\} \mathrm{NMR}$ spectrum of the compound $3 \mathrm{~g}$ in $\mathrm{CDCl}_{3}, 100 \mathrm{MHz}$

Sq 


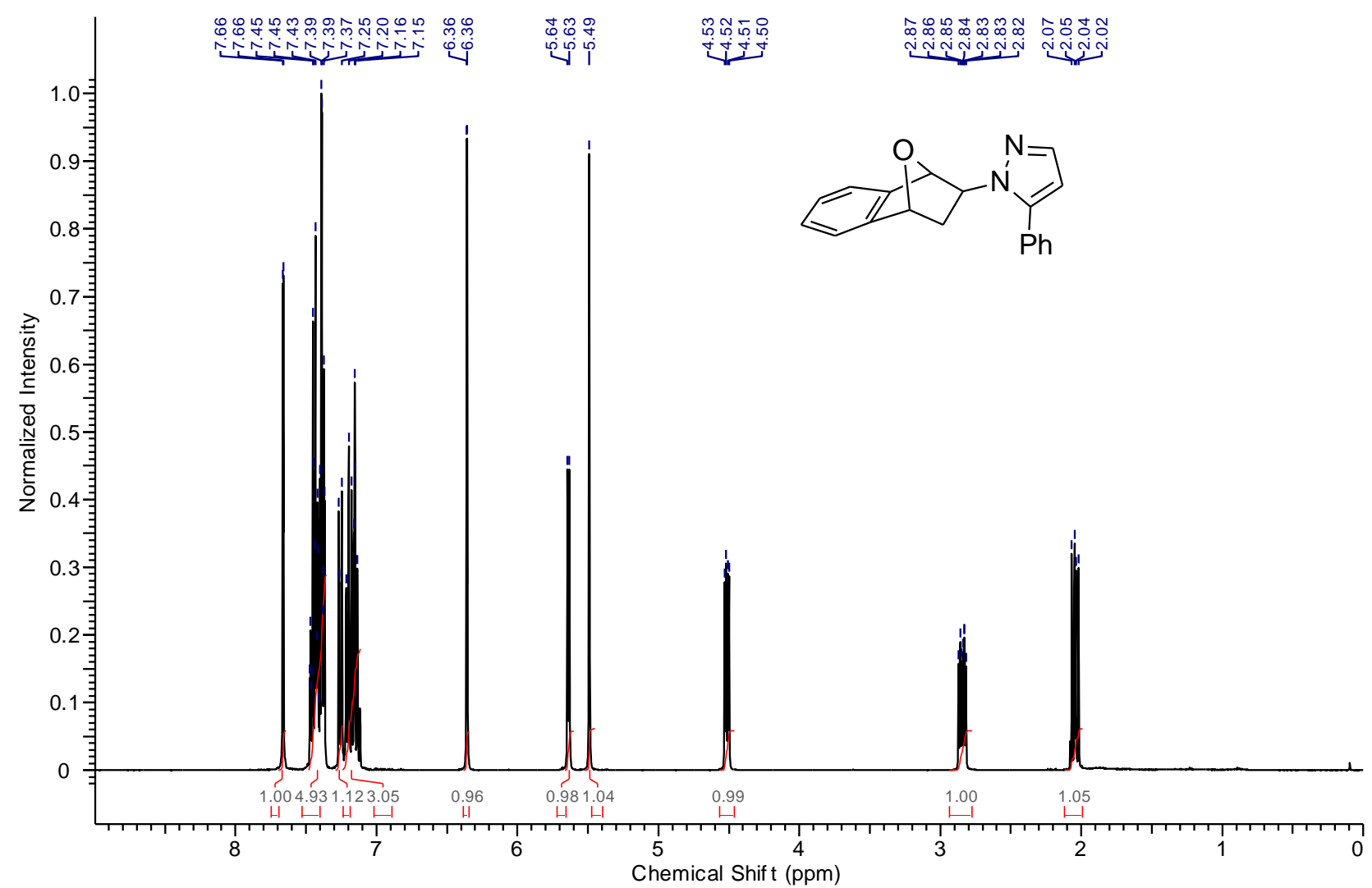

Figure S17. ${ }^{1} \mathrm{H}$ NMR spectrum of the compound $\mathbf{3 h}$ in $\mathrm{CDCl}_{3}, 400 \mathrm{MHz}$

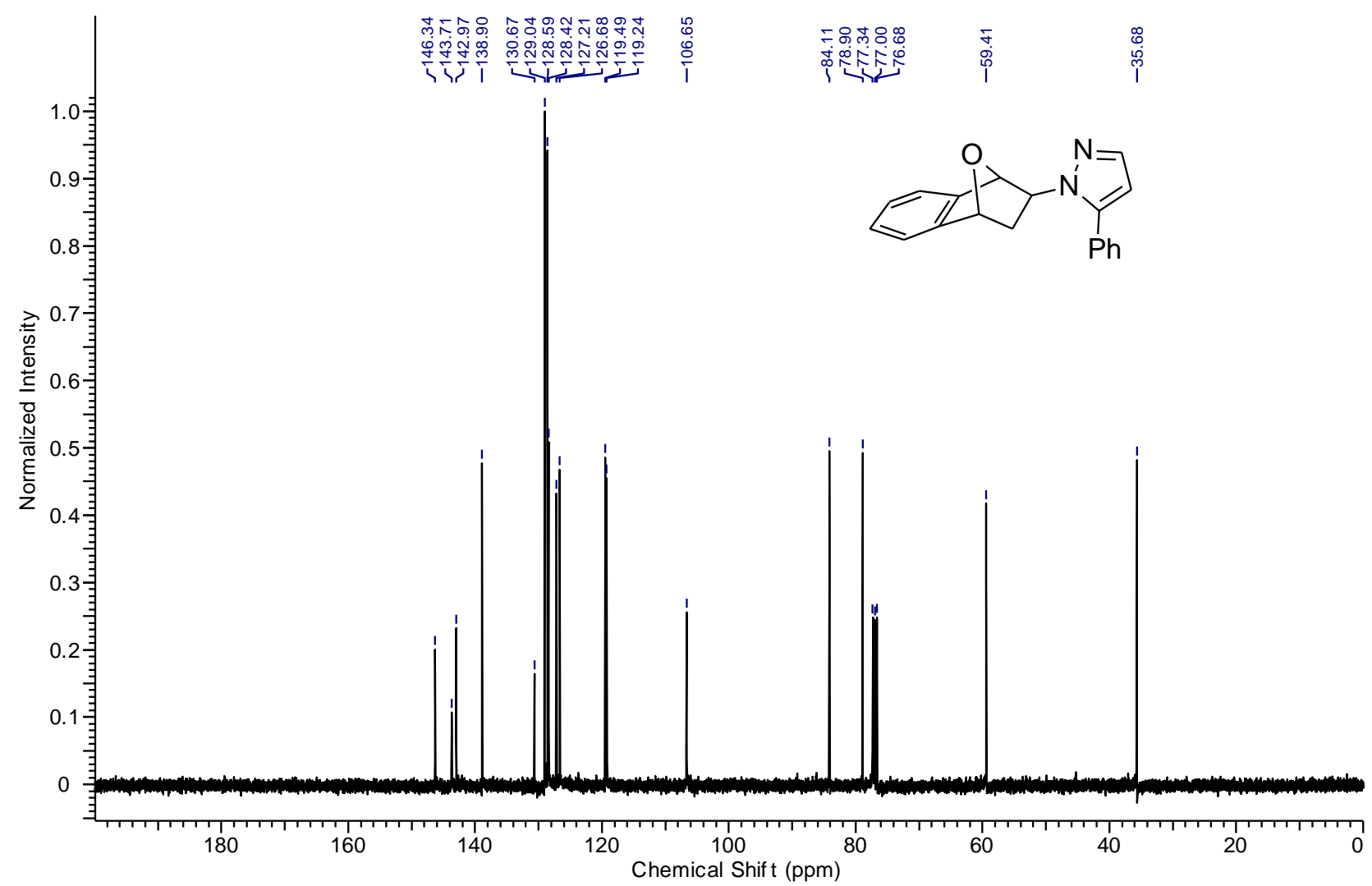

Figure S18. ${ }^{13} \mathrm{C}\left\{{ }^{1} \mathrm{H}\right\}$ NMR spectrum of the compound $\mathbf{3 h}$ in $\mathrm{CDCl}_{3}, 100 \mathrm{MHz}$

$\mathrm{S} 10$ 


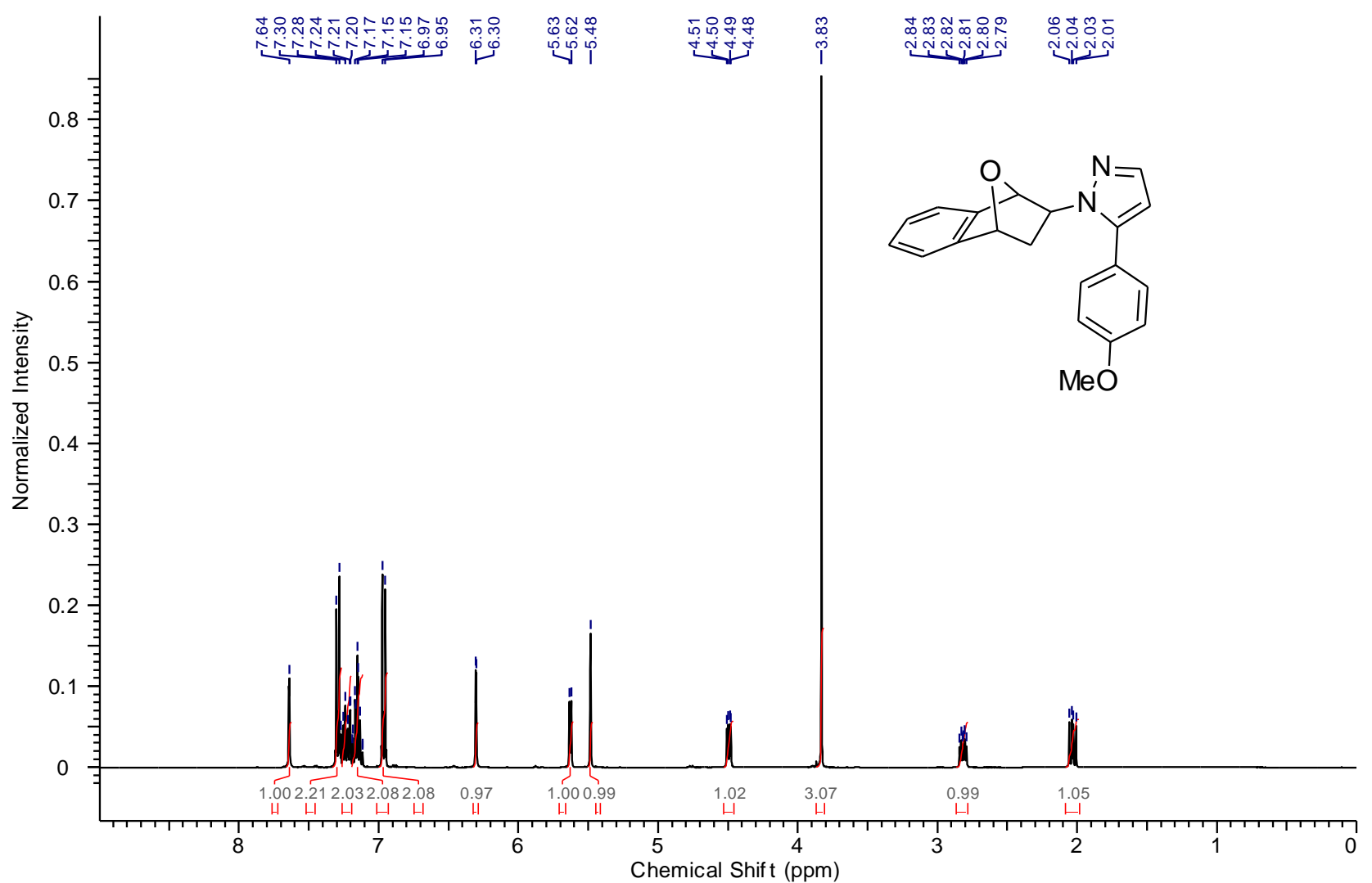

Figure S19. ${ }^{1} \mathrm{H}$ NMR spectrum of the compound $3 \mathbf{i}$ in $\mathrm{CDCl}_{3}, 400 \mathrm{MHz}$

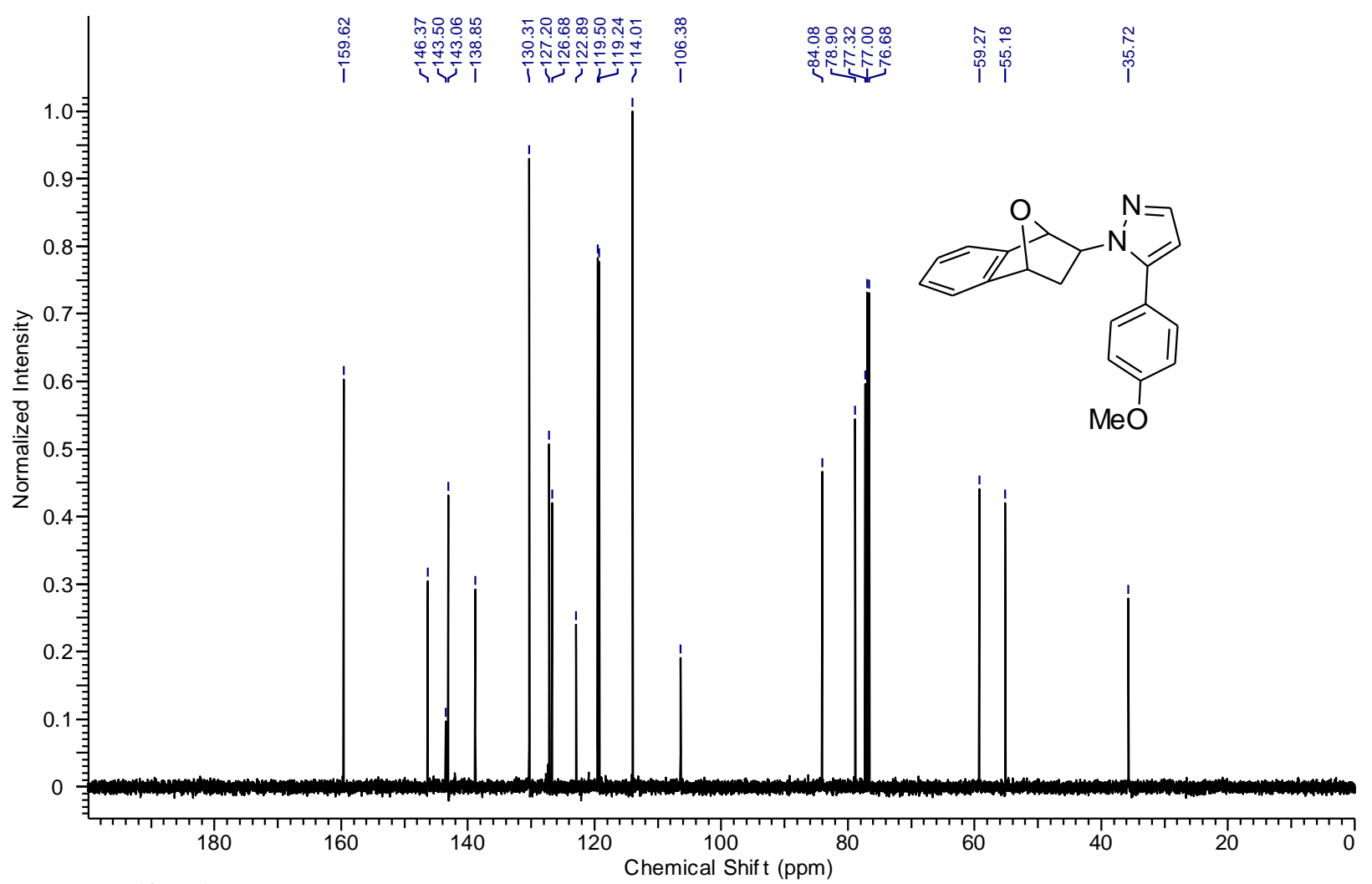

Figure S20. ${ }^{13} \mathrm{C}\left\{{ }^{1} \mathrm{H}\right\} \mathrm{NMR}$ spectrum of the compound $\mathbf{3 i}$ in $\mathrm{CDCl}_{3}, 100 \mathrm{MHz}$ 


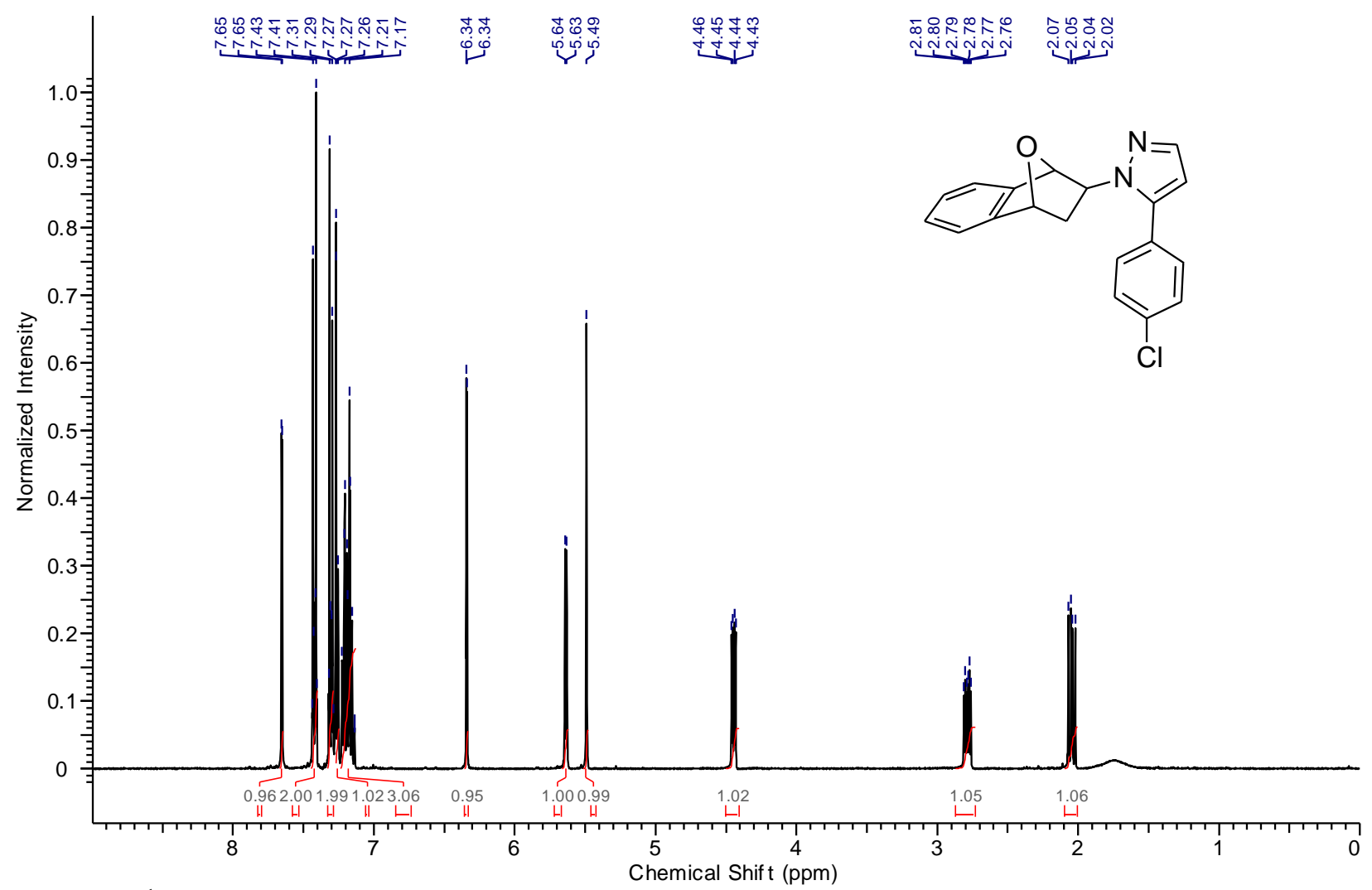

Figure S21. ${ }^{1} \mathrm{H}$ NMR spectrum of the compound $\mathbf{3 j}$ in $\mathrm{CDCl}_{3}, 400 \mathrm{MHz}$

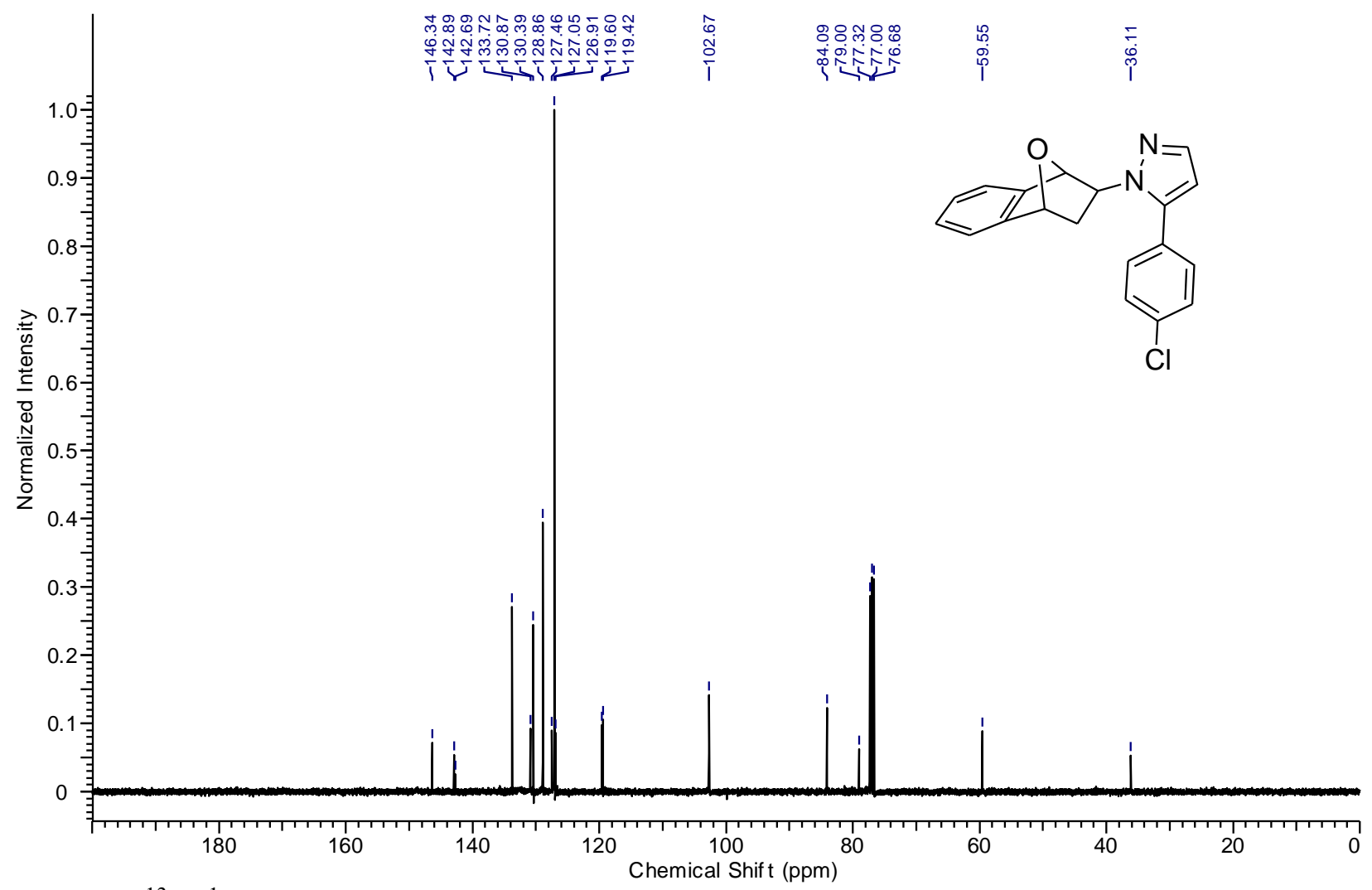

Figure S22. ${ }^{13} \mathrm{C}\left\{{ }^{1} \mathrm{H}\right\}$ NMR spectrum of the compound $\mathbf{3} \mathbf{j}$ in $\mathrm{CDCl}_{3}, 100 \mathrm{MHz}$ 


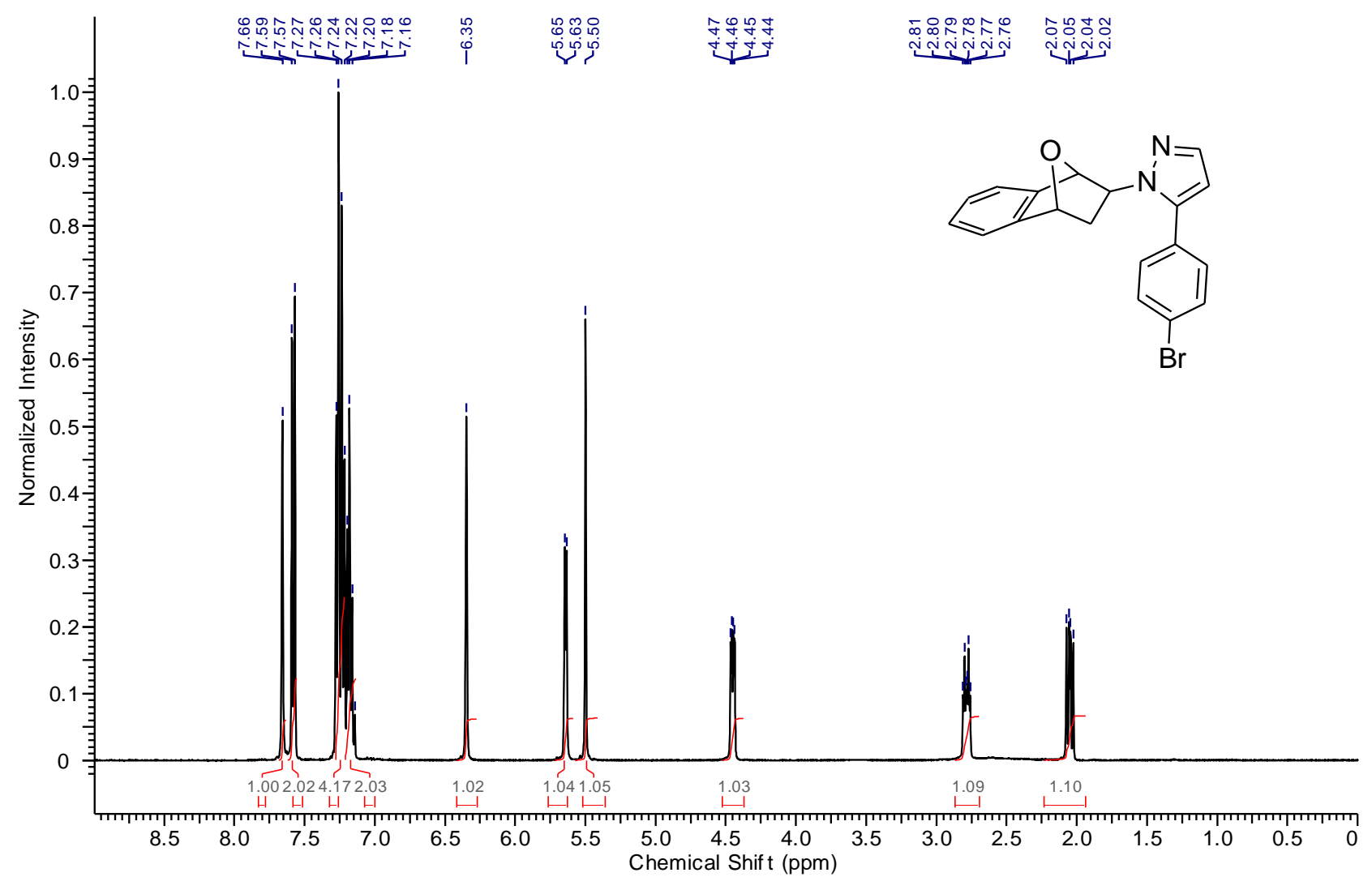

Figure S23. ${ }^{1} \mathrm{H}$ NMR spectrum of the compound 3k in $\mathrm{CDCl}_{3}, 400 \mathrm{MHz}$

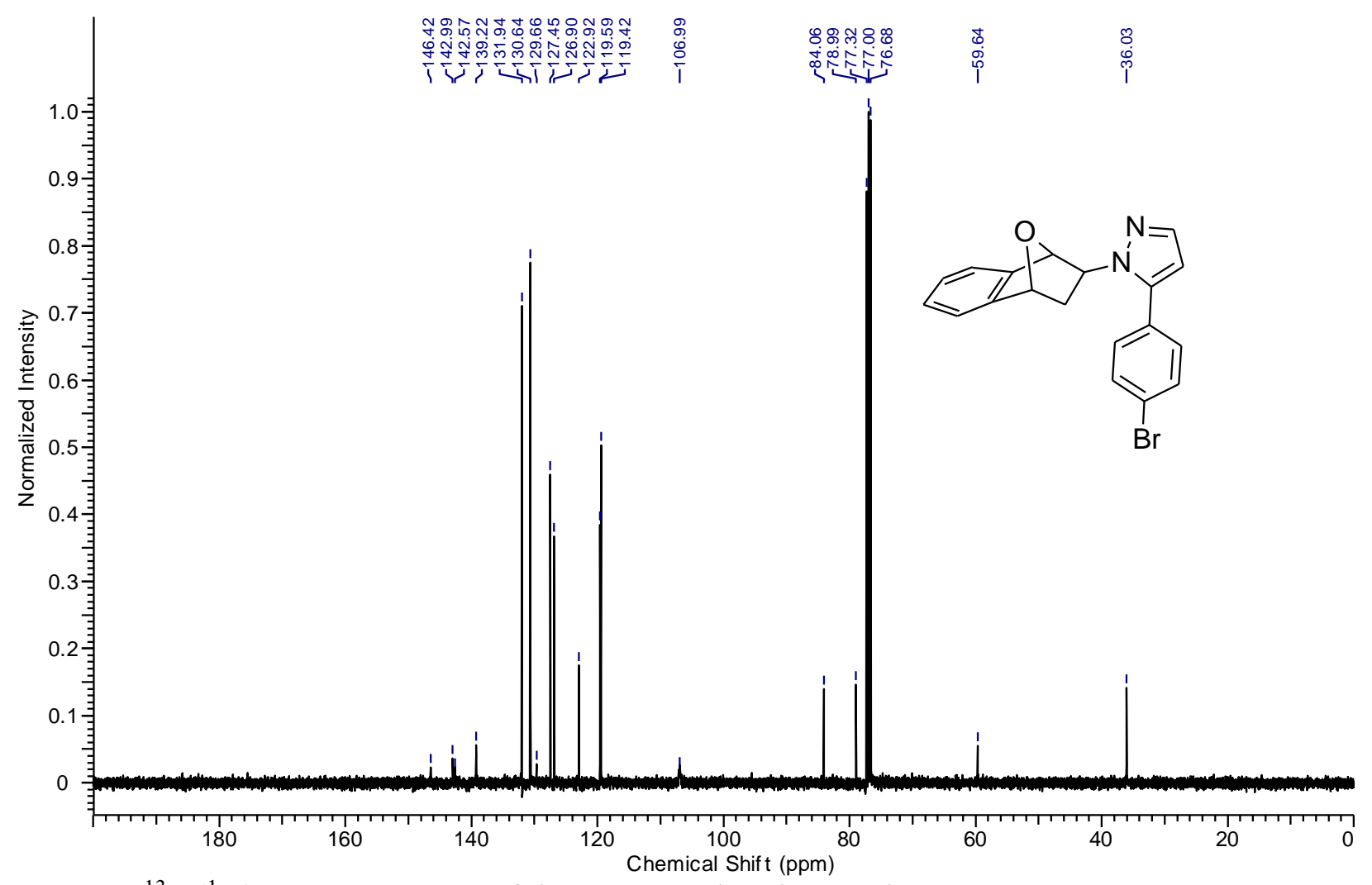

Figure S24. ${ }^{13} \mathrm{C}\left\{{ }^{1} \mathrm{H}\right\}$ NMR spectrum of the compound $\mathbf{3 k}$ in $\mathrm{CDCl}_{3}, 100 \mathrm{MHz}$ 


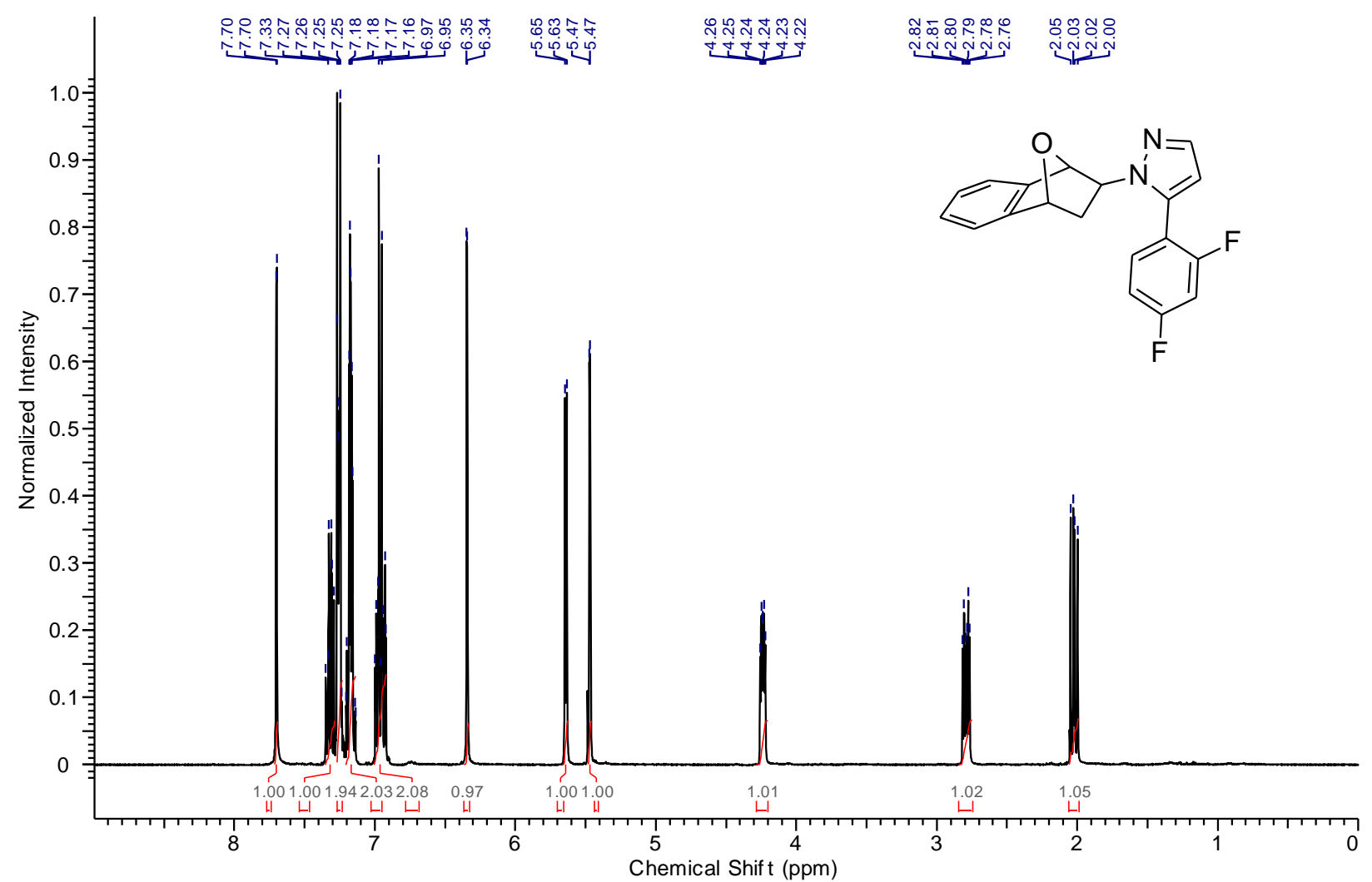

Figure S25. ${ }^{1} \mathrm{H}$ NMR spectrum of the compound 31 in $\mathrm{CDCl}_{3}, 400 \mathrm{MHz}$

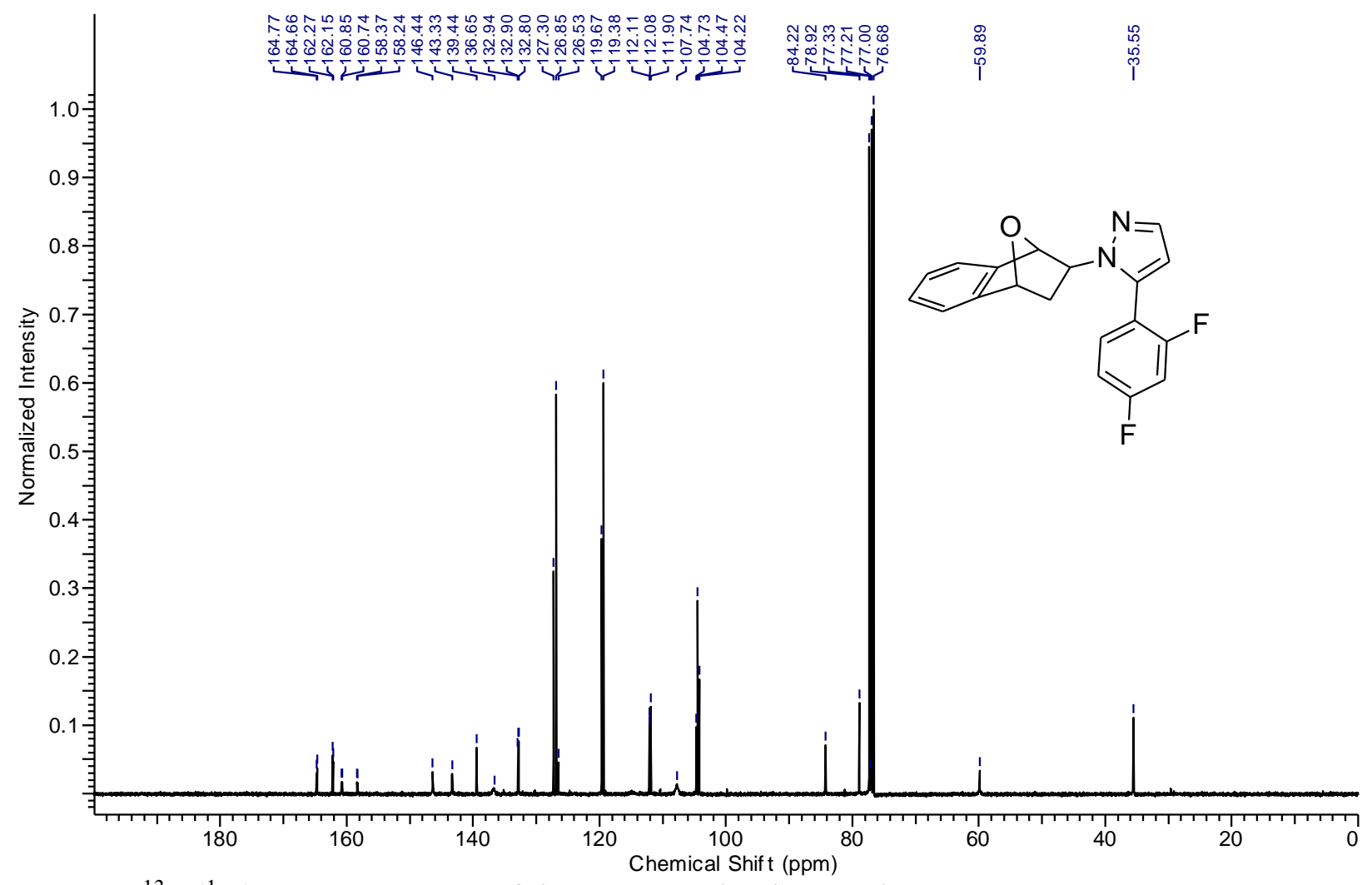

Figure S26. ${ }^{13} \mathrm{C}\left\{{ }^{1} \mathrm{H}\right\}$ NMR spectrum of the compound 31 in $\mathrm{CDCl}_{3}, 100 \mathrm{MHz}$ 


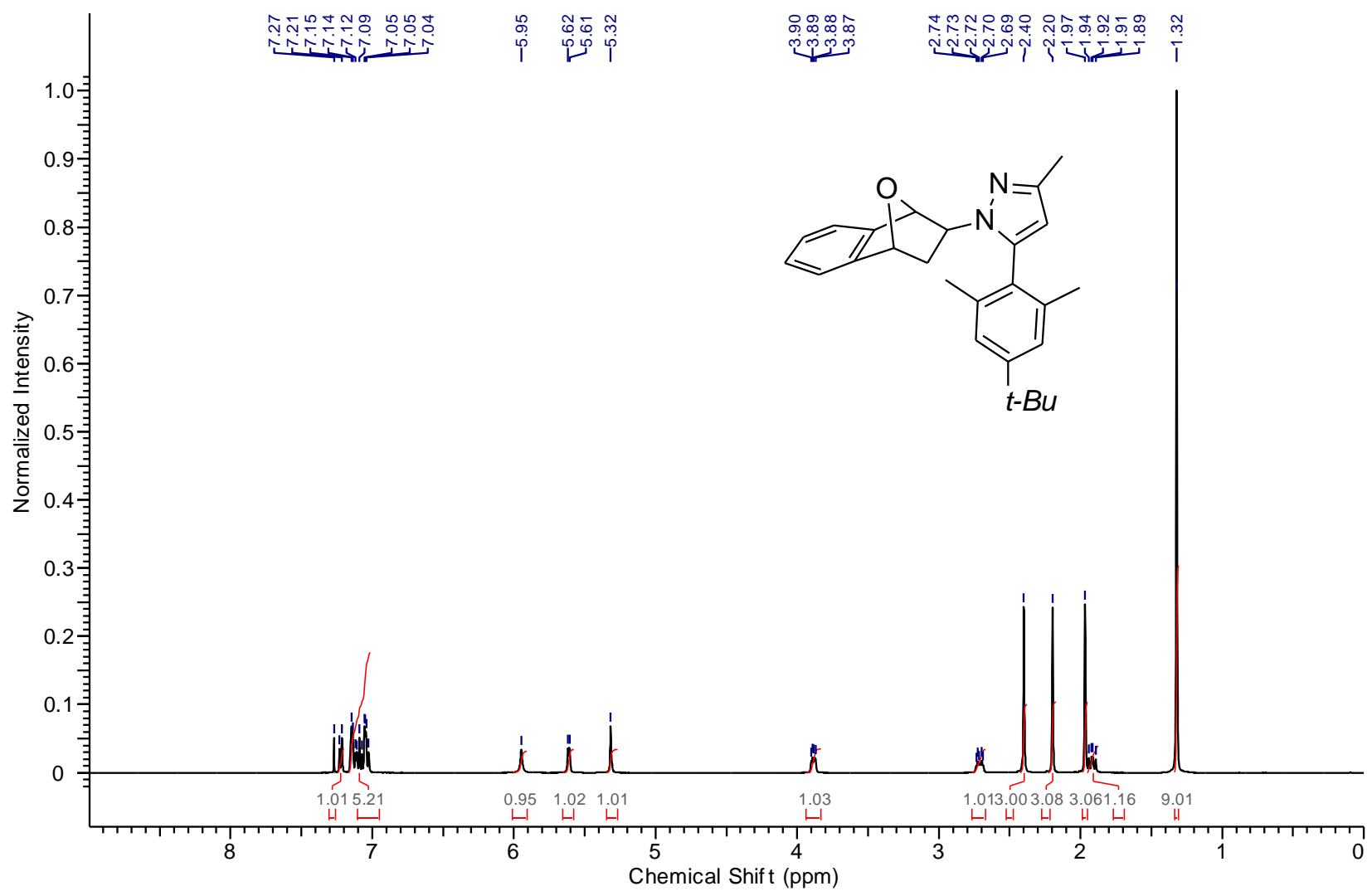

Figure S27. ${ }^{1} \mathrm{H}$ NMR spectrum of the compound $\mathbf{3 m}$ in $\mathrm{CDCl}_{3}, 400 \mathrm{MHz}$

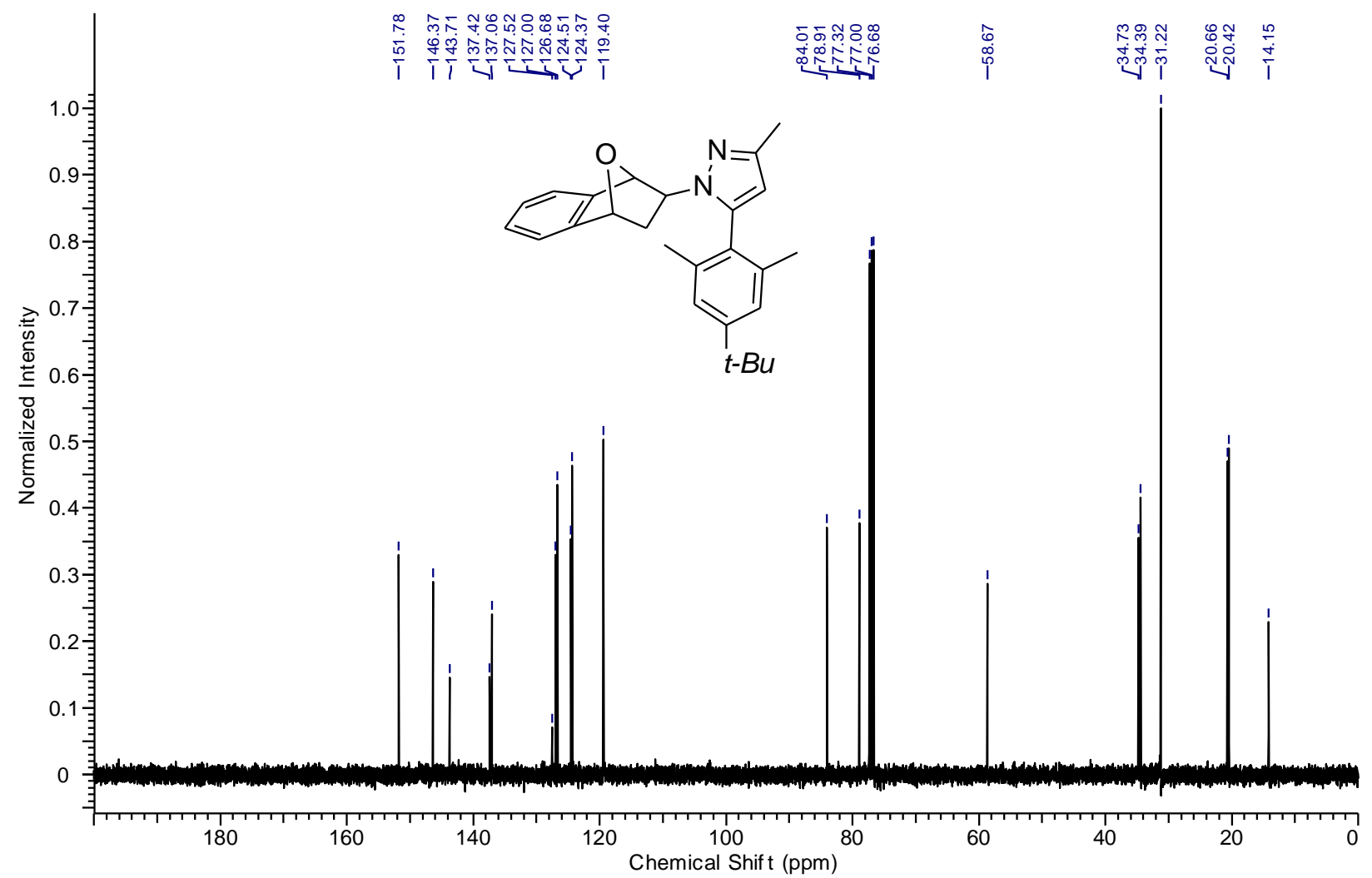

Figure S28. ${ }^{13} \mathrm{C}\left\{{ }^{1} \mathrm{H}\right\}$ NMR spectrum of the compound $\mathbf{3 m}$ in $\mathrm{CDCl}_{3}, 100 \mathrm{MHz}$ 


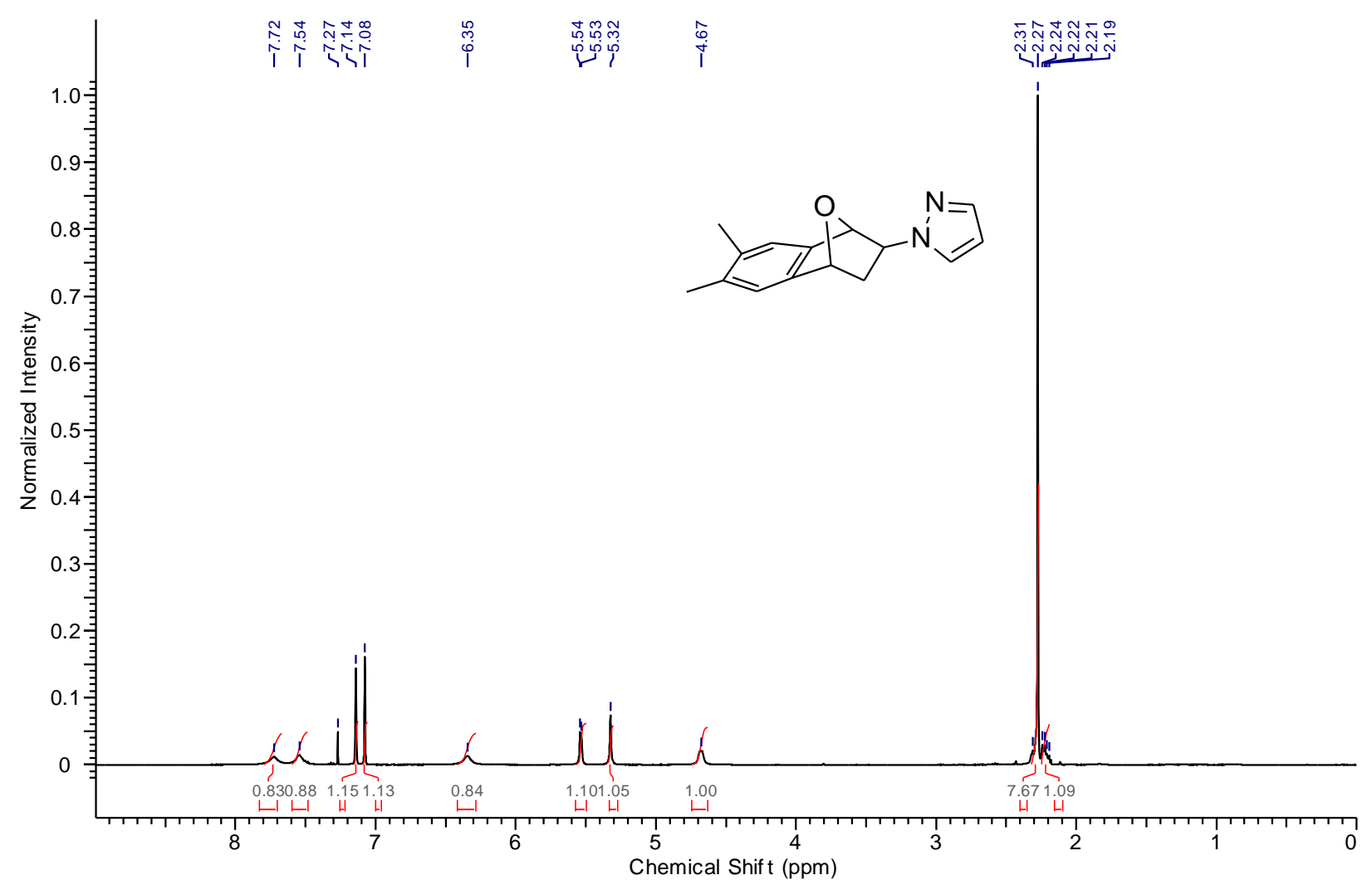

Figure S29. ${ }^{1} \mathrm{H}$ NMR spectrum of the compound $5 \mathbf{a a}$ in $\mathrm{CDCl}_{3}, 400 \mathrm{MHz}$

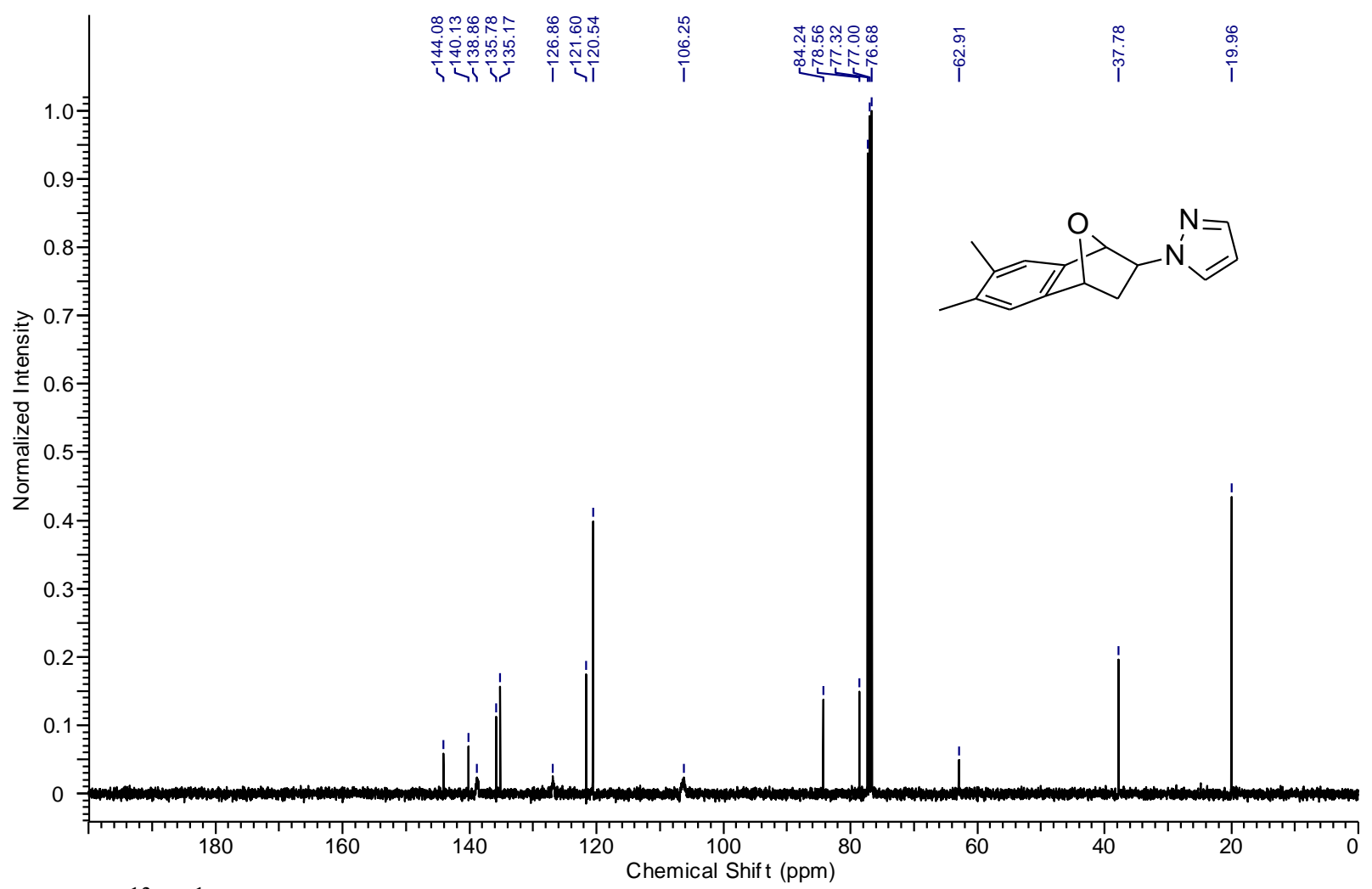

Figure S30. ${ }^{13} \mathrm{C}\left\{{ }^{1} \mathrm{H}\right\}$ NMR spectrum of the compound 5aa in $\mathrm{CDCl}_{3}, 100 \mathrm{MHz}$ 


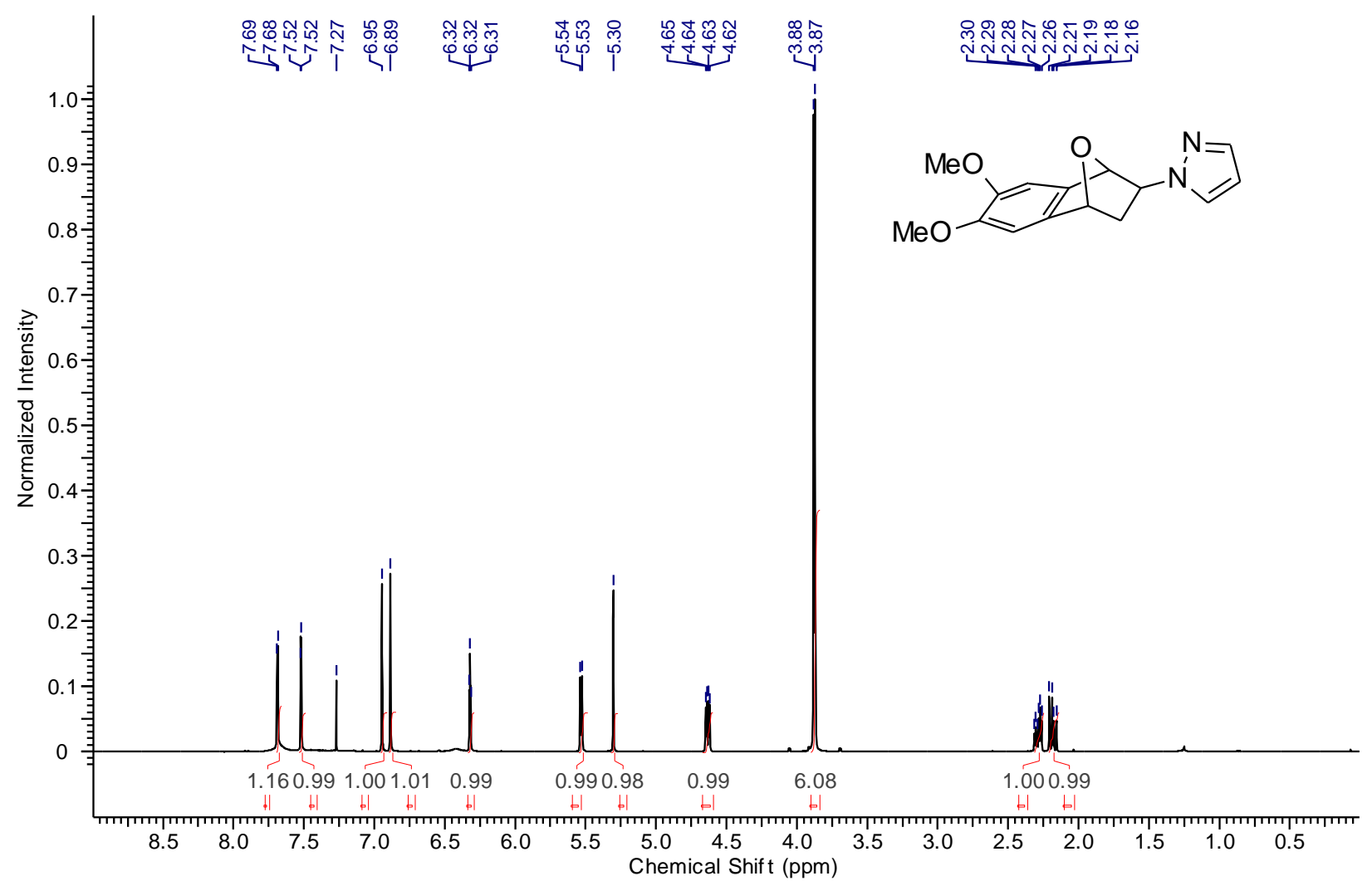

Figure S31. ${ }^{1} \mathrm{H}$ NMR spectrum of the compound $\mathbf{5 b a}$ in $\mathrm{CDCl}_{3}, 400 \mathrm{MHz}$

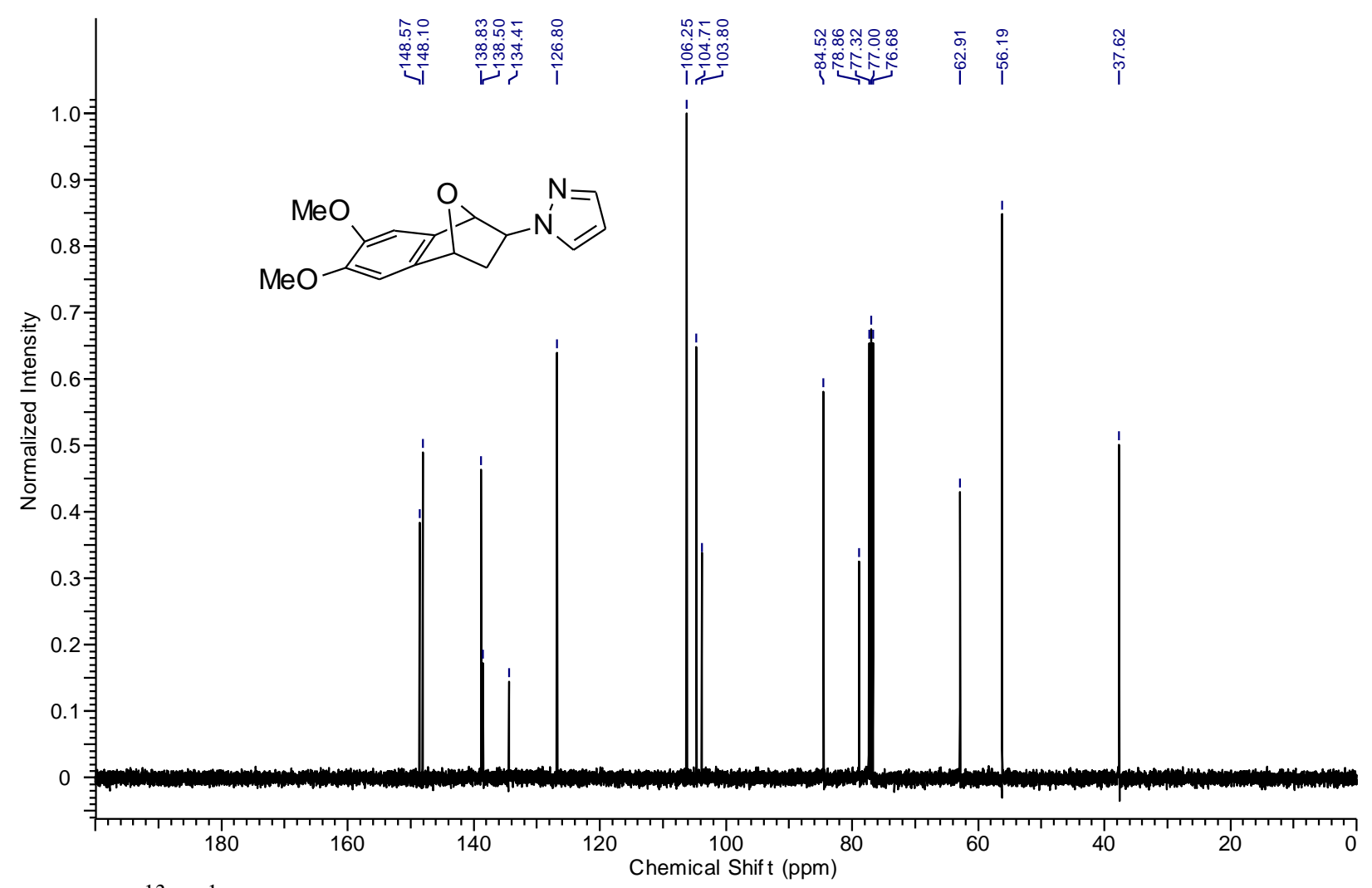

Figure S32. ${ }^{13} \mathrm{C}\left\{{ }^{1} \mathrm{H}\right\}$ NMR spectrum of the compound $\mathbf{5 b a}$ in $\mathrm{CDCl}_{3}, 100 \mathrm{MHz}$ 


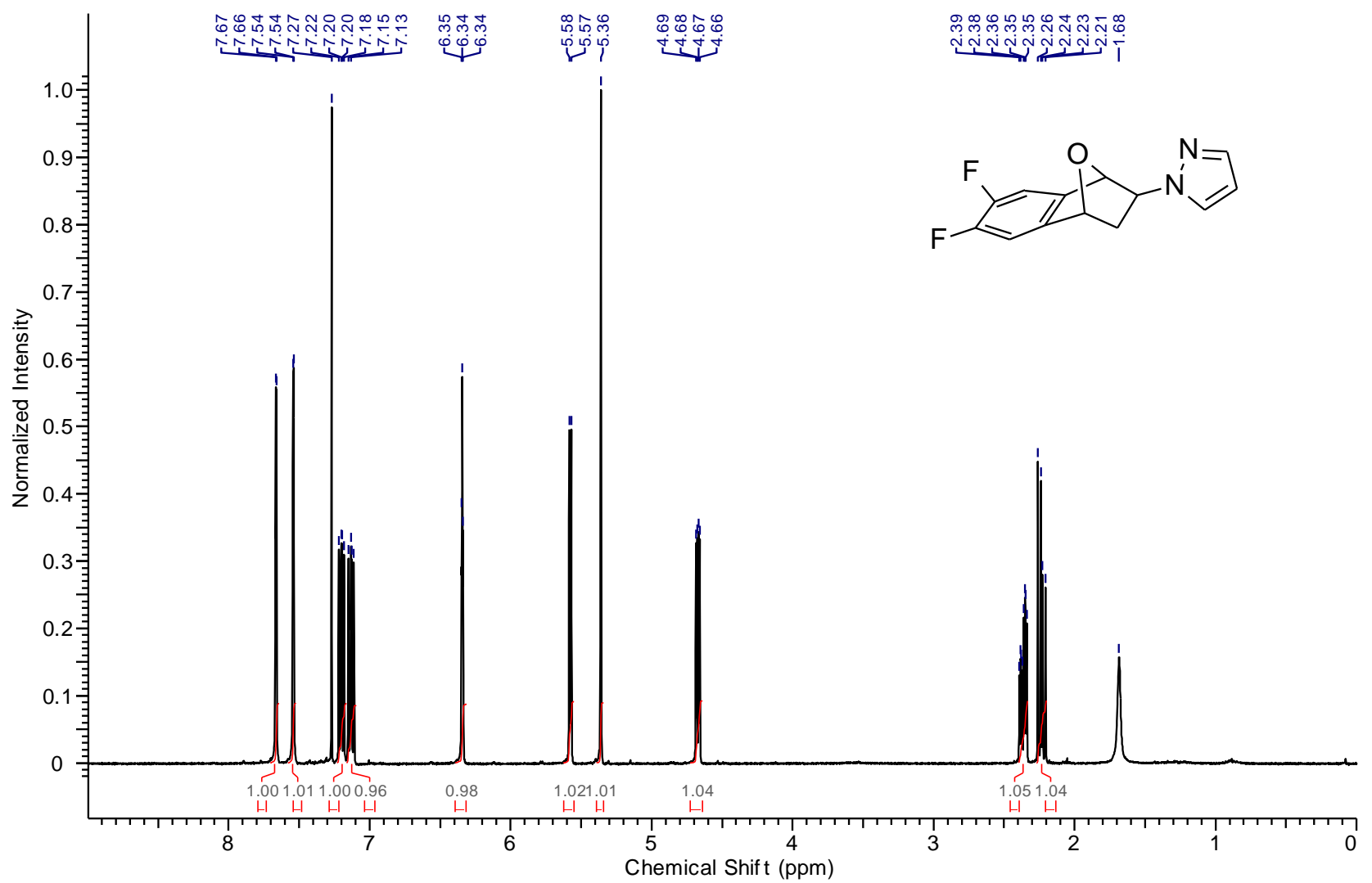

Figure S33. ${ }^{1} \mathrm{H}$ NMR spectrum of the compound $\mathbf{5} \mathbf{c a}$ in $\mathrm{CDCl}_{3}, 400 \mathrm{MHz}$

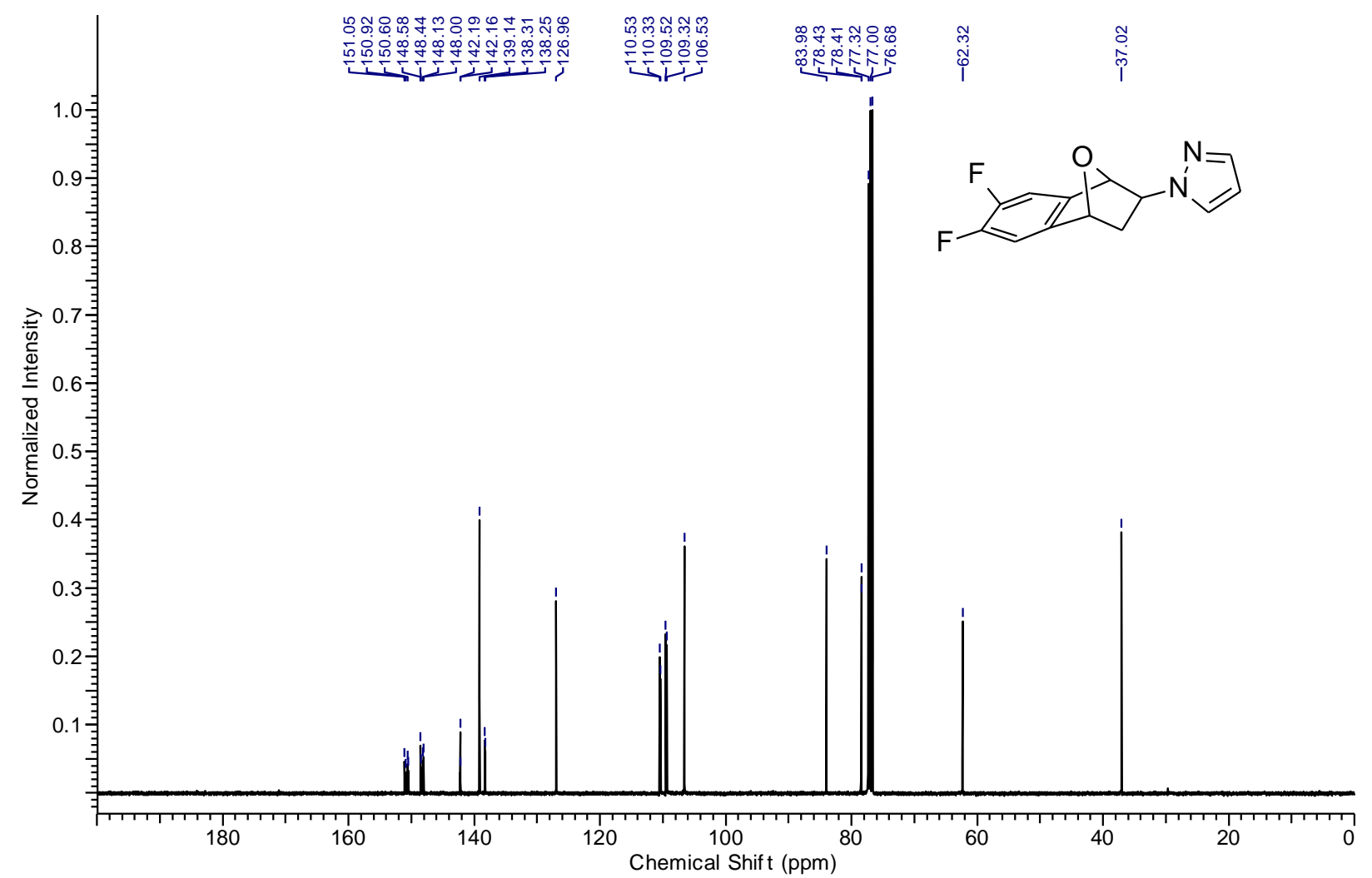

Figure S34. ${ }^{13} \mathrm{C}\left\{{ }^{1} \mathrm{H}\right\}$ NMR spectrum of the compound $\mathbf{5 c a}$ in $\mathrm{CDCl}_{3}, 100 \mathrm{MHz}$ 


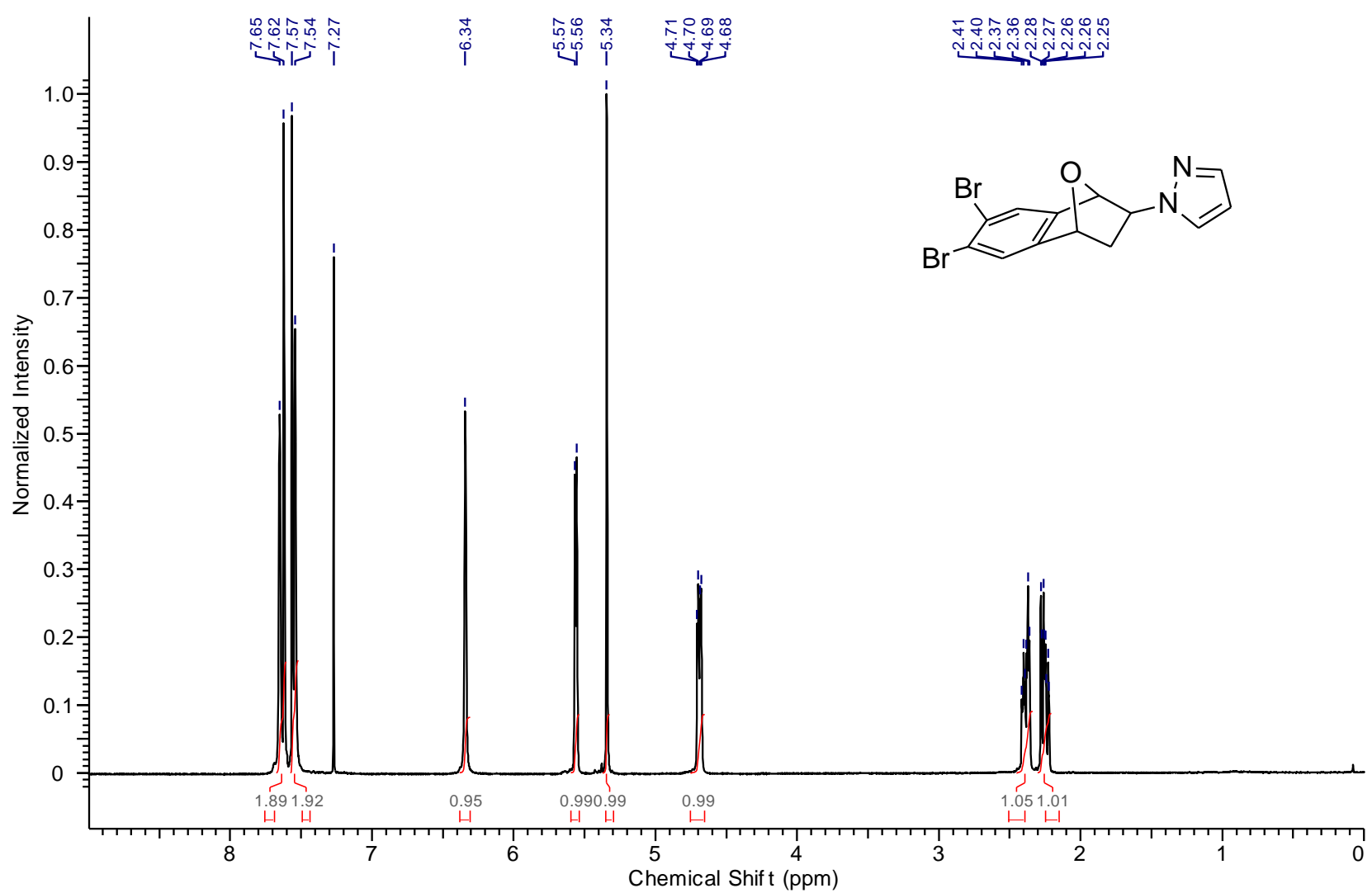

Figure S35. ${ }^{1} \mathrm{H}$ NMR spectrum of the compound $\mathbf{5 d a}$ in $\mathrm{CDCl}_{3}, 400 \mathrm{MHz}$

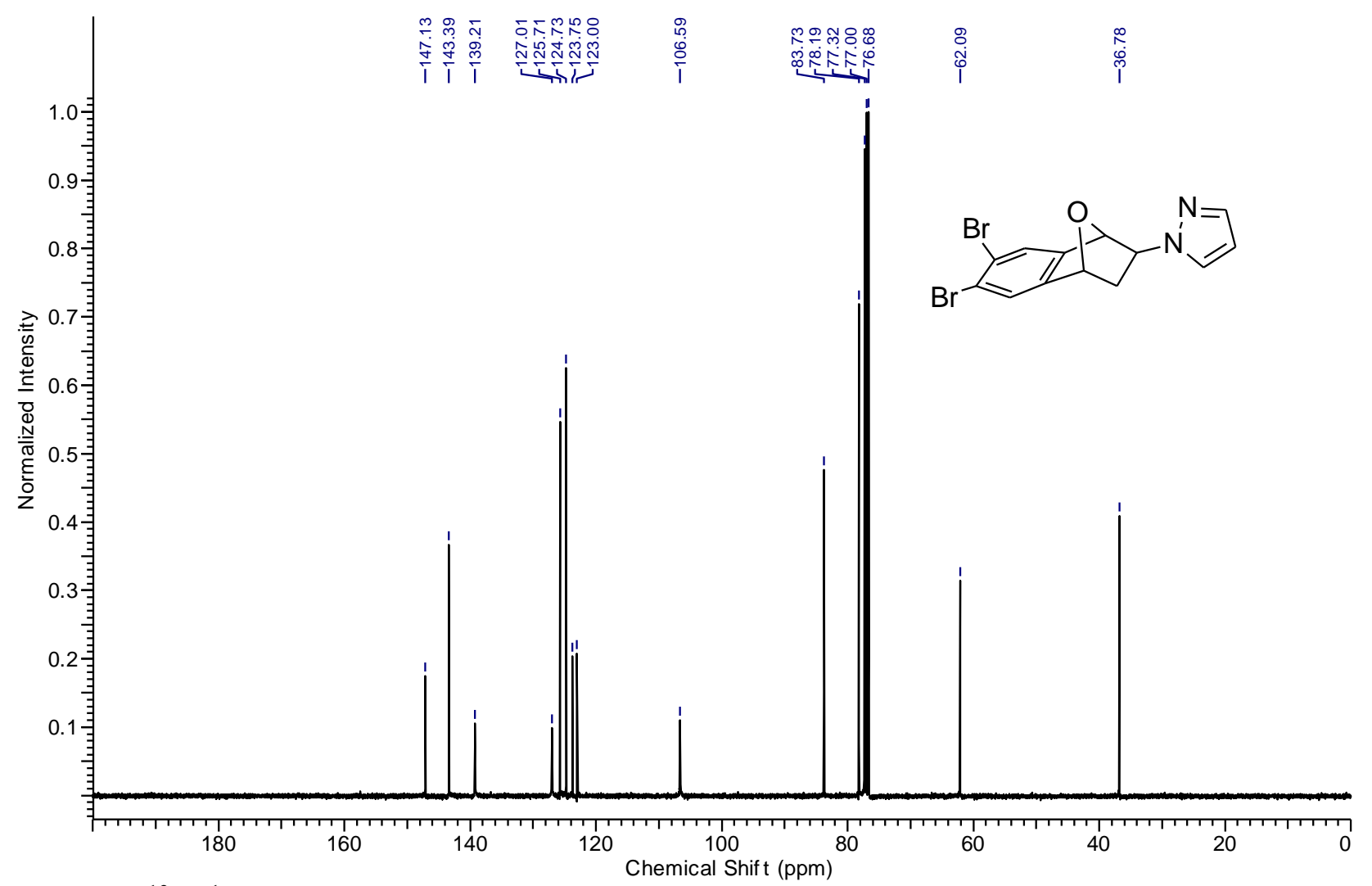

Figure S36. ${ }^{13} \mathrm{C}\left\{{ }^{1} \mathrm{H}\right\}$ NMR spectrum of the compound $\mathbf{5 d a}$ in $\mathrm{CDCl}_{3}, 100 \mathrm{MHz}$ 


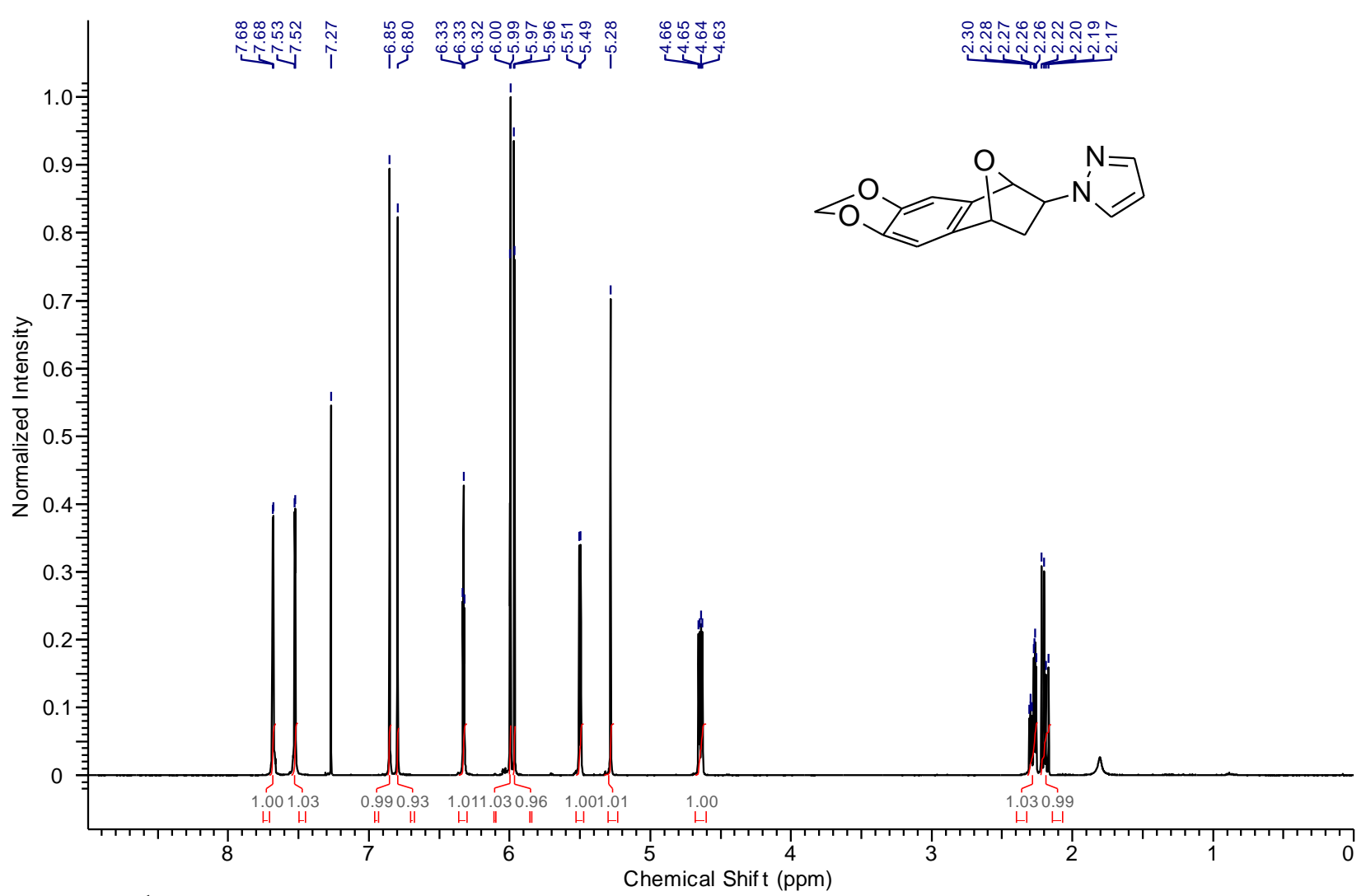

Figure S37. ${ }^{1} \mathrm{H}$ NMR spectrum of the compound $\mathbf{5 e a}$ in $\mathrm{CDCl}_{3}, 400 \mathrm{MHz}$

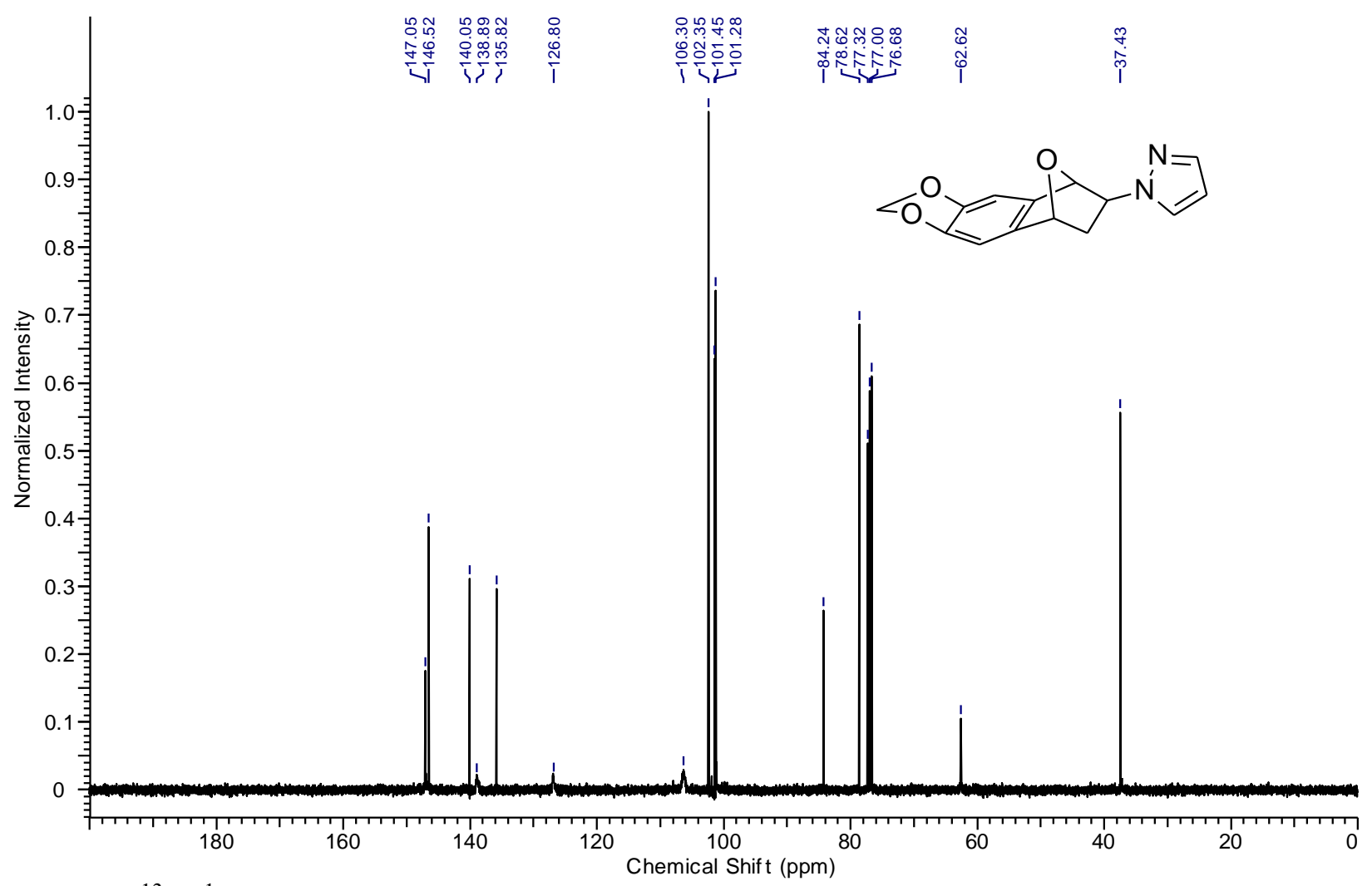

Figure S38. ${ }^{13} \mathrm{C}\left\{{ }^{1} \mathrm{H}\right\}$ NMR spectrum of the compound sea in $\mathrm{CDCl}_{3}, 100 \mathrm{MHz}$

S20 


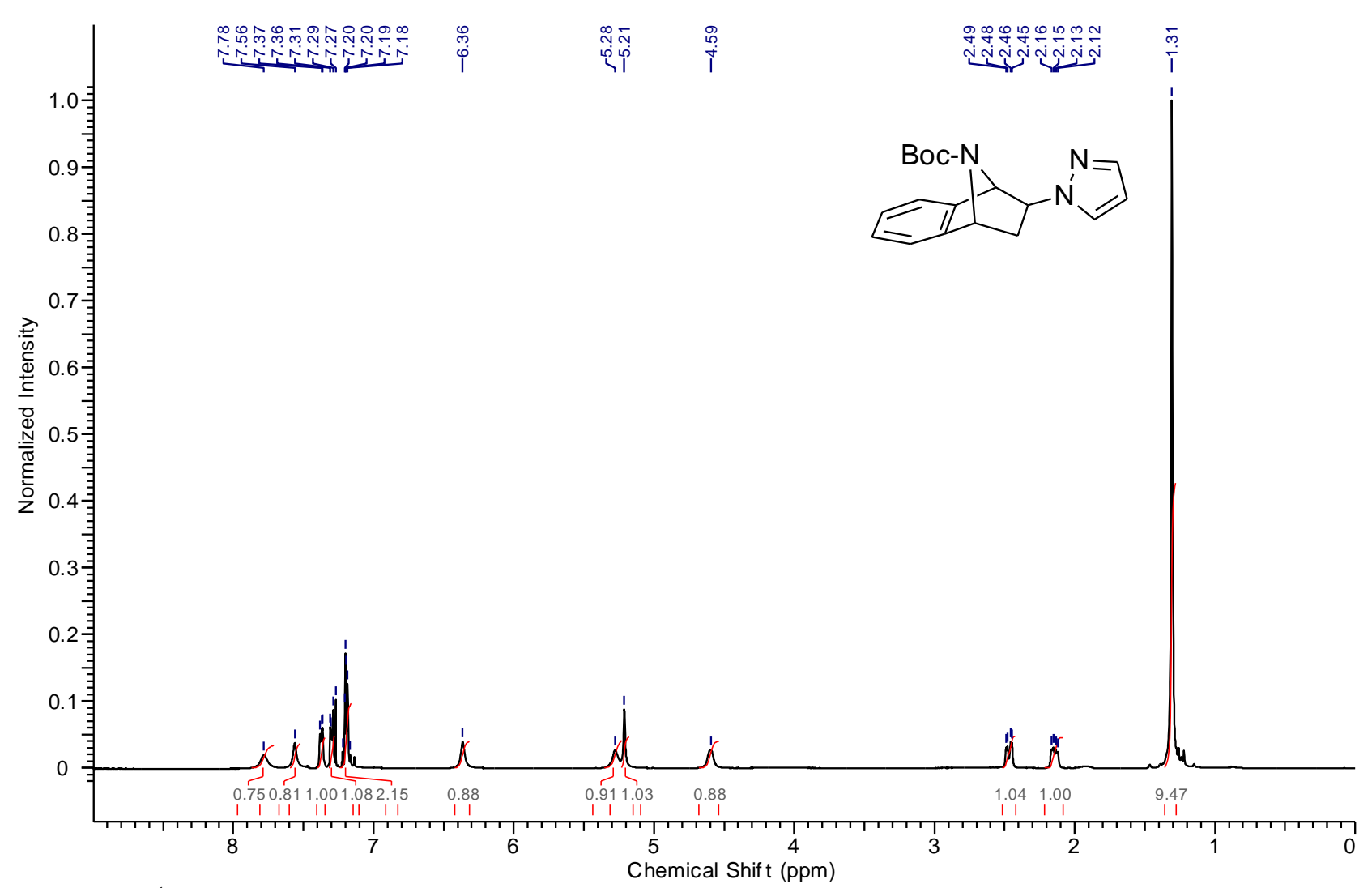

Figure S39. ${ }^{1} \mathrm{H}$ NMR spectrum of the compound $\mathbf{5 f a}$ in $\mathrm{CDCl}_{3}, 400 \mathrm{MHz}$

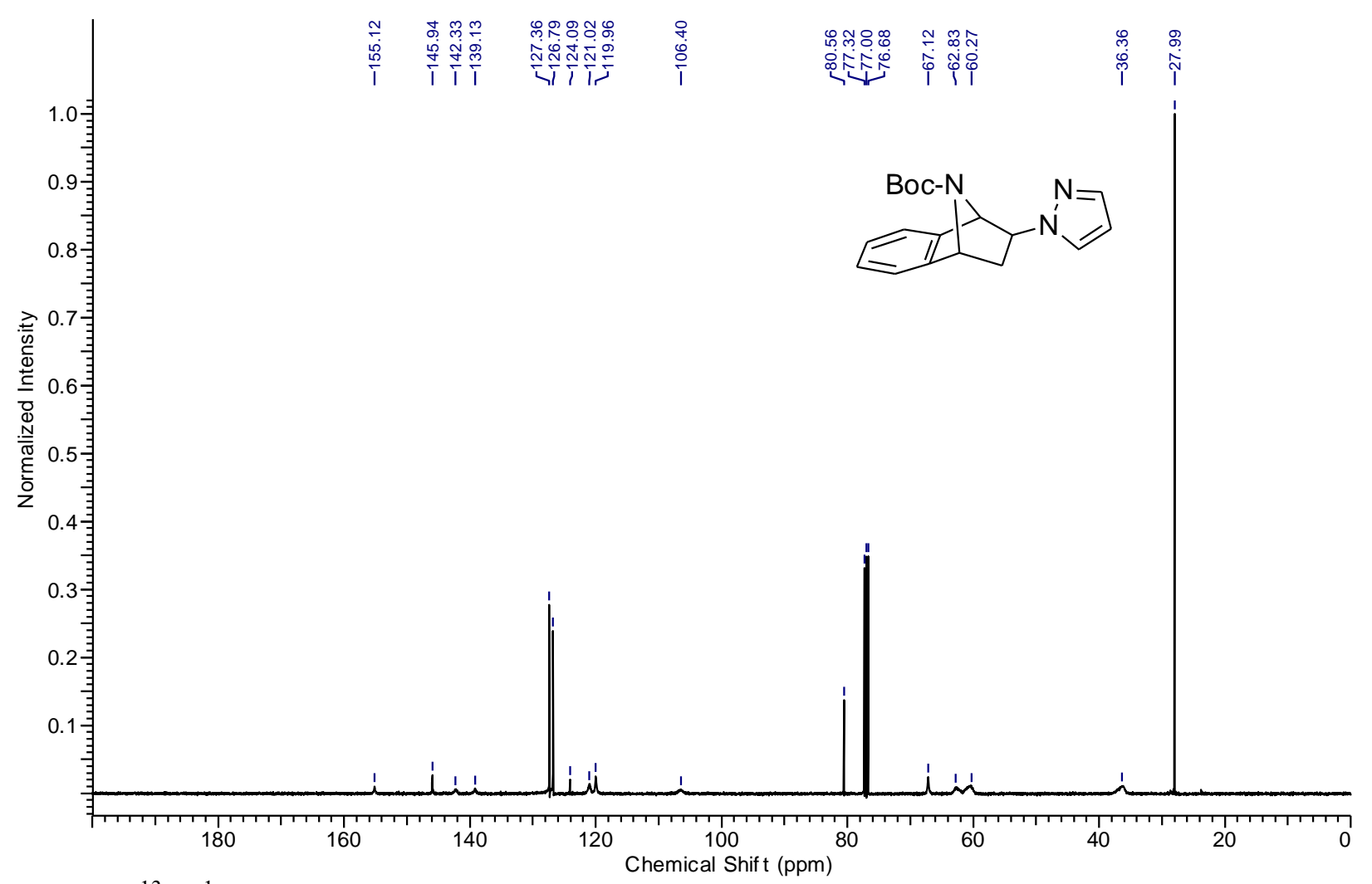

Figure S40. ${ }^{13} \mathrm{C}\left\{{ }^{1} \mathrm{H}\right\}$ NMR spectrum of the compound $\mathbf{5 f a}$ in $\mathrm{CDCl}_{3}, 100 \mathrm{MHz}$

S21 


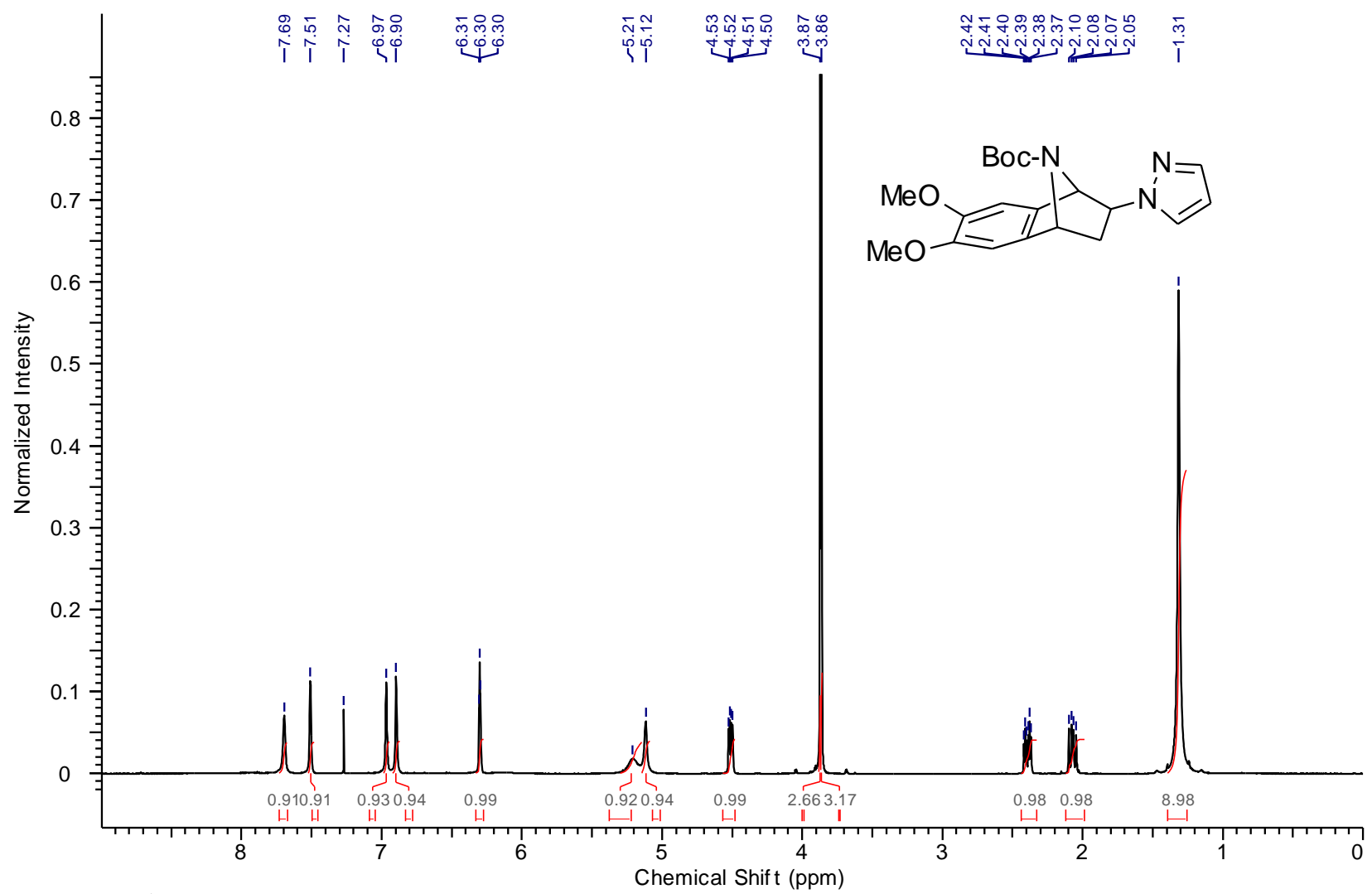

Figure S41. ${ }^{1} \mathrm{H}$ NMR spectrum of the compound $5 \mathbf{g a}$ in $\mathrm{CDCl}_{3}, 400 \mathrm{MHz}$

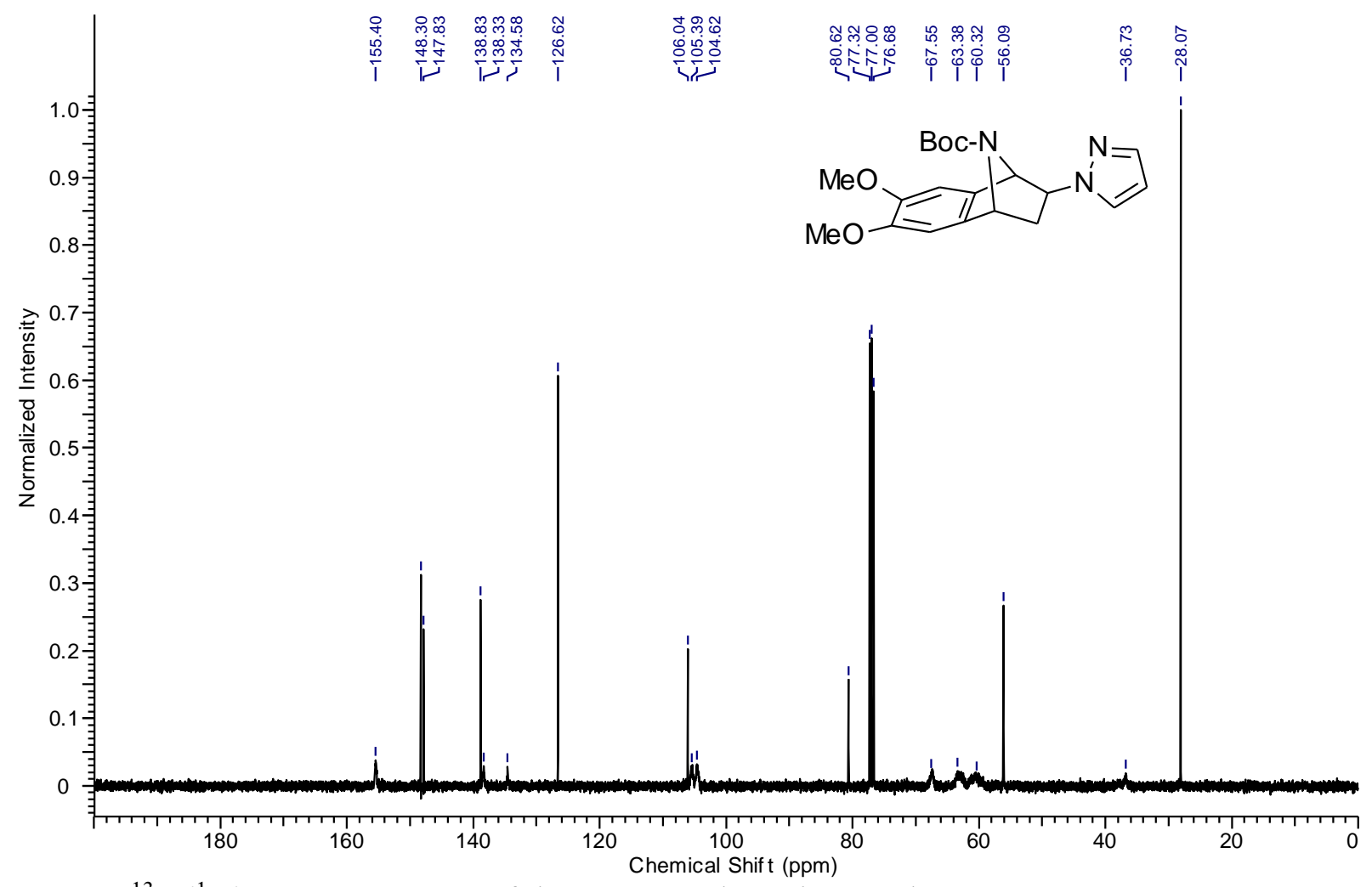

Figure S42. ${ }^{13} \mathrm{C}\left\{{ }^{1} \mathrm{H}\right\}$ NMR spectrum of the compound $\mathbf{5 g a}$ in $\mathrm{CDCl}_{3}, 100 \mathrm{MHz}$ 


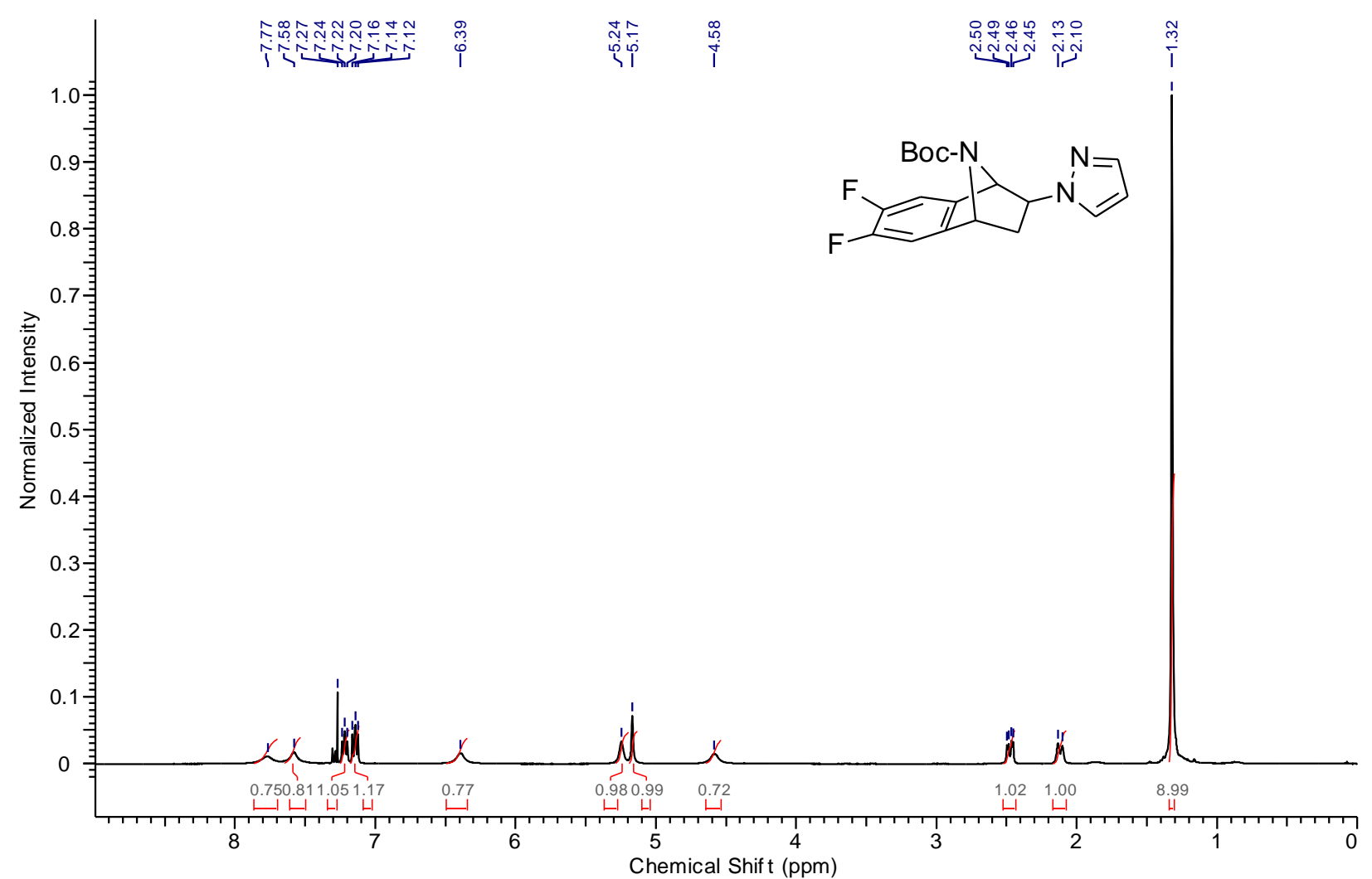

Figure S43. ${ }^{1} \mathrm{H}$ NMR spectrum of the compound 5 ha in $\mathrm{CDCl}_{3}, 400 \mathrm{MHz}$

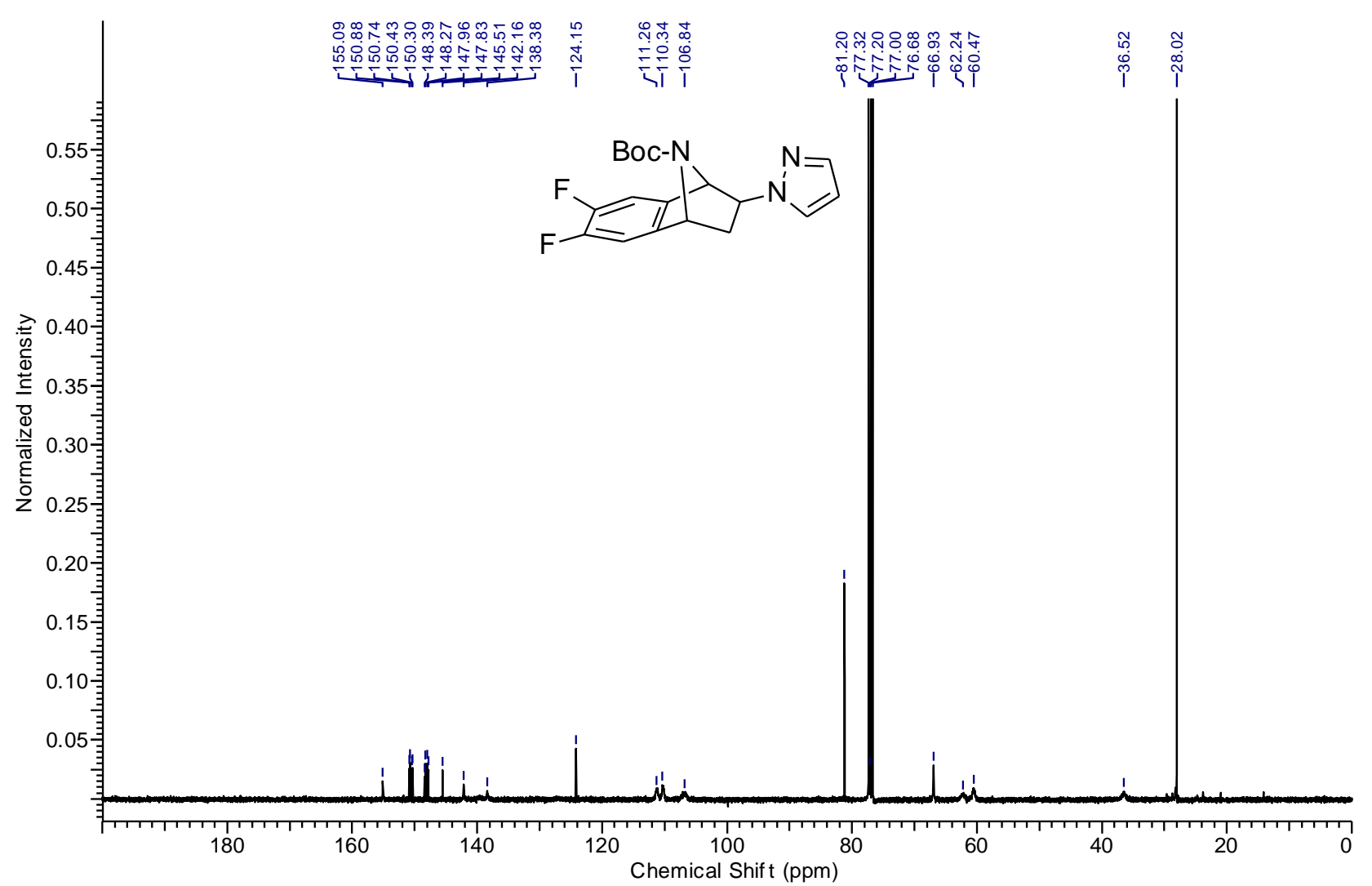

Figure S44. ${ }^{13} \mathrm{C}\left\{{ }^{1} \mathrm{H}\right\}$ NMR spectrum of the compound 5 ha in $\mathrm{CDCl}_{3}, 100 \mathrm{MHz}$ 


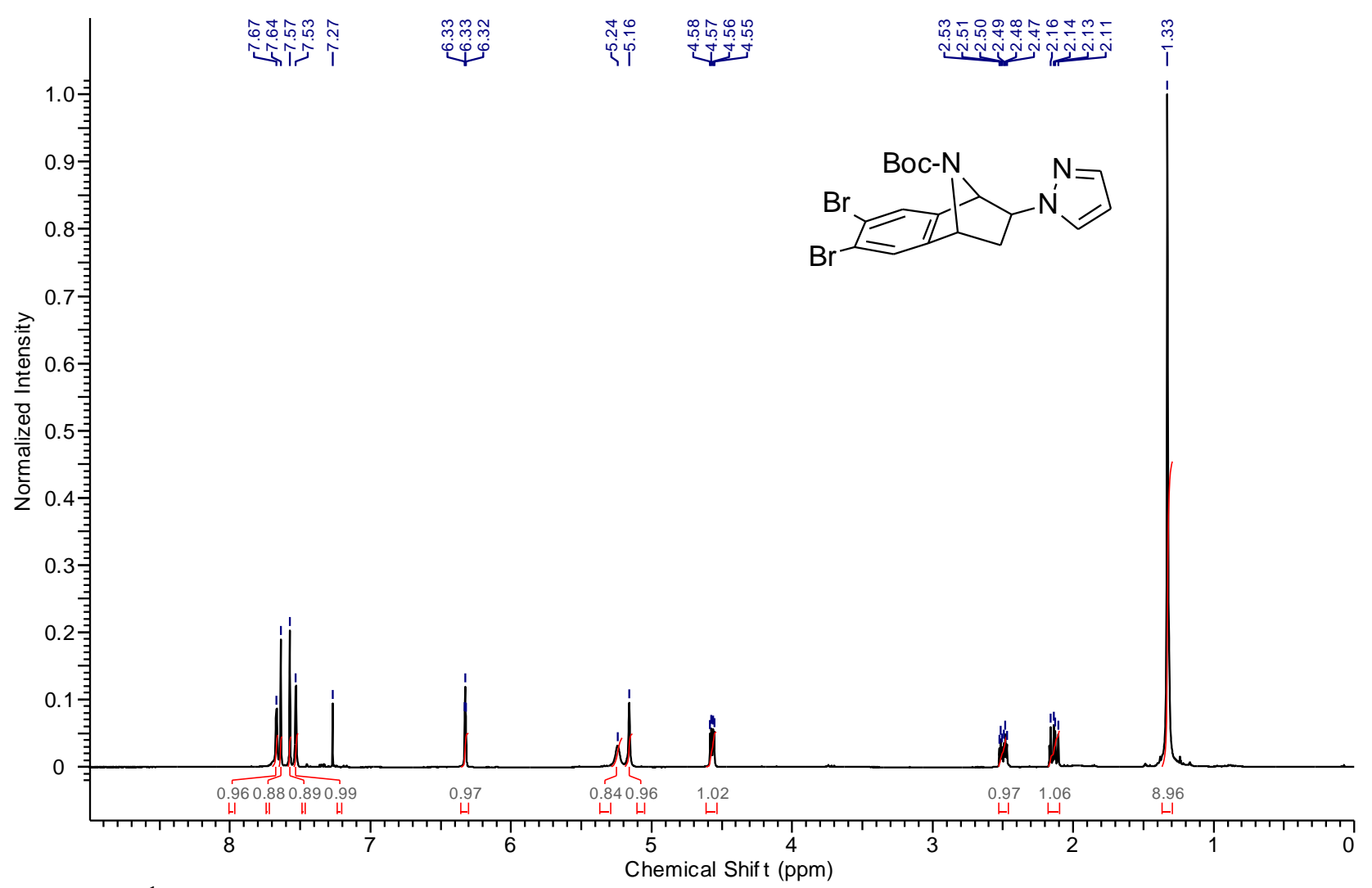

Figure S45. ${ }^{1} \mathrm{H}$ NMR spectrum of the compound 5 ia in $\mathrm{CDCl}_{3}, 400 \mathrm{MHz}$

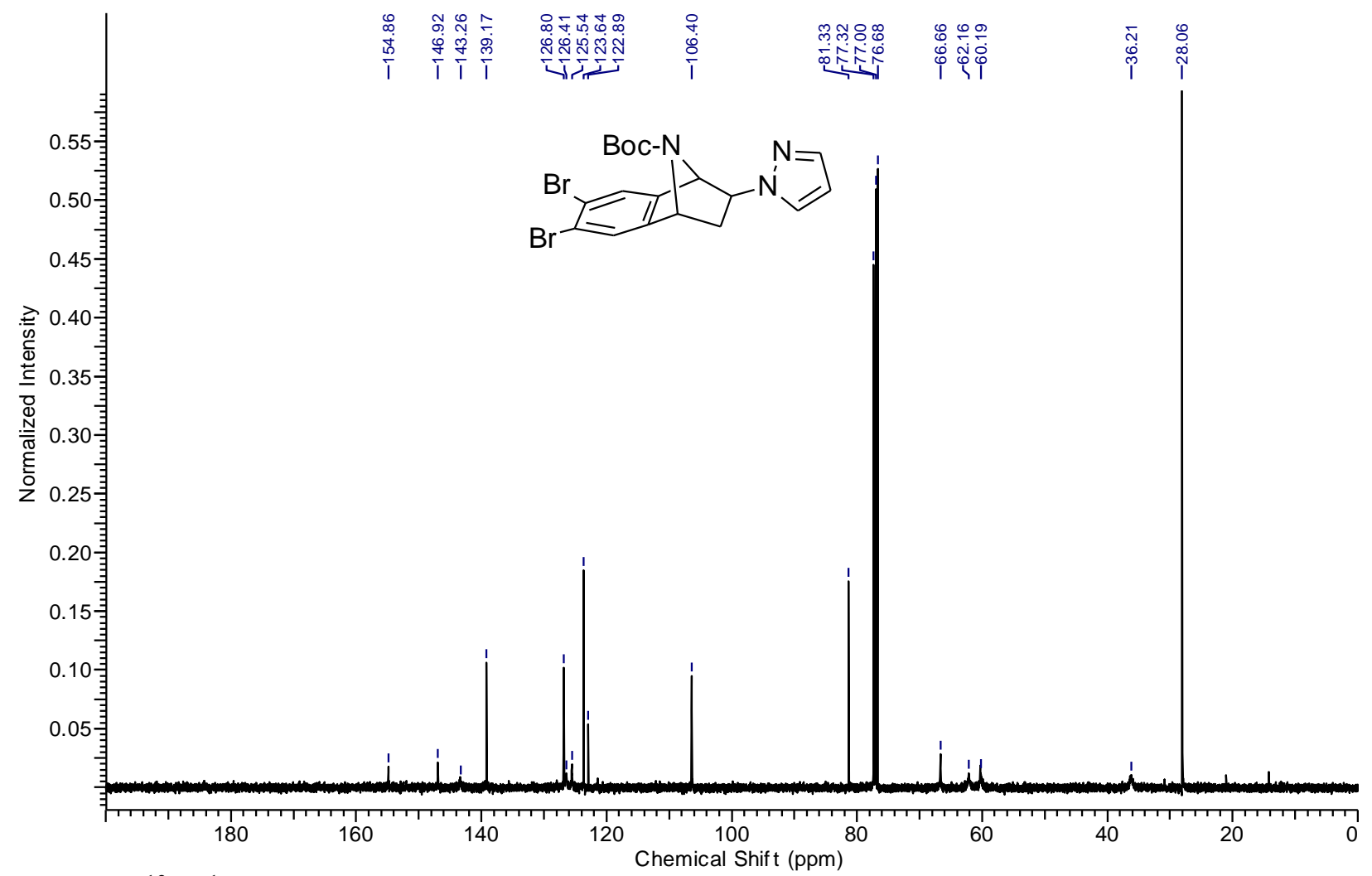

Figure S46. ${ }^{13} \mathrm{C}\left\{{ }^{1} \mathrm{H}\right\}$ NMR spectrum of the compound $\mathbf{5 i a}$ in $\mathrm{CDCl}_{3}, 100 \mathrm{MHz}$ 


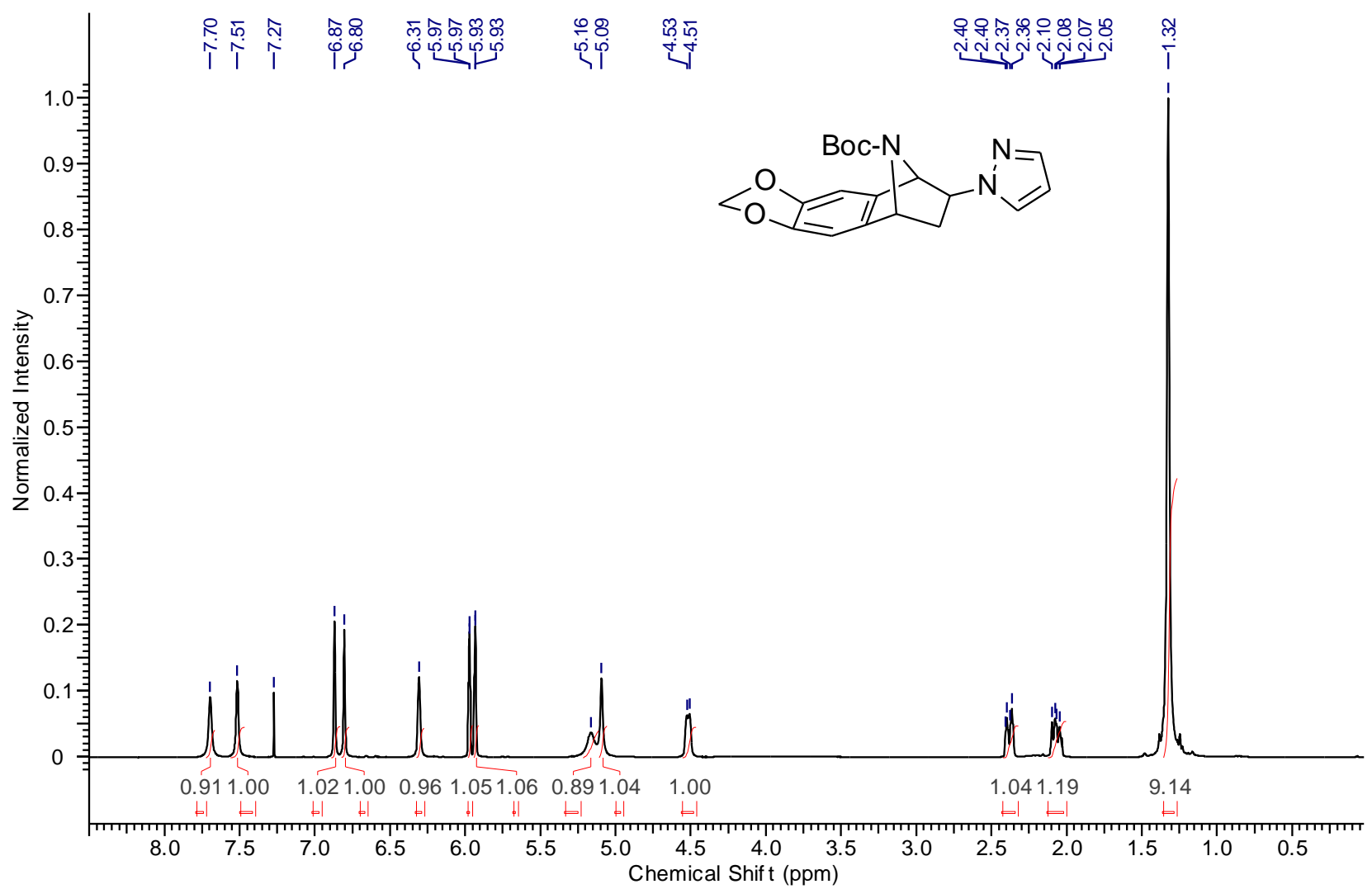

Figure S47. ${ }^{1} \mathrm{H}$ NMR spectrum of the compound $\mathbf{5 j a}$ in $\mathrm{CDCl}_{3}, 400 \mathrm{MHz}$

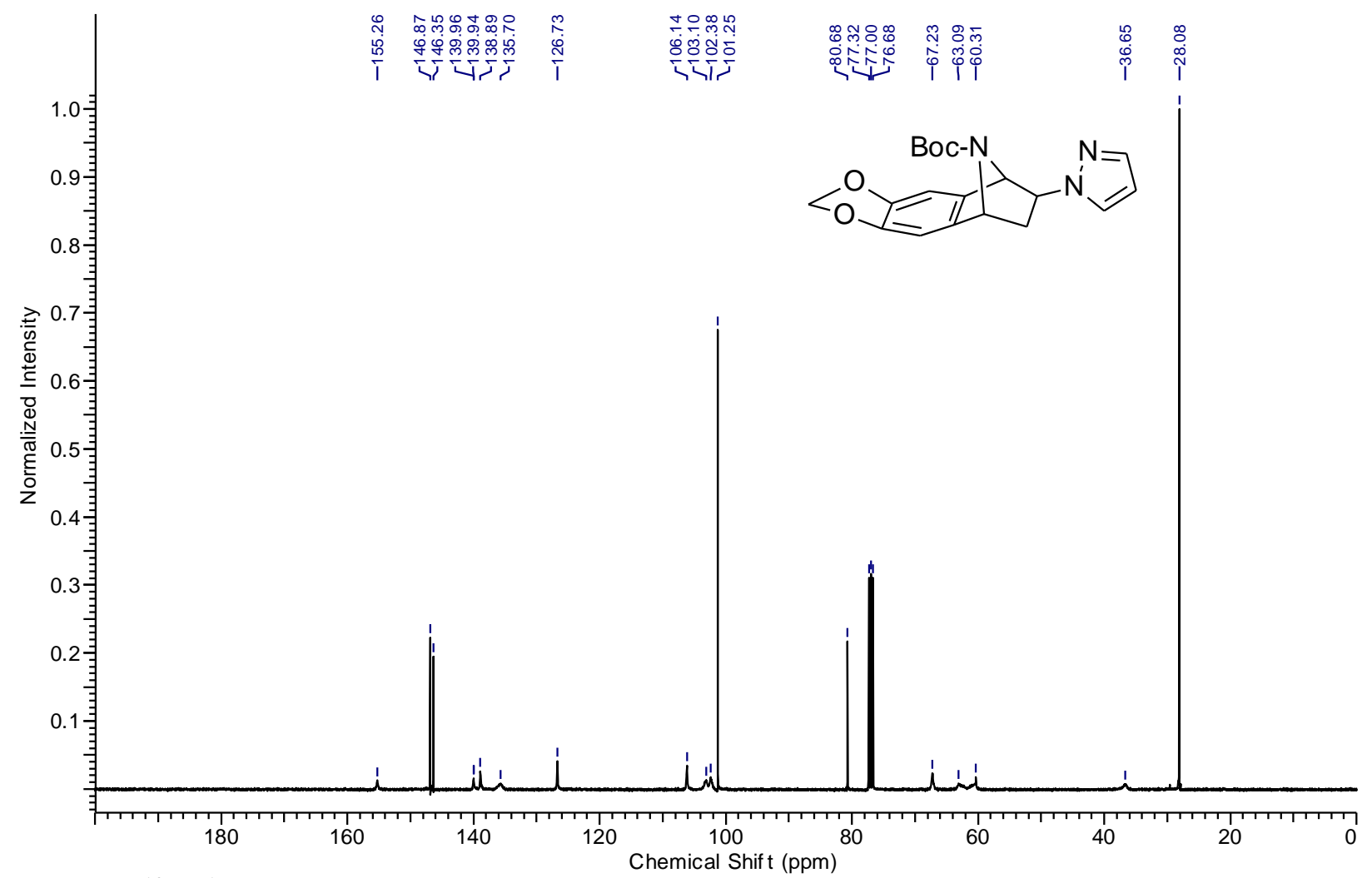

Figure $\mathbf{S 4 8} .{ }^{13} \mathrm{C}\left\{{ }^{1} \mathrm{H}\right\}$ NMR spectrum of the compound $\mathbf{5 j a}$ in $\mathrm{CDCl}_{3}, 100 \mathrm{MHz}$ 


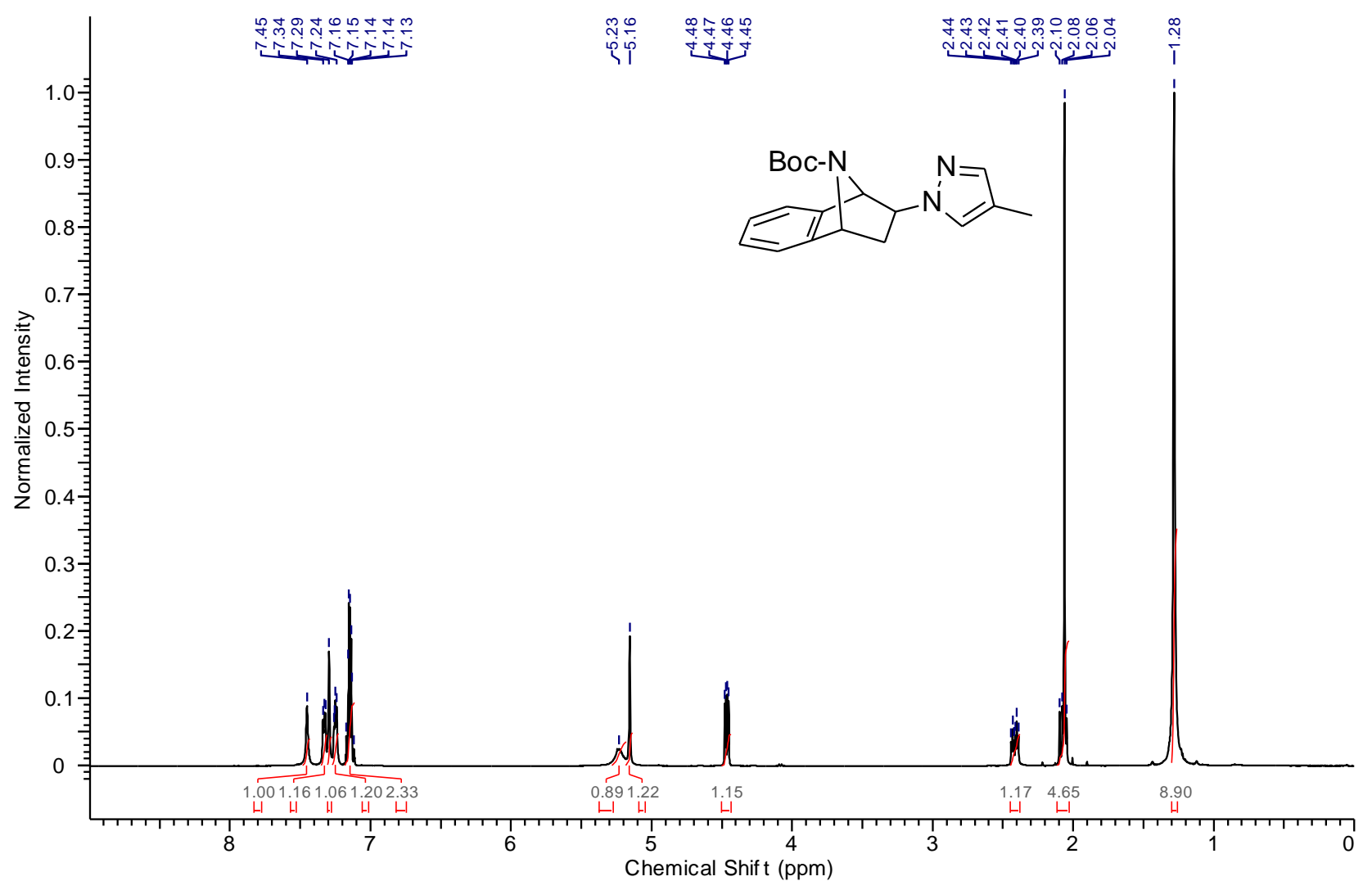

Figure S49. ${ }^{1} \mathrm{H}$ NMR spectrum of the compound $\mathbf{5 f b}$ in $\mathrm{CDCl}_{3}, 400 \mathrm{MHz}$

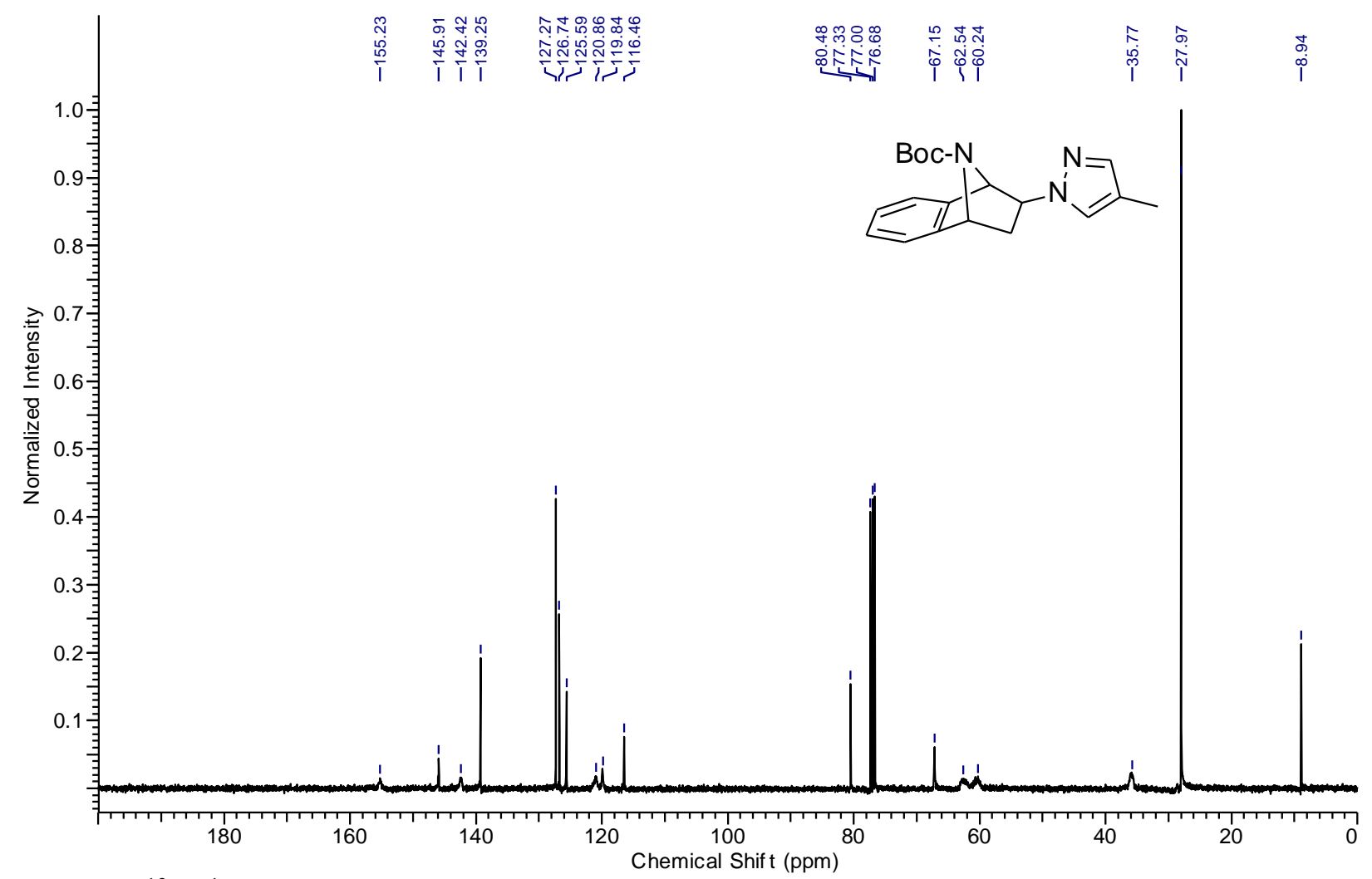

Figure S50. ${ }^{13} \mathrm{C}\left\{{ }^{1} \mathrm{H}\right\}$ NMR spectrum of the compound $\mathbf{5 f b}$ in $\mathrm{CDCl}_{3}, 100 \mathrm{MHz}$ 


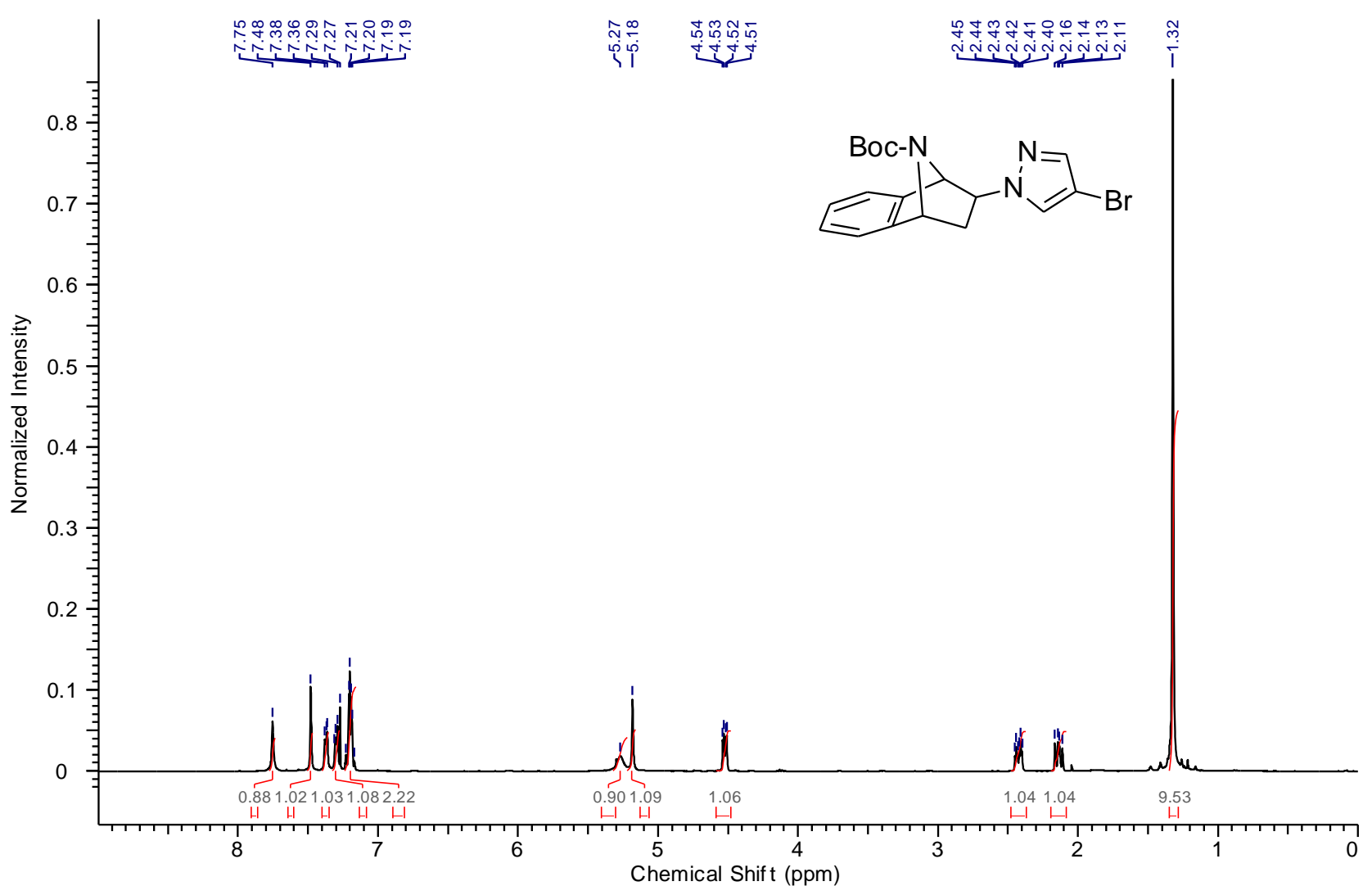

Figure S51. ${ }^{1} \mathrm{H}$ NMR spectrum of the compound $\mathbf{5 f d}$ in $\mathrm{CDCl}_{3}, 400 \mathrm{MHz}$

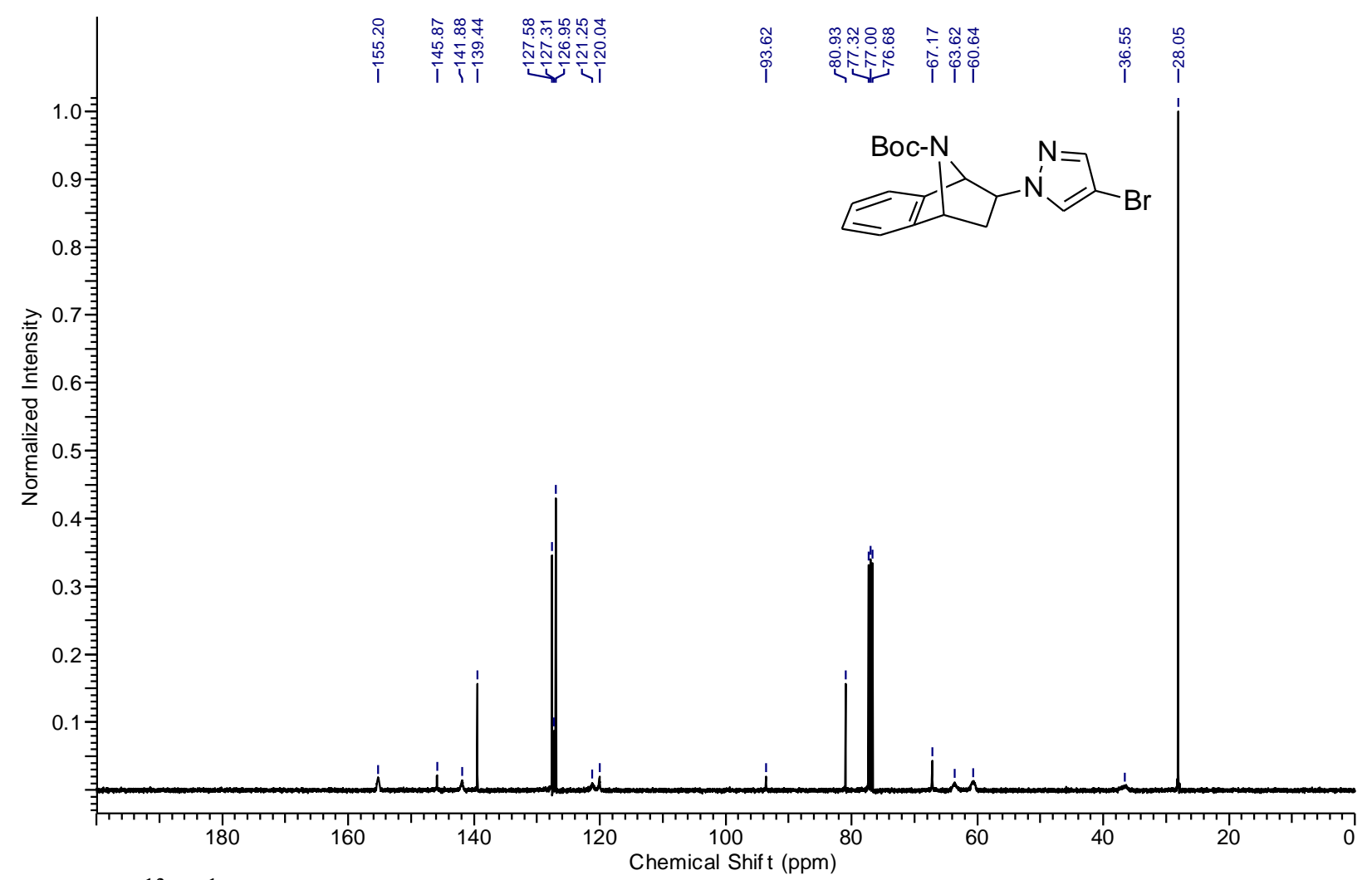

Figure S52. ${ }^{13} \mathrm{C}\left\{{ }^{1} \mathrm{H}\right\}$ NMR spectrum of the compound $\mathbf{5 f d}$ in $\mathrm{CDCl}_{3}, 100 \mathrm{MHz}$ 


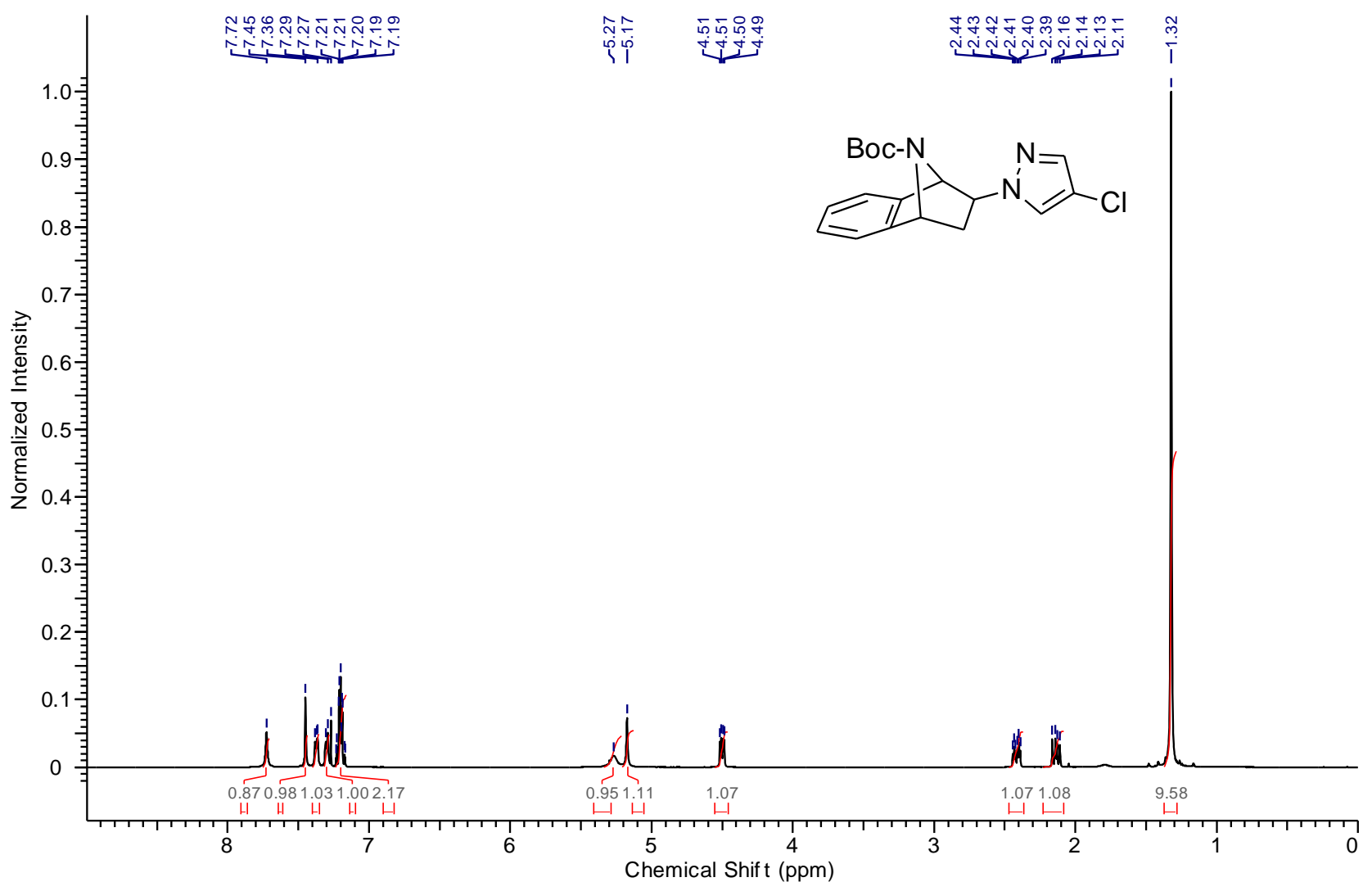

Figure S53. ${ }^{1} \mathrm{H}$ NMR spectrum of the compound $\mathbf{5 f e}$ in $\mathrm{CDCl}_{3}, 400 \mathrm{MHz}$

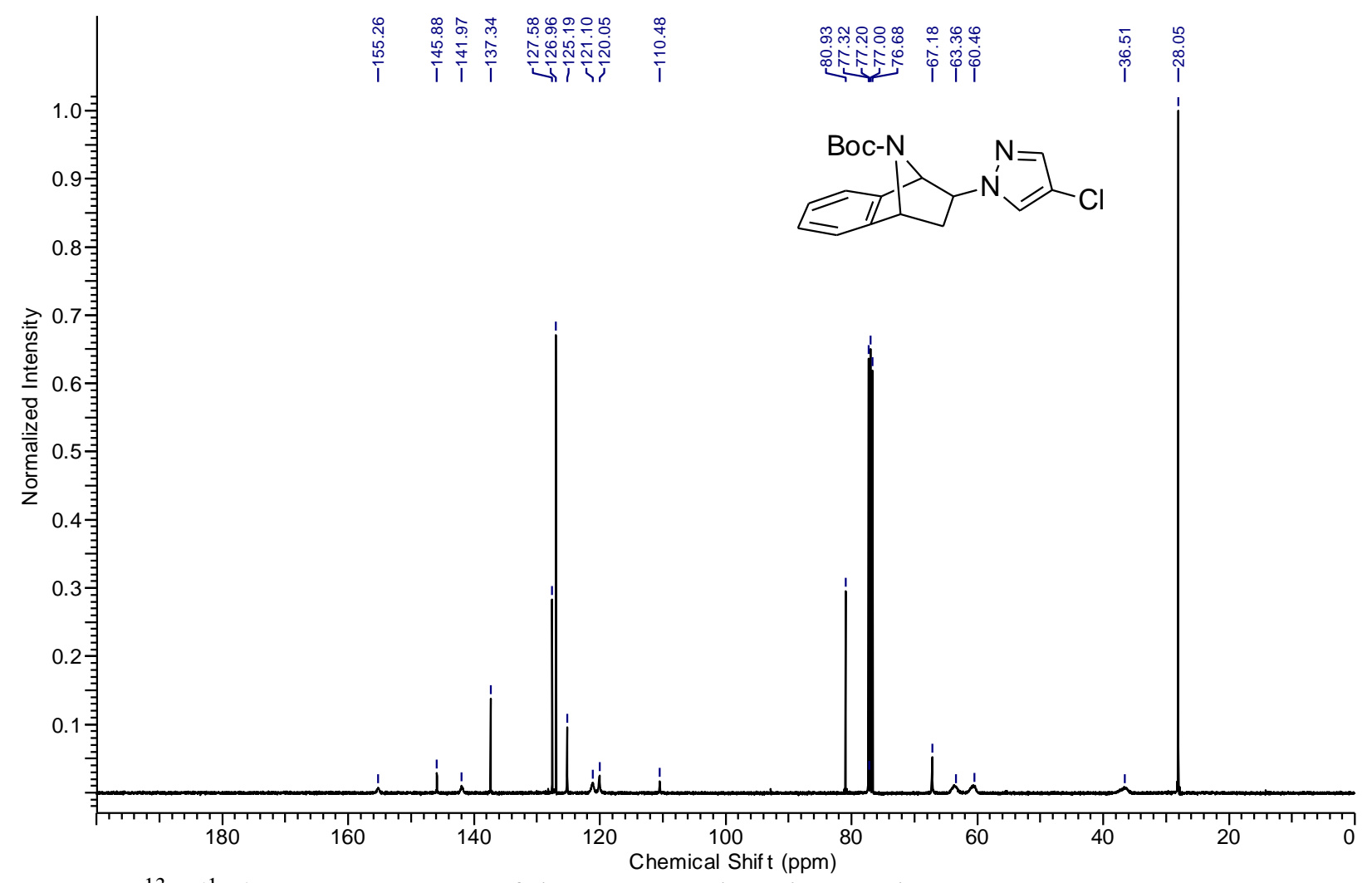

Figure S54. ${ }^{13} \mathrm{C}\left\{{ }^{1} \mathrm{H}\right\}$ NMR spectrum of the compound $\mathbf{5 f e}$ in $\mathrm{CDCl}_{3}, 100 \mathrm{MHz}$ 


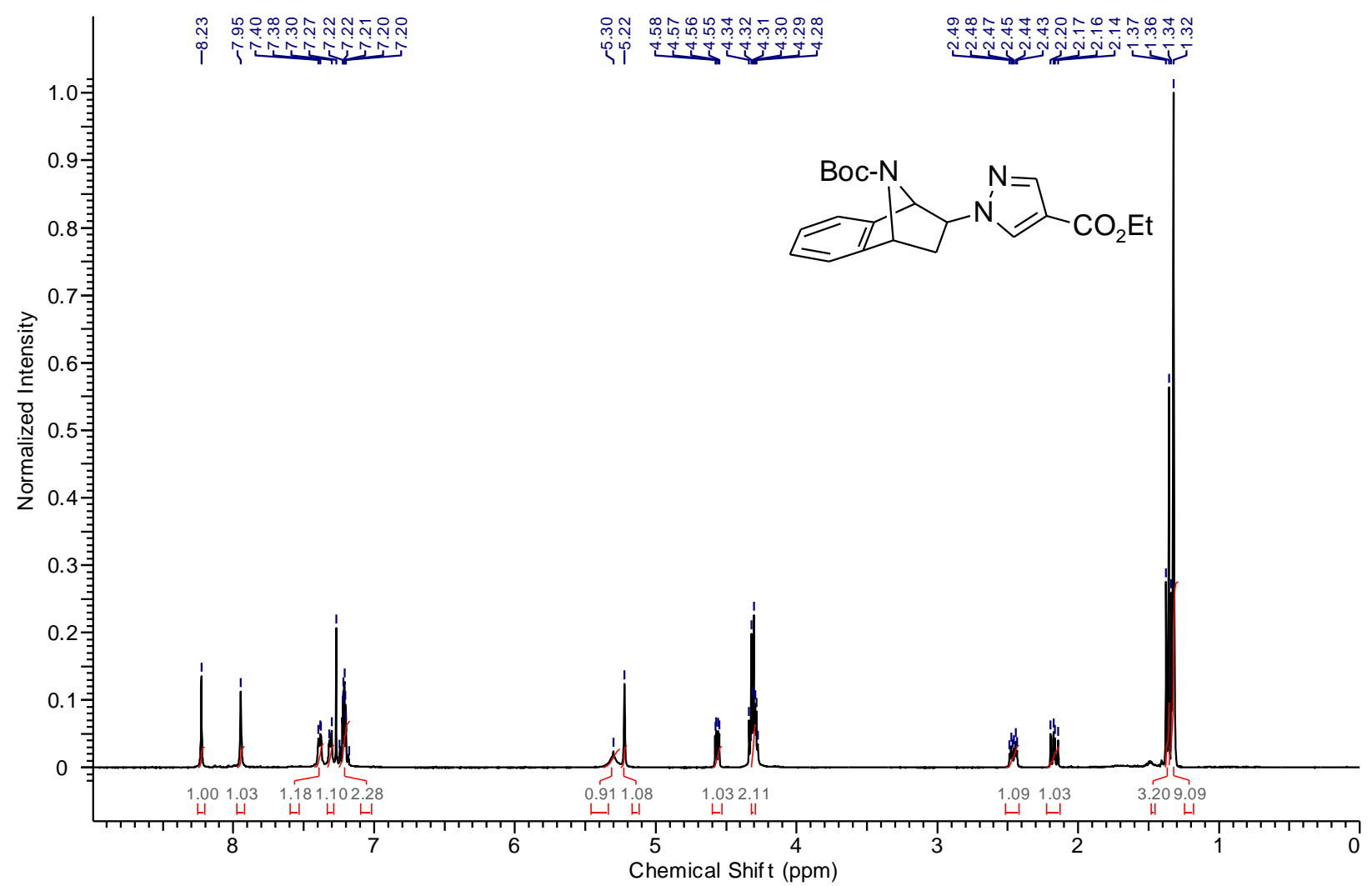

Figure S55. ${ }^{1} \mathrm{H}$ NMR spectrum of the compound $\mathbf{5 f f}$ in $\mathrm{CDCl}_{3}, 400 \mathrm{MHz}$

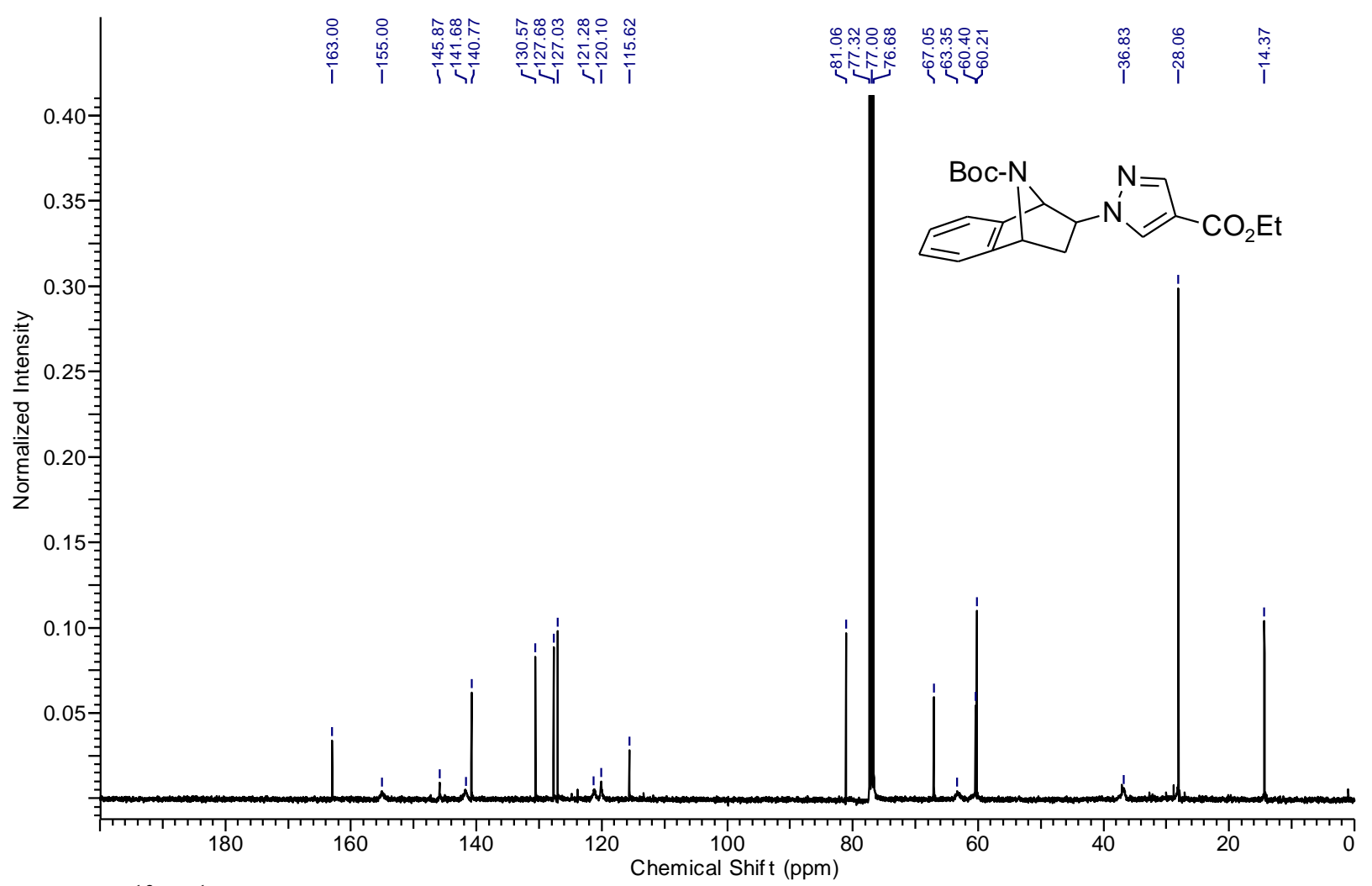

Figure S56. ${ }^{13} \mathrm{C}\left\{{ }^{1} \mathrm{H}\right\}$ NMR spectrum of the compound $\mathbf{5 f f}$ in $\mathrm{CDCl}_{3}, 100 \mathrm{MHz}$ 


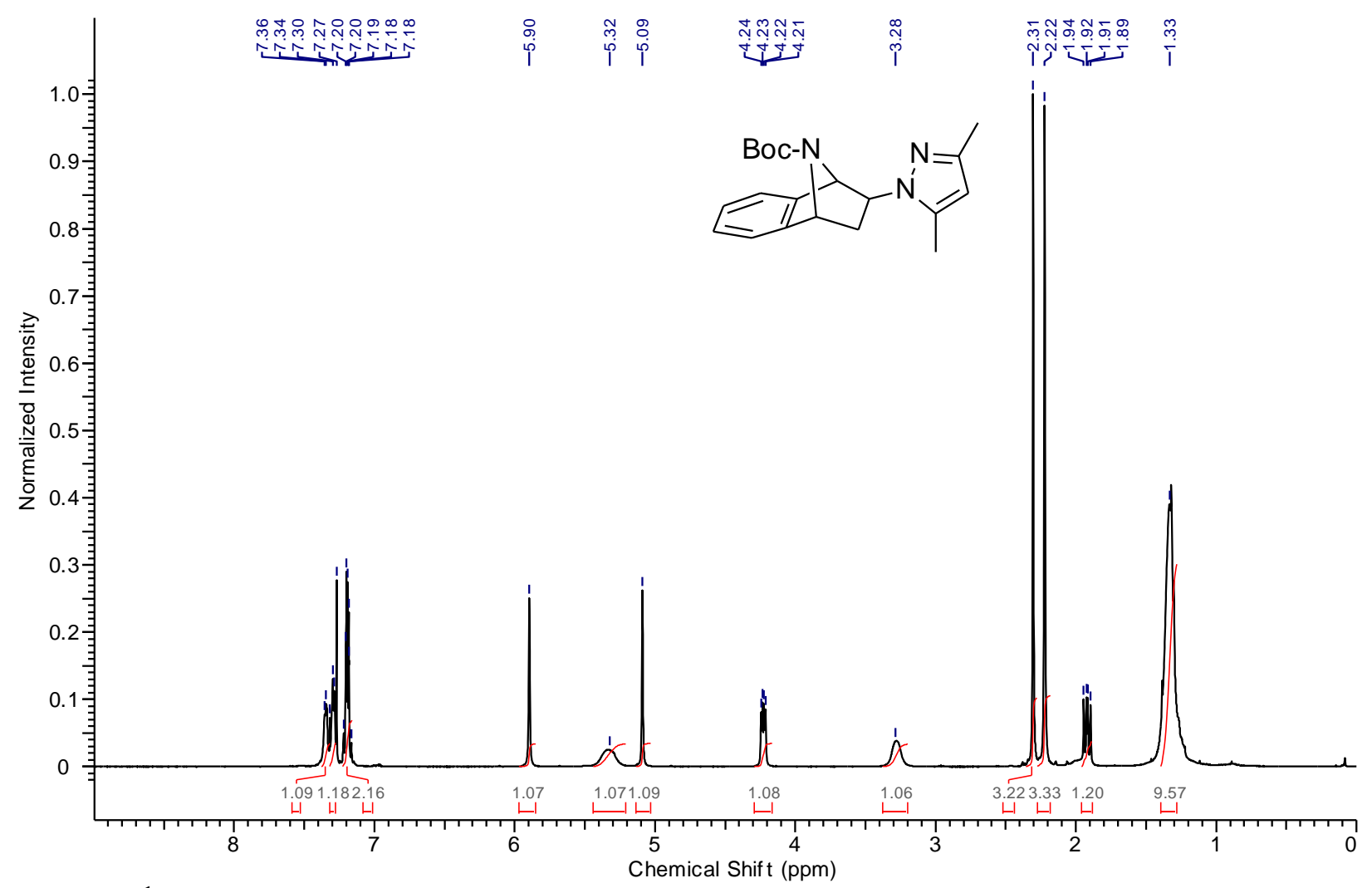

Figure S57. ${ }^{1} \mathrm{H}$ NMR spectrum of the compound $\mathbf{5 f g}$ in $\mathrm{CDCl}_{3}, 400 \mathrm{MHz}$

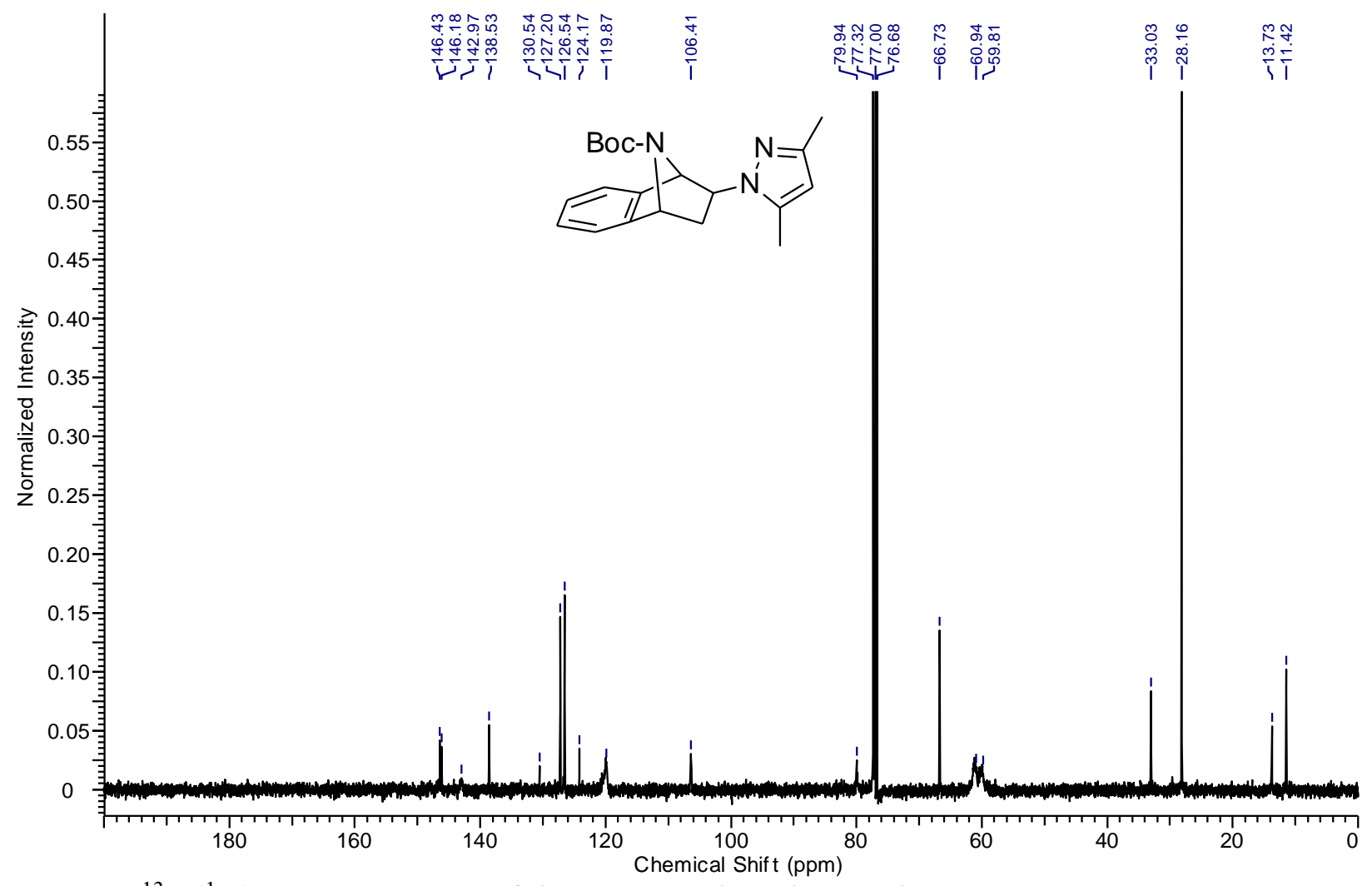

Figure S58. ${ }^{13} \mathrm{C}\left\{{ }^{1} \mathrm{H}\right\}$ NMR spectrum of the compound $\mathbf{5 f g}$ in $\mathrm{CDCl}_{3}, 100 \mathrm{MHz}$

S30 


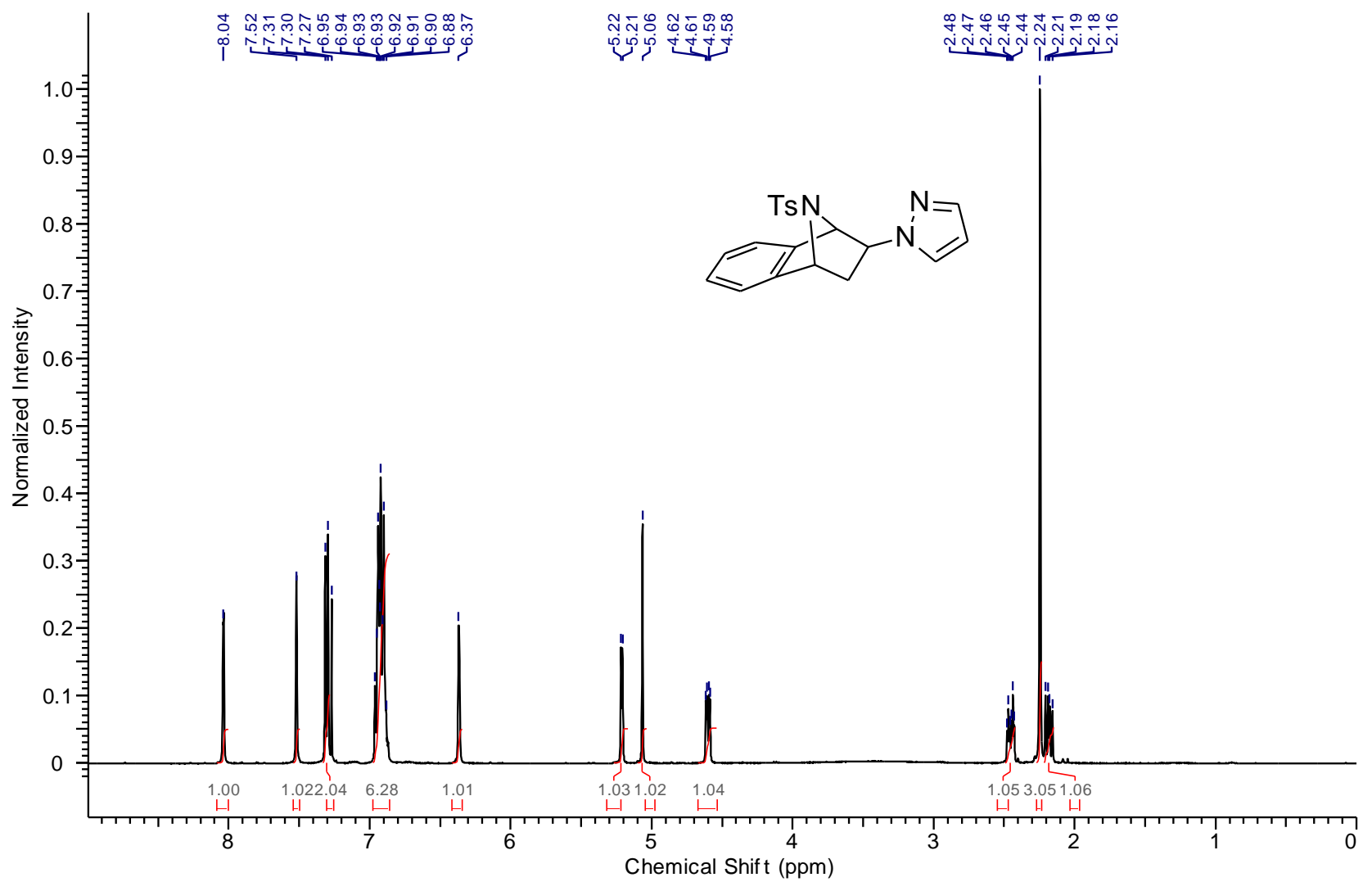

Figure S59. ${ }^{1} \mathrm{H}$ NMR spectrum of the compound 5ka in $\mathrm{CDCl}_{3}, 400 \mathrm{MHz}$

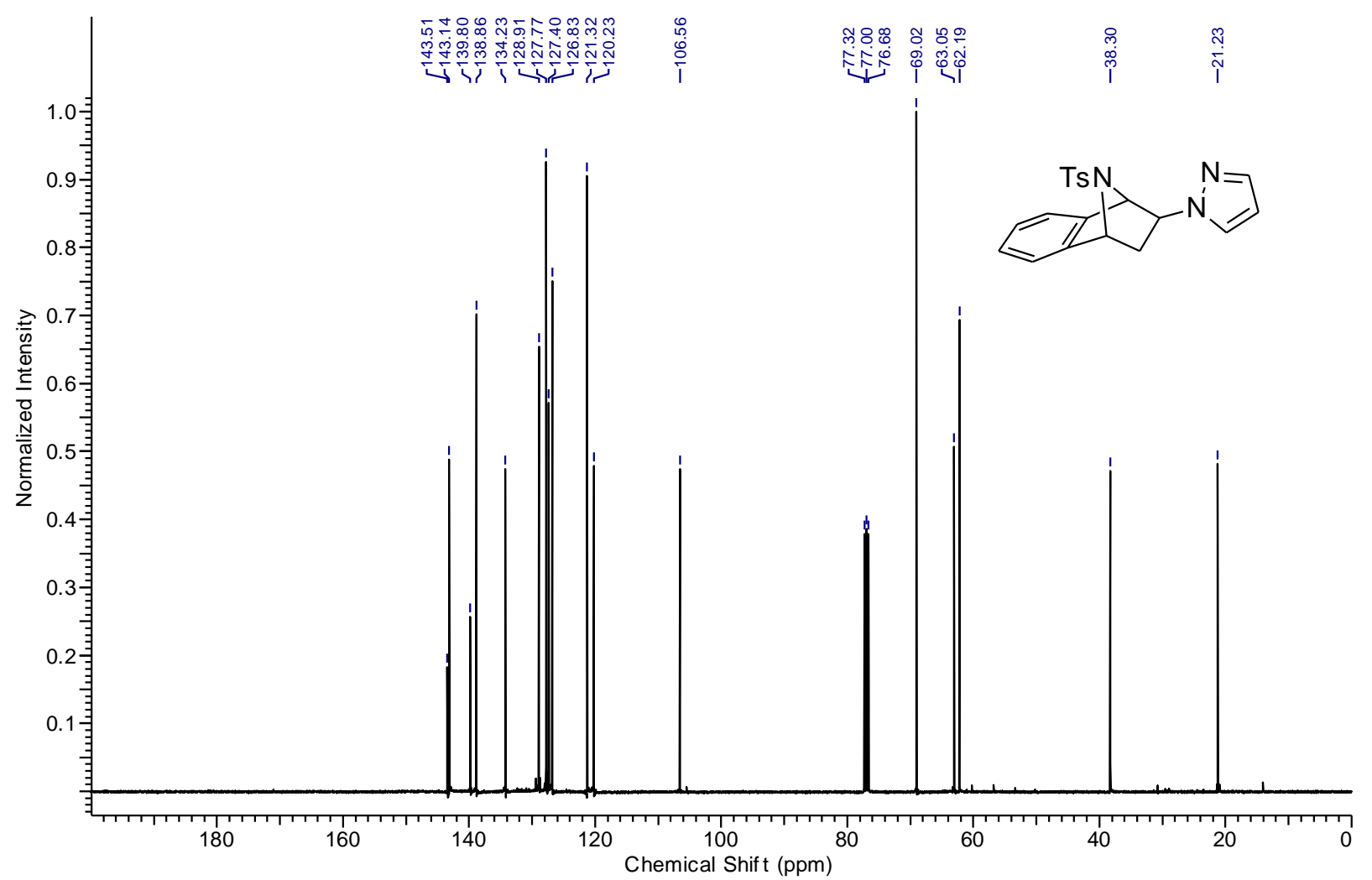

Figure S60. ${ }^{13} \mathrm{C}\left\{{ }^{1} \mathrm{H}\right\}$ NMR spectrum of the compound 5ka in $\mathrm{CDCl}_{3}, 100 \mathrm{MHz}$ 


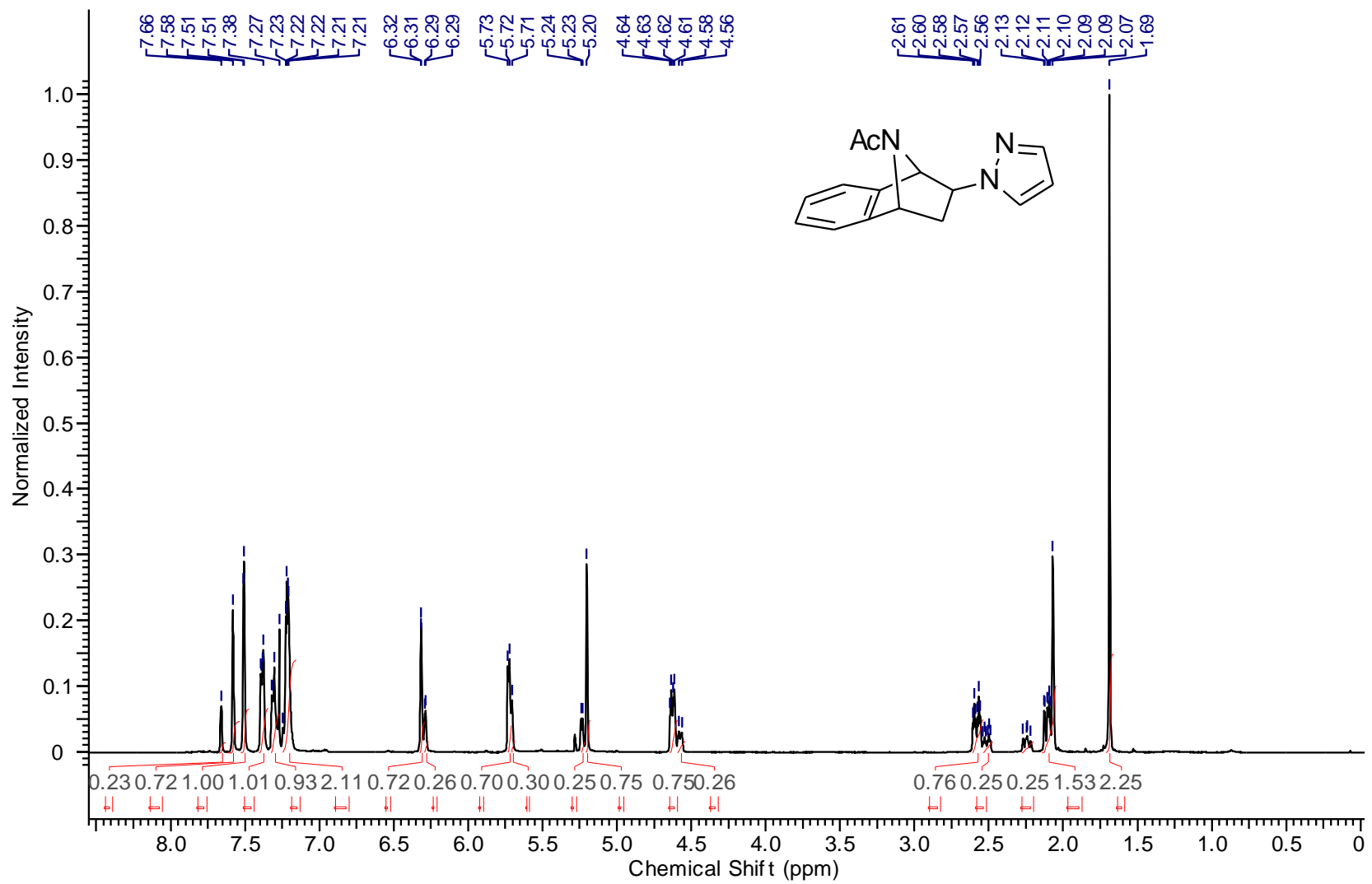

Figure 61. ${ }^{1} \mathrm{H}$ NMR spectrum of the compound 5la (a 3:1 mixture of rotamers) in $\mathrm{CDCl}_{3}, 400 \mathrm{MHz}$

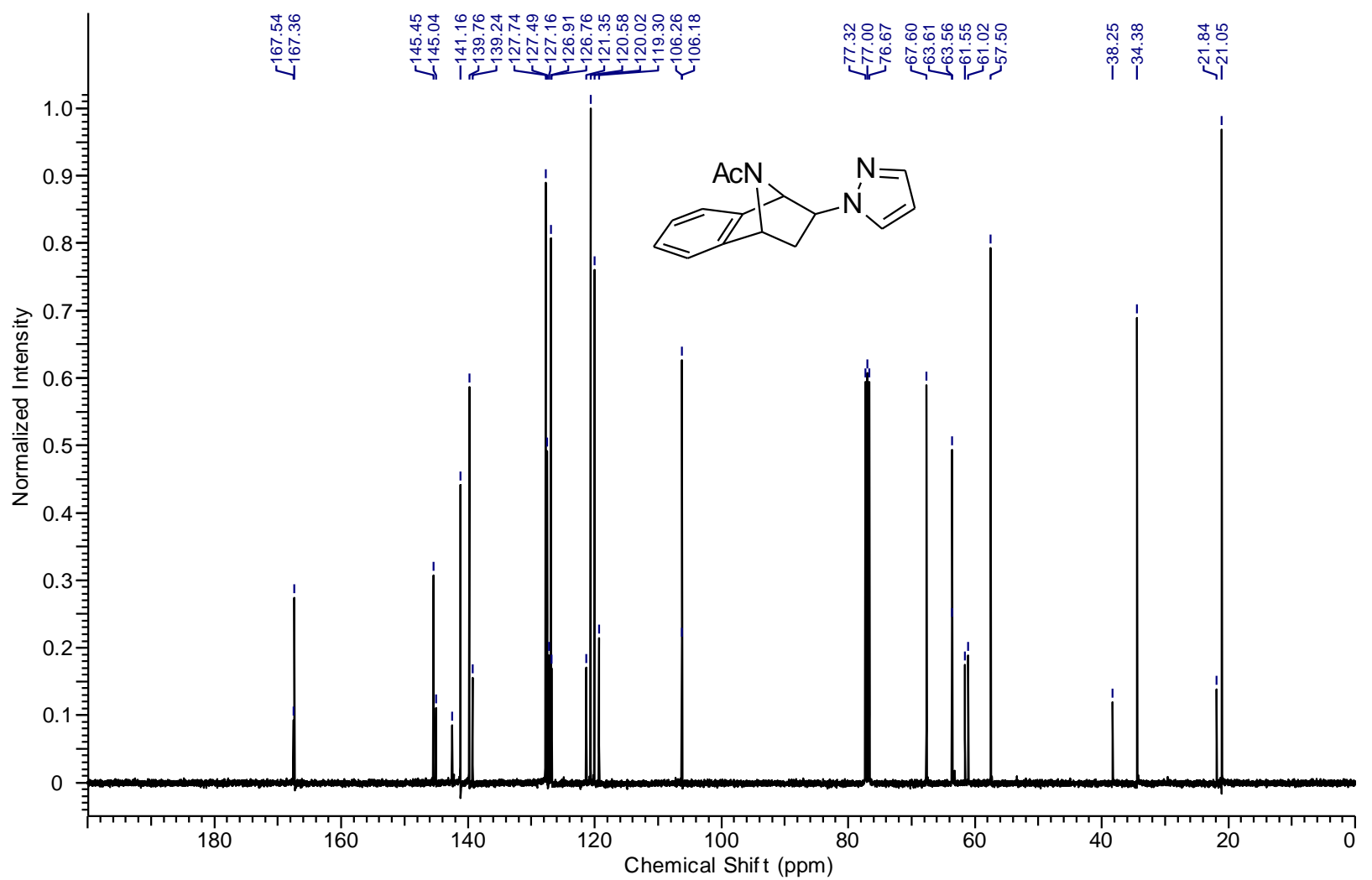

Figure S62. ${ }^{13} \mathrm{C}\left\{{ }^{1} \mathrm{H}\right\}$ NMR spectrum of the compound 5la (a 3:1 mixture of rotamers) in $\mathrm{CDCl}_{3}, 100$ $\mathrm{MHz}$ 


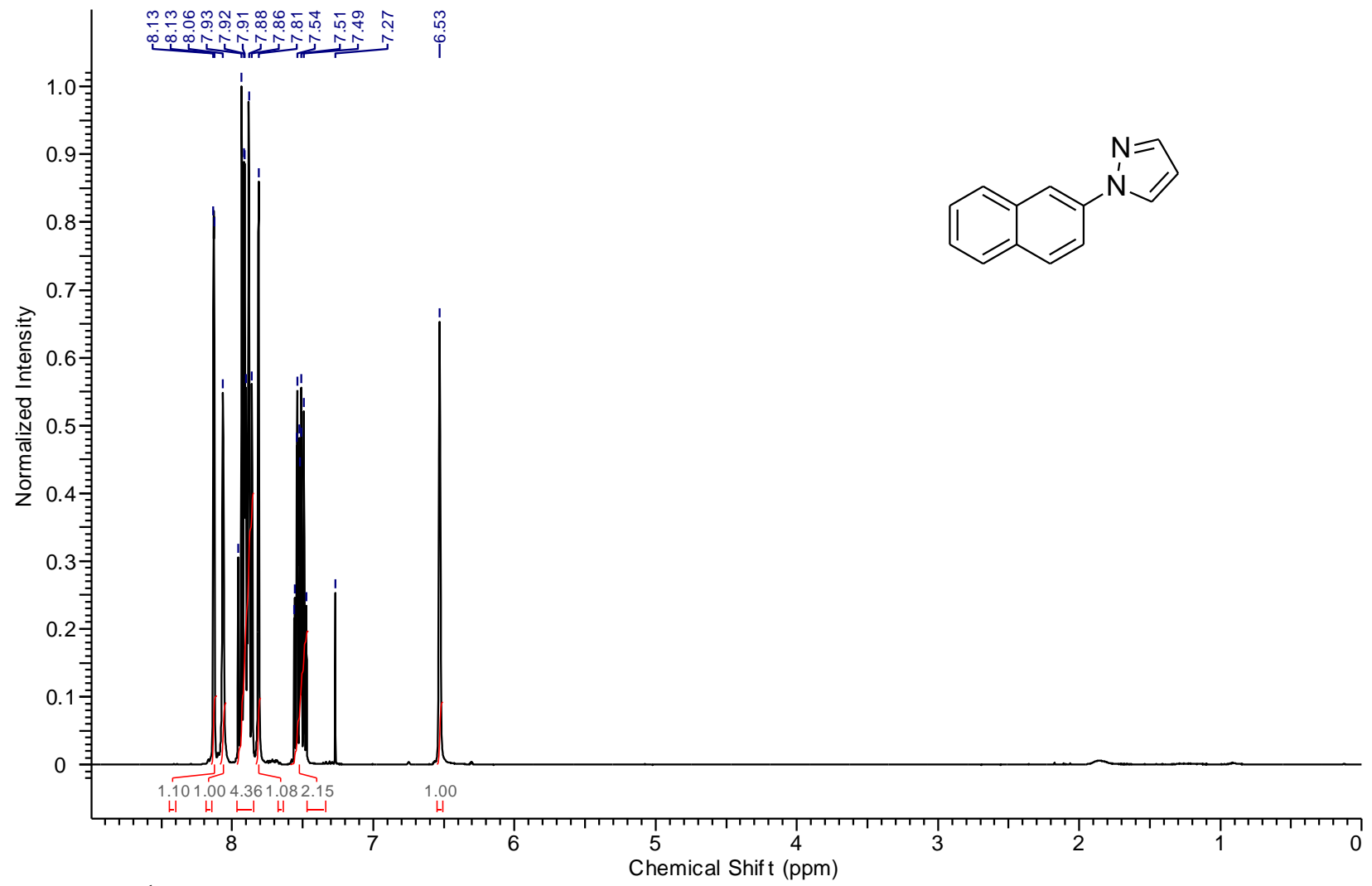

Figure S63. ${ }^{1} \mathrm{H}$ NMR spectrum of the compound $\mathbf{6 a}$ in $\mathrm{CDCl}_{3}, 400 \mathrm{MHz}$

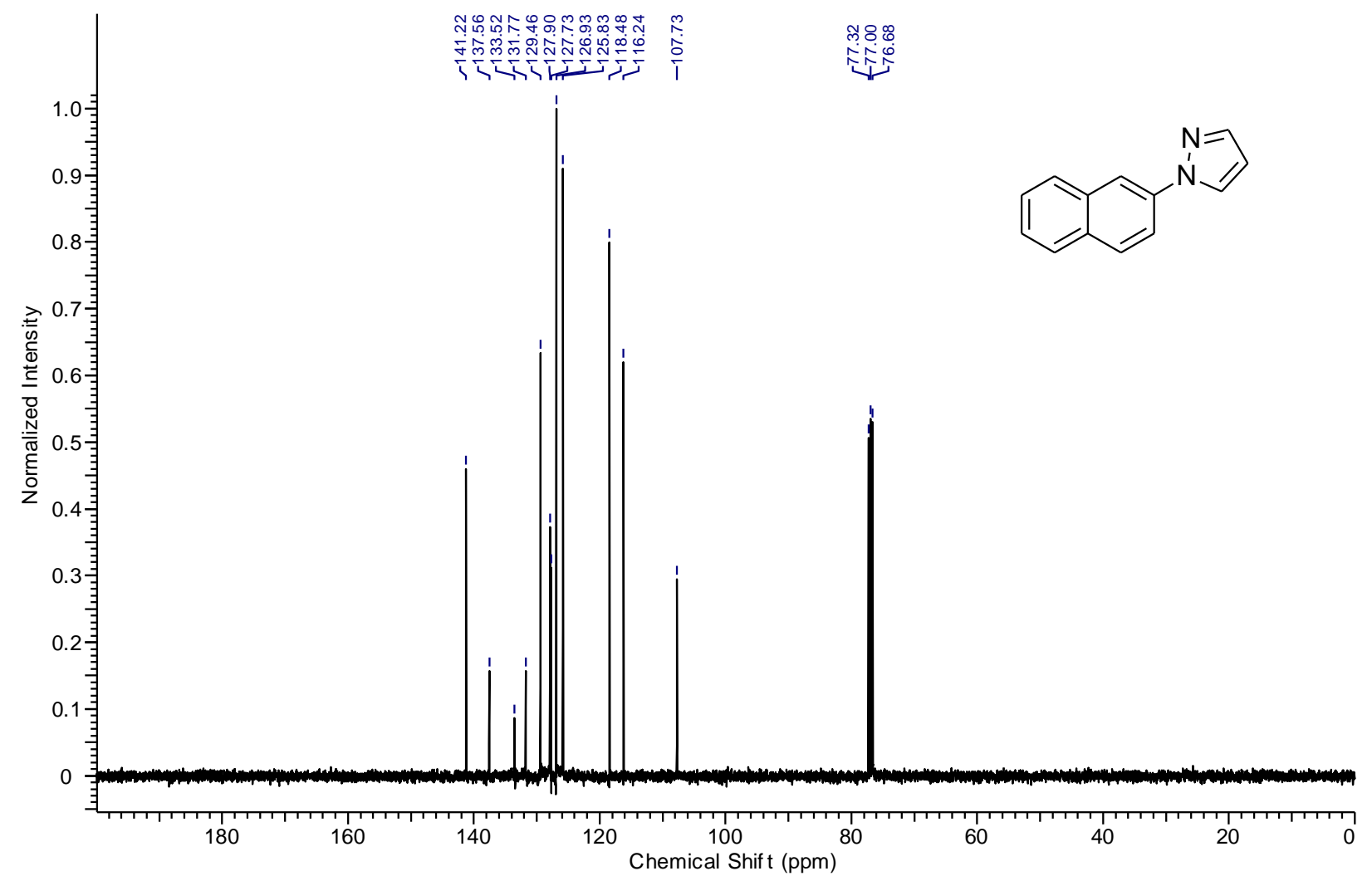

Figure S64. ${ }^{13} \mathrm{C}\left\{{ }^{1} \mathrm{H}\right\}$ NMR spectrum of the compound $\mathbf{6 a}$ in $\mathrm{CDCl}_{3}, 100 \mathrm{MHz}$ 


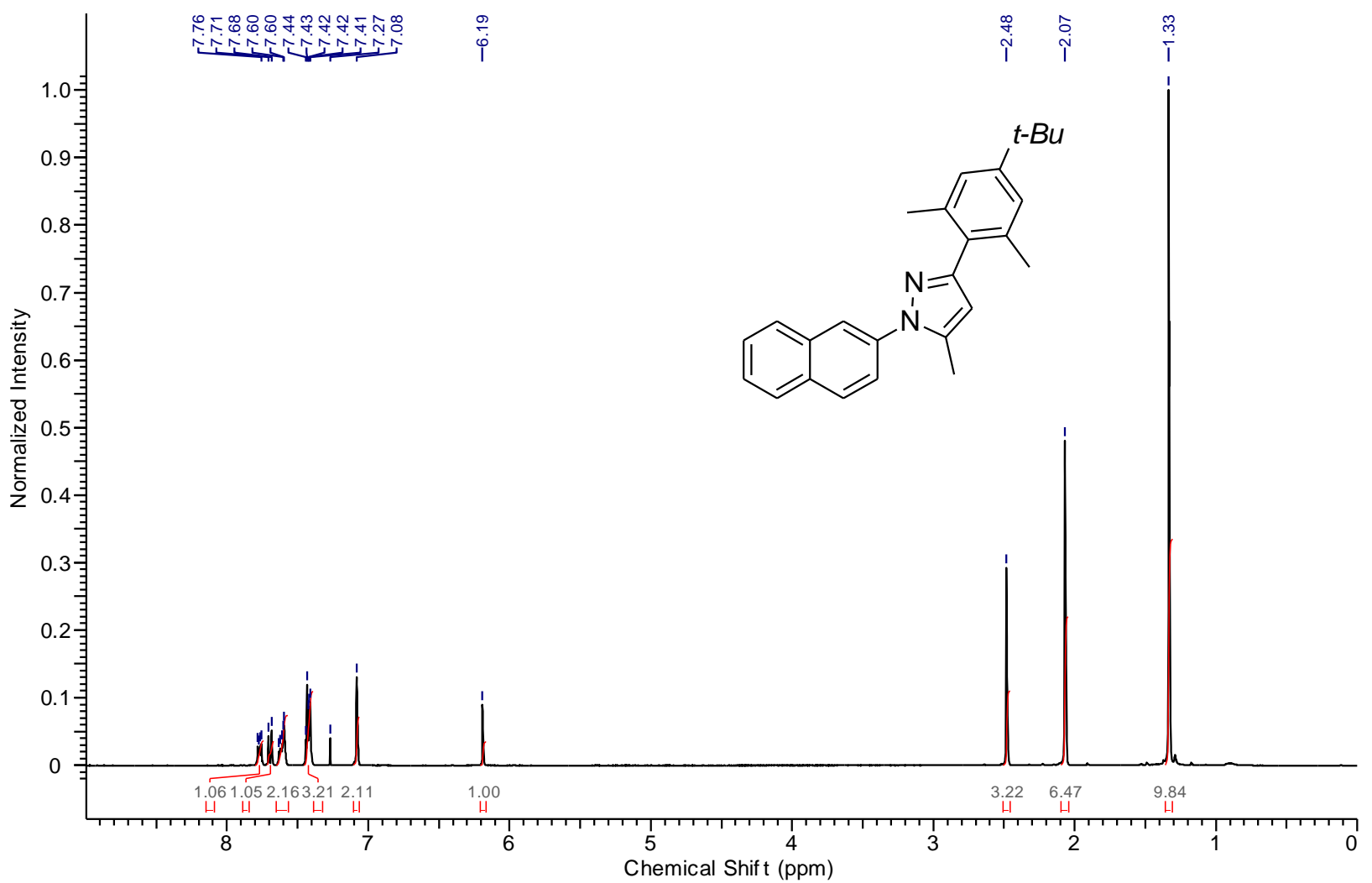

Figure S65. ${ }^{1} \mathrm{H}$ NMR spectrum of the compound $\mathbf{6 b}$ in $\mathrm{CDCl}_{3}, 400 \mathrm{MHz}$

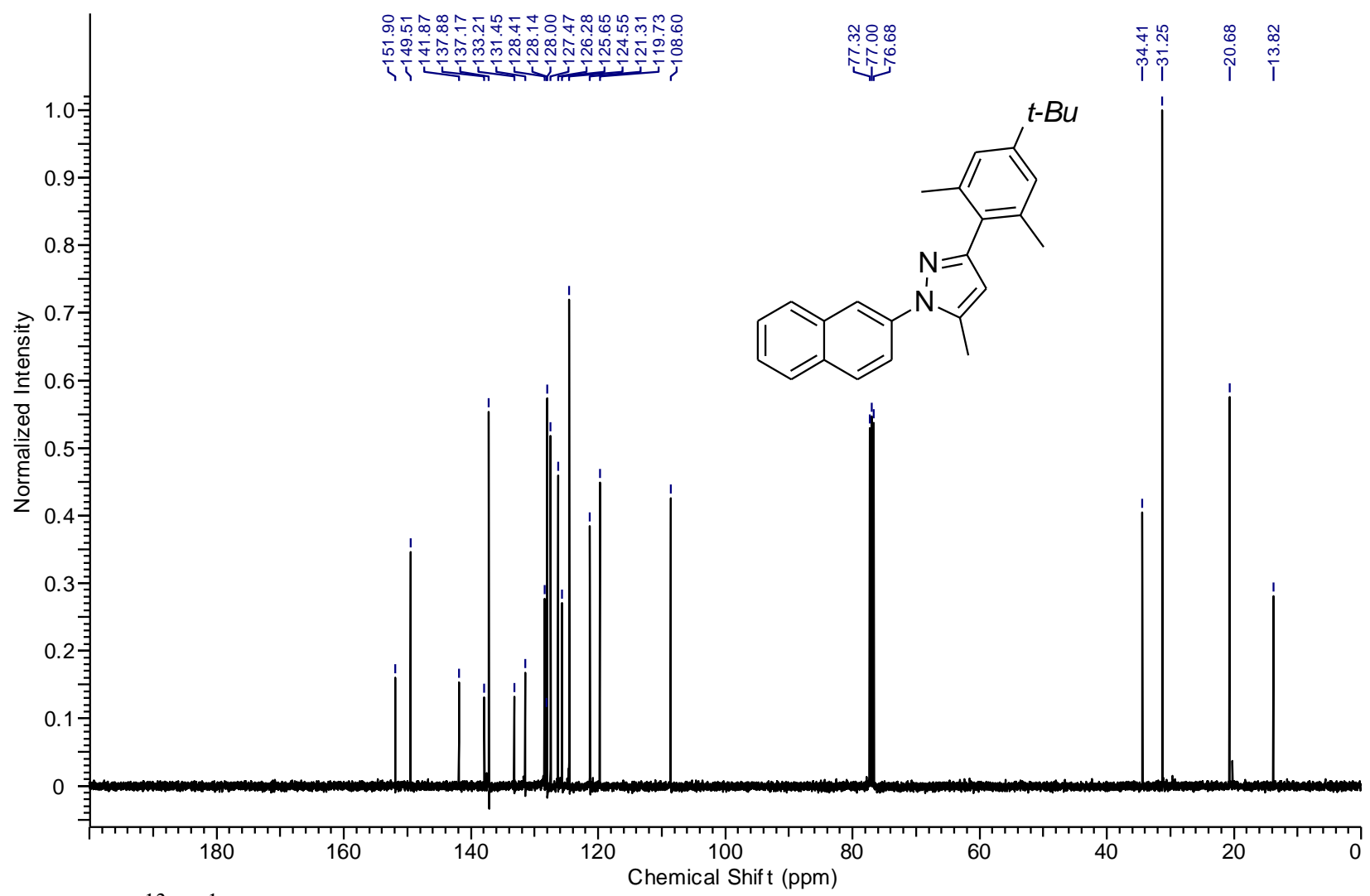

Figure S66. ${ }^{13} \mathrm{C}\left\{{ }^{1} \mathrm{H}\right\}$ NMR spectrum of the compound $\mathbf{6 b}$ in $\mathrm{CDCl}_{3}, 100 \mathrm{MHz}$ 


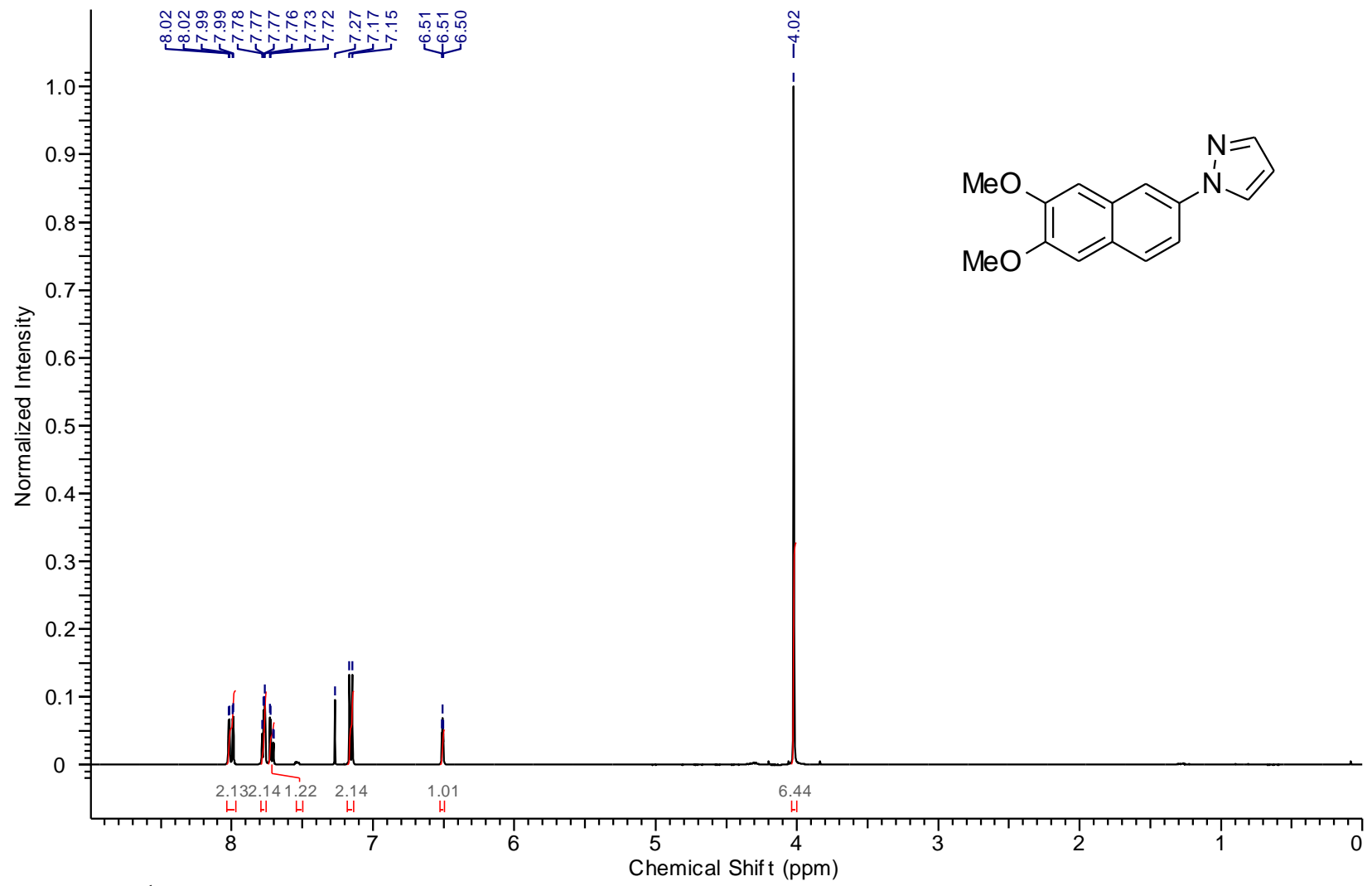

Figure S67. ${ }^{1} \mathrm{H} \mathrm{NMR}$ spectrum of the compound $\mathbf{6 c}$ in $\mathrm{CDCl}_{3}, 400 \mathrm{MHz}$

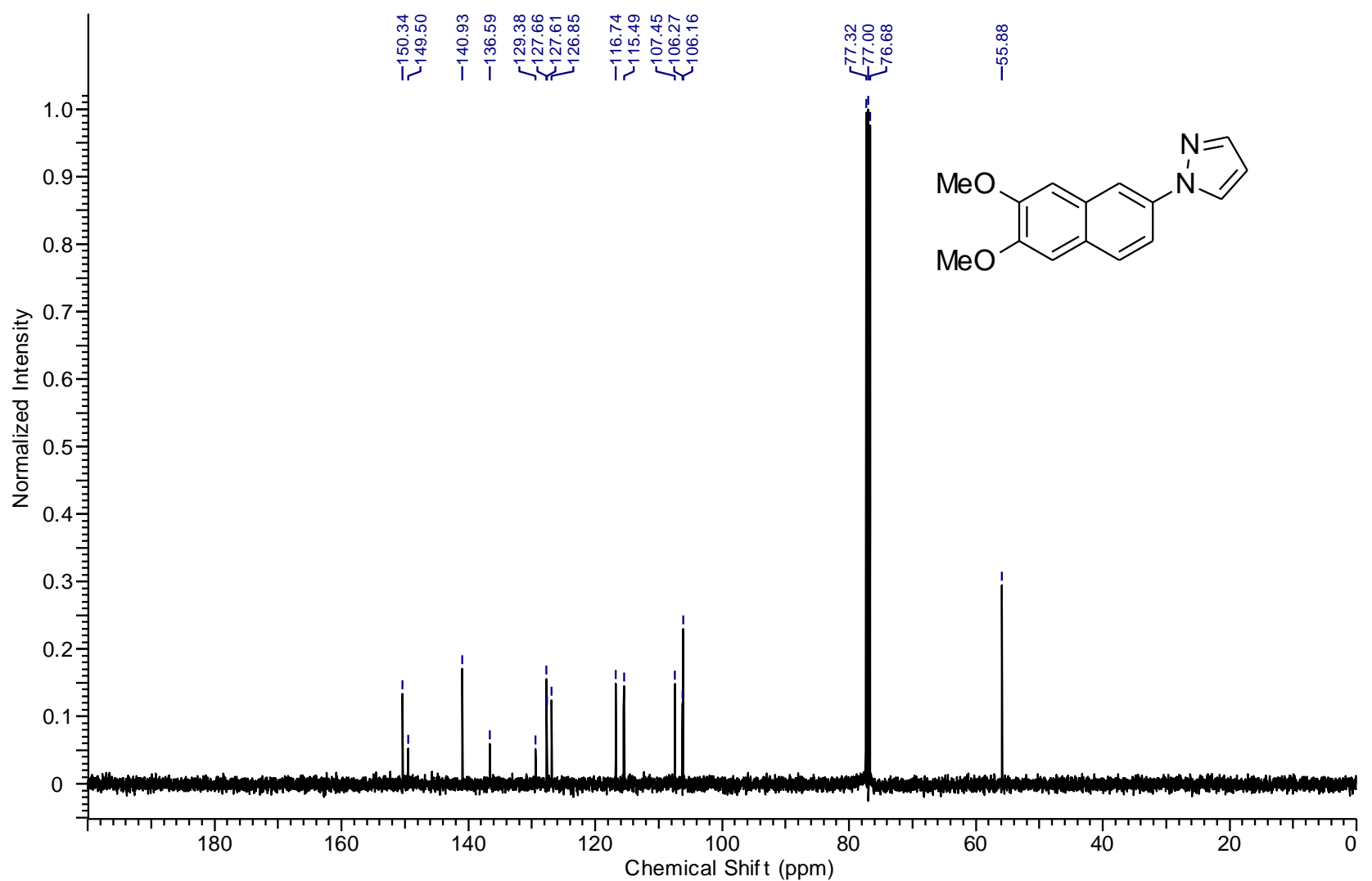

Figure S68. ${ }^{13} \mathrm{C}\left\{{ }^{1} \mathrm{H}\right\}$ NMR spectrum of the compound $\mathbf{6 c}$ in $\mathrm{CDCl}_{3}, 100 \mathrm{MHz}$ 


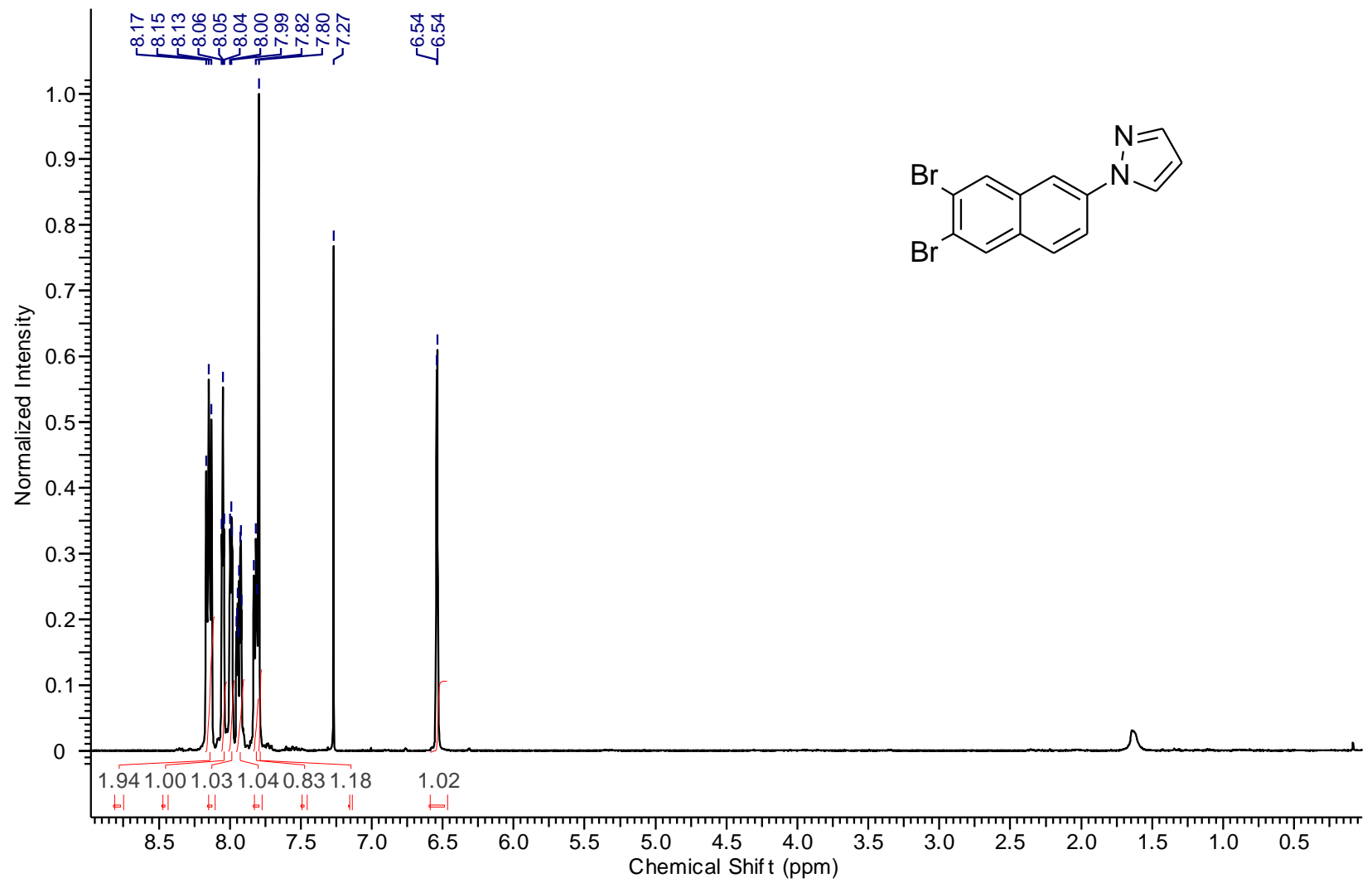

Figure S69. ${ }^{1} \mathrm{H}$ NMR spectrum of the compound $\mathbf{6 d}$ in $\mathrm{CDCl}_{3}, 400 \mathrm{MHz}$

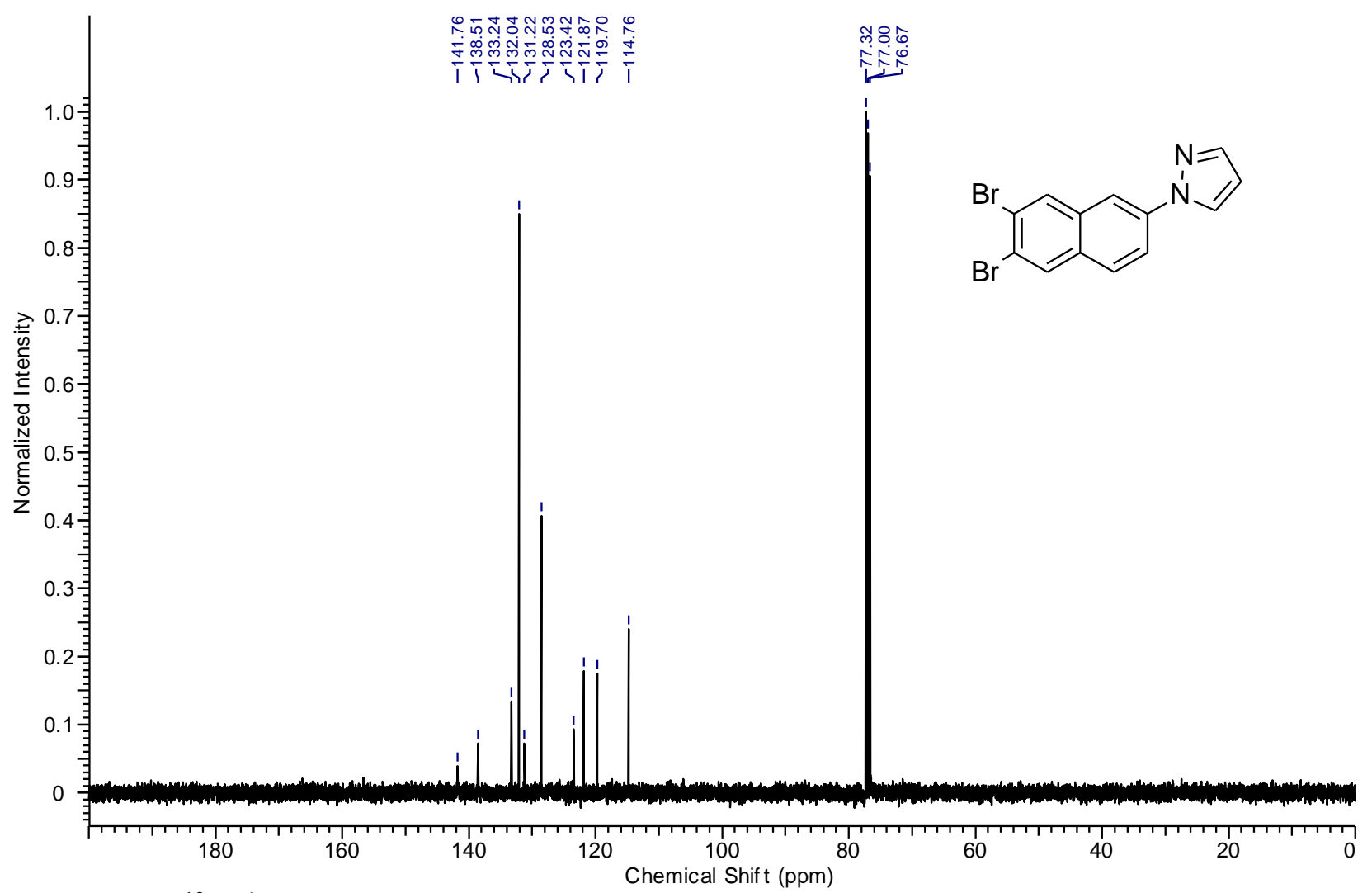

Figure S70. ${ }^{13} \mathrm{C}\left\{{ }^{1} \mathrm{H}\right\}$ NMR spectrum of the compound $\mathbf{6 d}$ in $\mathrm{CDCl}_{3}, 100 \mathrm{MHz}$ 
2D-NOESY proton NMR spectra of compound $3 \mathrm{ca}, 3 \mathrm{cb}, 3 \mathrm{~h}$ and $1 \mathrm{H}$ NOESY correlations

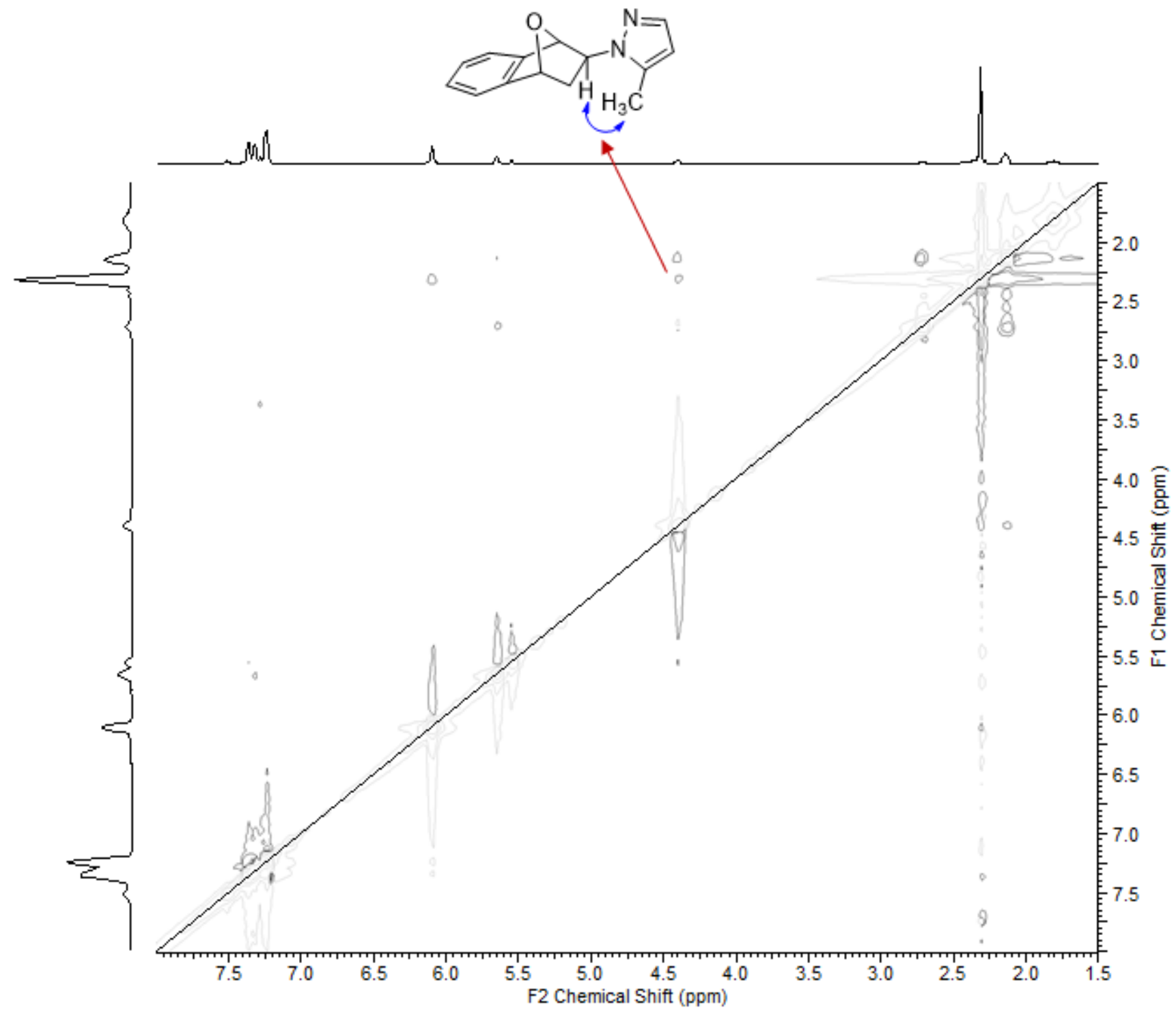

Figure S71. 2D-NOESY spectrum of the compound $3 \mathbf{c a}$ in $\mathrm{CDCl}_{3}$ 


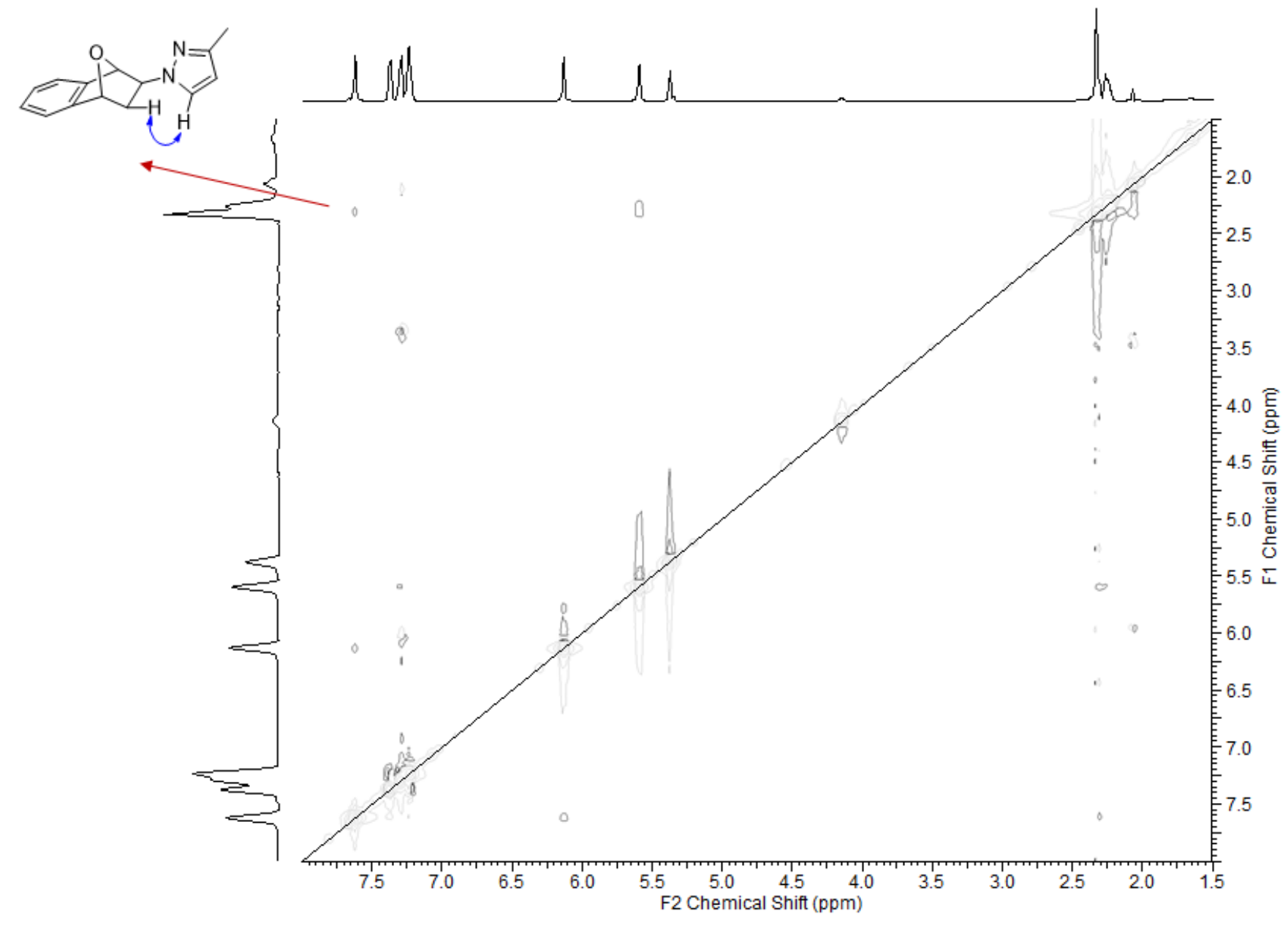

Figure S72. 2D-NOESY spectrum of the compound $\mathbf{3 c b}$ in $\mathrm{CDCl}_{3}$ 


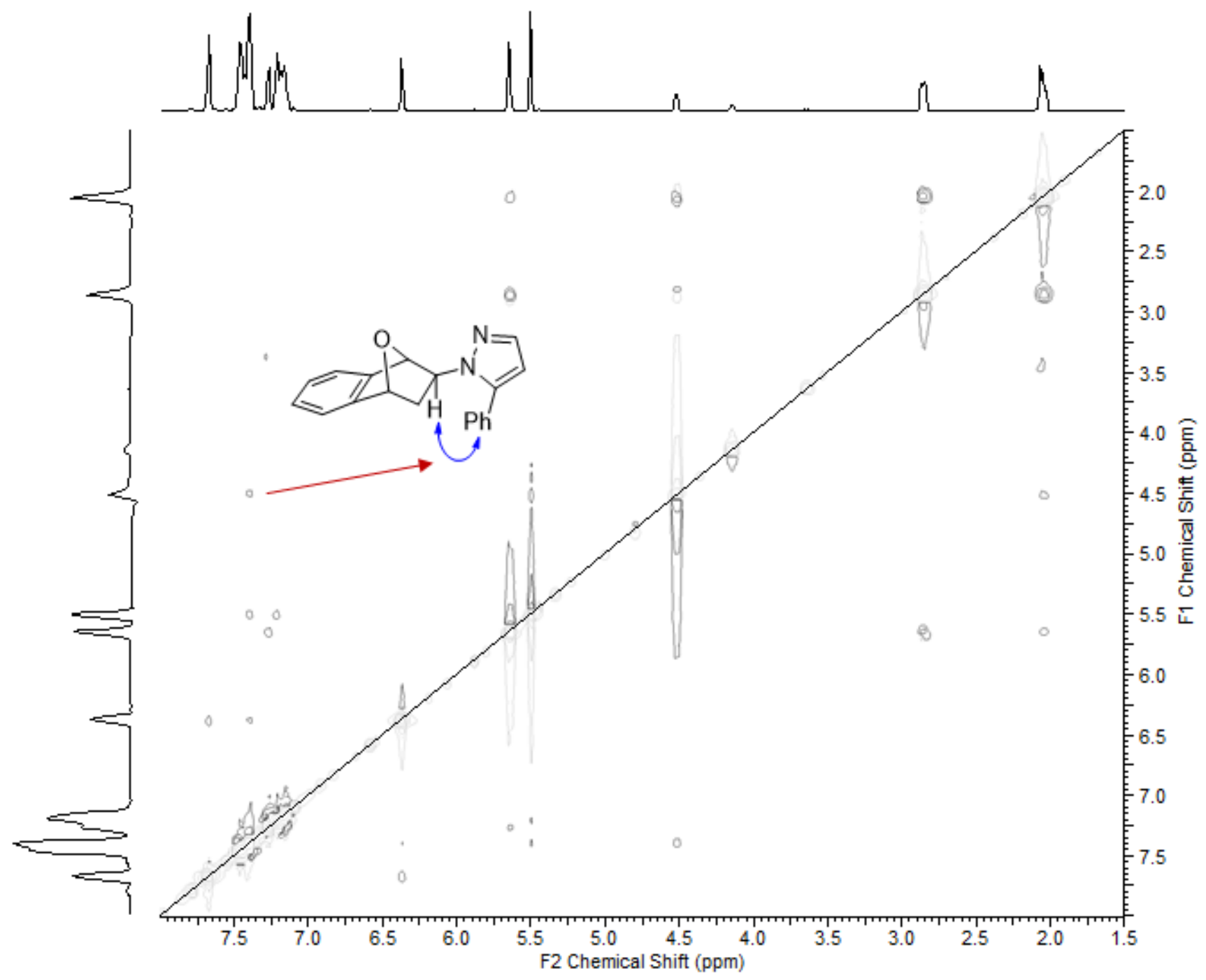

Figure S73. 2D-NOESY spectrum of the compound $\mathbf{3 h}$ in $\mathrm{CDCl}_{3}$ 


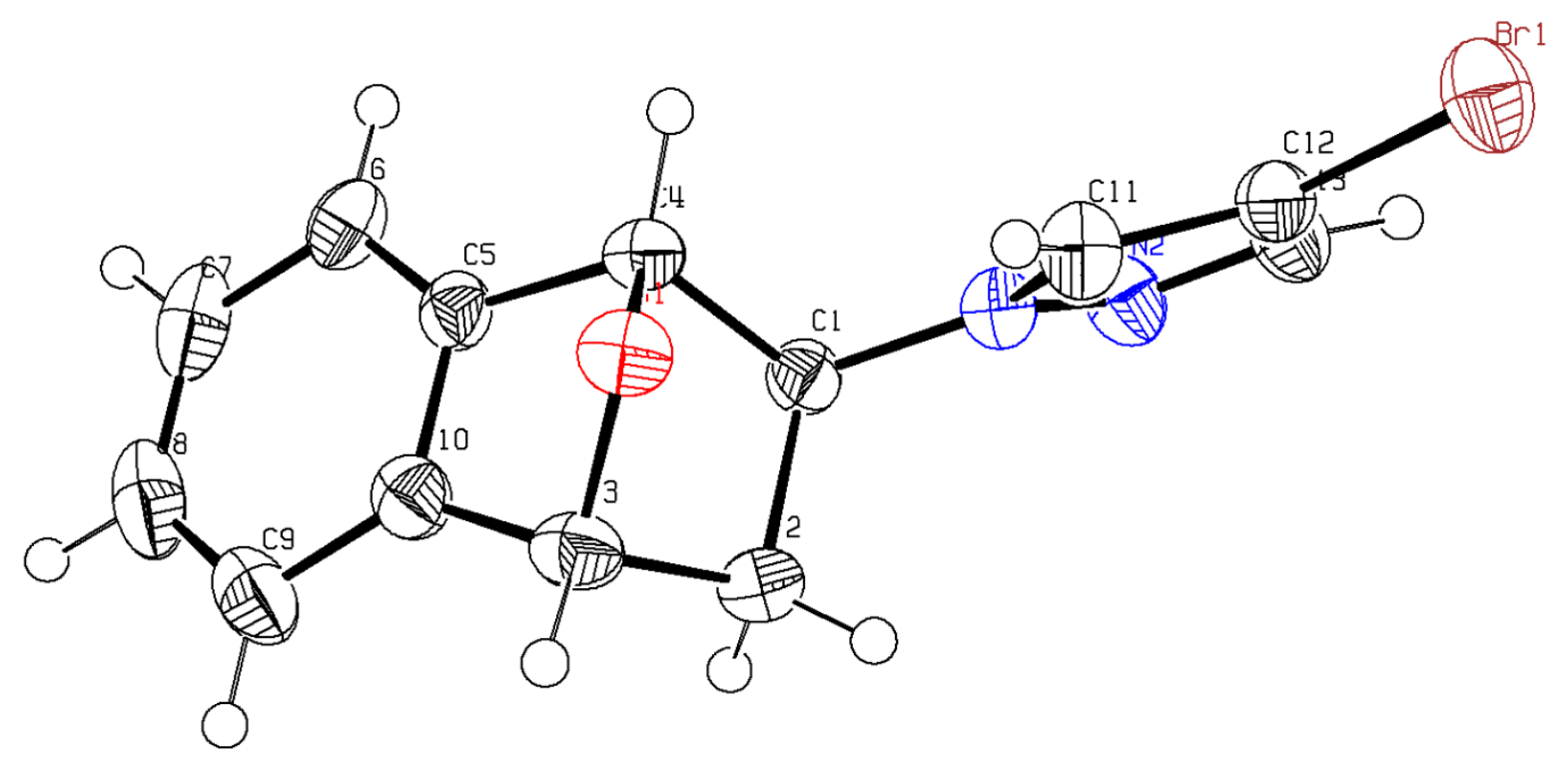

Figure S74. Thermal ellipsoid (50\% probability) plot of 3d

X-ray structural Analyses. Crystals were obtained by the slow diffusion method from a mixture of $\mathrm{CH}_{2} \mathrm{Cl}_{2}$ and hexanes at $0{ }^{\circ} \mathrm{C}$ (refrigerator). The crystal structure of $\mathbf{3 d}$ was determined by standard crystallographic method. A colorless block-shaped crystal $\left(0.05 \times 0.09 \times 0.19 \mathrm{~mm}^{3}\right)$ was used for singlecrystal X-ray diffraction. The data were collected at 223(2) K using a Bruker D8 Venture equipped with $\mathrm{I} \mu \mathrm{S}$ micro-focus sealed tube Mo K $\alpha(\lambda=0.71073 \AA)$ and a PHOTON III M14 detector in Western Seoul Center of Korea Basic Science Institute. Data collection and integration were performed with SMART APEX3 software package (SAINT+). ${ }^{[1]}$ Absorption correction was performed by multi-scan method implemented in SADABS. ${ }^{[2]}$ The structure was solved by direct methods and refined by full-matrix leastsquares on $F^{2}$ using SHELXTL program package (version 6.14). ${ }^{[3]}$ All the non-hydrogen atoms were refined anisotropically, and hydrogen atoms were added to their geometrically ideal positions.

Crystallographic data and structural refinements are described in Table S1. The final refined atomic positions and structural parameters are summarized in the Tables S2-S6. The crystal data of 3d have been deposited in CCDC with number 2110511. 
[1] SMART, SAINT and SADABS, Bruker AXS Inc., Madison, Wisconsin, USA, 2012.

[2] G. M. Sheldrick, SADABS v 2.03, University of Göttingen, Germany, 2002.

[3] SHELXTL v 6.10; Bruker AXS, Inc: Madison, Wisconsin, USA, 2000.

Table S1. Crystal data and structure refinement for $\mathbf{3 d}$.

\begin{tabular}{|c|c|c|}
\hline Identification code & \multicolumn{2}{|l|}{ 3d } \\
\hline Empirical formula & \multicolumn{2}{|l|}{$\mathrm{C}_{13} \mathrm{H}_{11} \mathrm{Br} \mathrm{N}_{2} \mathrm{O}$} \\
\hline Formula weight & \multicolumn{2}{|l|}{291.15} \\
\hline Temperature & \multicolumn{2}{|l|}{$223(2) \mathrm{K}$} \\
\hline Wavelength & \multicolumn{2}{|l|}{$0.71073 \AA$} \\
\hline Crystal system & \multicolumn{2}{|l|}{ Triclinic } \\
\hline Space group & \multicolumn{2}{|l|}{$\mathrm{P}-1$} \\
\hline \multirow[t]{3}{*}{ Unit cell dimensions } & $\mathrm{a}=7.3786(18) \AA$ & $\alpha=84.505(13)^{\circ}$. \\
\hline & $\mathrm{b}=9.014(2) \AA$ & $\beta=77.225(8)^{\circ}$ \\
\hline & $c=9.2011(19) \AA$ & $\gamma=77.353(13)^{\circ}$. \\
\hline Volume & \multicolumn{2}{|l|}{$581.6(2) \AA^{3}$} \\
\hline $\mathrm{Z}$ & \multicolumn{2}{|l|}{2} \\
\hline Density (calculated) & \multicolumn{2}{|l|}{$1.662 \mathrm{Mg} / \mathrm{m}^{3}$} \\
\hline Absorption coefficient & \multicolumn{2}{|l|}{$3.517 \mathrm{~mm}^{-1}$} \\
\hline $\mathrm{F}(000)$ & \multicolumn{2}{|c|}{292} \\
\hline Crystal size & \multicolumn{2}{|c|}{$0.192 \times 0.087 \times 0.047 \mathrm{~mm}^{3}$} \\
\hline Theta range for data collection & \multicolumn{2}{|l|}{2.319 to $28.430^{\circ}$. } \\
\hline Index ranges & \multicolumn{2}{|c|}{$-9<=\mathrm{h}<=9,-12<=\mathrm{k}<=12,-12<=\mathrm{l}<=12$} \\
\hline Reflections collected & \multicolumn{2}{|l|}{17447} \\
\hline Independent reflections & \multicolumn{2}{|c|}{$2906[\mathrm{R}(\mathrm{int})=0.0308]$} \\
\hline Completeness to theta $=25.242^{\circ}$ & \multicolumn{2}{|c|}{$100.0 \%$} \\
\hline Absorption correction & \multicolumn{2}{|c|}{ Semi-empirical from equivalents } \\
\hline Max. and min. transmission & \multicolumn{2}{|l|}{0.7457 and 0.5955} \\
\hline Refinement method & \multicolumn{2}{|c|}{ Full-matrix least-squares on $\mathrm{F}^{2}$} \\
\hline Data / restraints / parameters & \multicolumn{2}{|l|}{$2906 / 0 / 154$} \\
\hline Goodness-of-fit on $\mathrm{F}^{2}$ & \multicolumn{2}{|l|}{1.043} \\
\hline Final $R$ indices $[\mathrm{I}>2 \operatorname{sigma}(\mathrm{I})]$ & \multicolumn{2}{|c|}{$\mathrm{R} 1=0.0270, \mathrm{wR} 2=0.0553$} \\
\hline $\mathrm{R}$ indices (all data) & \multicolumn{2}{|c|}{$\mathrm{R} 1=0.0369, \mathrm{wR} 2=0.0585$} \\
\hline Extinction coefficient & \multicolumn{2}{|l|}{$\mathrm{n} / \mathrm{a}$} \\
\hline Largest diff. peak and hole & \multicolumn{2}{|c|}{0.344 and -0.302 e. $\AA^{-3}$} \\
\hline
\end{tabular}


Table S2. Atomic coordinates ( x 104) and equivalent isotropic displacement parameters $\left(\AA^{2} \times 10^{3}\right)$ for 3d. $U(e q)$ is defined as one third of the trace of the orthogonalized Uij tensor.

\begin{tabular}{lrccc}
\hline & $\mathrm{x}$ & $\mathrm{y}$ & $\mathrm{z}$ & $\mathrm{U}(\mathrm{eq})$ \\
\hline $\mathrm{C}(1)$ & $3089(3)$ & $5735(2)$ & $8181(2)$ & $29(1)$ \\
$\mathrm{C}(2)$ & $1044(3)$ & $6550(2)$ & $8039(2)$ & $35(1)$ \\
$\mathrm{C}(3)$ & $740(3)$ & $5724(2)$ & $6742(2)$ & $35(1)$ \\
$\mathrm{O}(1)$ & $2634(2)$ & $5485(2)$ & $5797(1)$ & $34(1)$ \\
$\mathrm{C}(4)$ & $3602(3)$ & $4610(2)$ & $6910(2)$ & $29(1)$ \\
$\mathrm{C}(5)$ & $2435(3)$ & $3397(2)$ & $7412(2)$ & $30(1)$ \\
$\mathrm{C}(6)$ & $2850(3)$ & $1908(2)$ & $7940(2)$ & $37(1)$ \\
$\mathrm{C}(7)$ & $1352(4)$ & $1138(3)$ & $8359(2)$ & $47(1)$ \\
$\mathrm{C}(8)$ & $-468(4)$ & $1851(3)$ & $8271(2)$ & $50(1)$ \\
$\mathrm{C}(9)$ & $-892(3)$ & $3364(3)$ & $7752(2)$ & $44(1)$ \\
$\mathrm{C}(10)$ & $596(3)$ & $4121(2)$ & $7300(2)$ & $33(1)$ \\
$\mathrm{N}(1)$ & $4398(2)$ & $6779(2)$ & $7946(2)$ & $29(1)$ \\
$\mathrm{N}(2)$ & $5006(2)$ & $7139(2)$ & $9124(2)$ & $35(1)$ \\
$\mathrm{C}(11)$ & $7511(2)$ & $6668(2)$ & $34(1)$ \\
$\mathrm{C}(12)$ & $8377(2)$ & $7025(2)$ & $30(1)$ \\
$\mathrm{C}(13)$ & $8102(3)$ & $8547(2)$ & $36(1)$ \\
$\mathrm{Br}(1)$ & $6225(3)$ & $5625(1)$ & $5728(1)$ & $44(1)$ \\
& & & \\
\hline
\end{tabular}


Table S3. Bond lengths $[\AA]$ and angles $\left[{ }^{\circ}\right]$ for $\mathbf{3 d}$.

\begin{tabular}{|c|c|}
\hline Bond lengths & $\AA$ \\
\hline $\mathrm{C}(1)-\mathrm{N}(1)$ & $1.460(2)$ \\
\hline $\mathrm{C}(1)-\mathrm{C}(4)$ & $1.550(2)$ \\
\hline $\mathrm{C}(1)-\mathrm{C}(2)$ & $1.555(3)$ \\
\hline $\mathrm{C}(1)-\mathrm{H}(1)$ & 0.99 \\
\hline $\mathrm{C}(2)-\mathrm{C}(3)$ & $1.546(3)$ \\
\hline $\mathrm{C}(2)-\mathrm{H}(2 \mathrm{~A})$ & 0.98 \\
\hline $\mathrm{C}(2)-\mathrm{H}(2 \mathrm{~B})$ & 0.98 \\
\hline $\mathrm{C}(3)-\mathrm{O}(1)$ & $1.457(2)$ \\
\hline $\mathrm{C}(3)-\mathrm{C}(10)$ & $1.505(3)$ \\
\hline $\mathrm{C}(3)-\mathrm{H}(3)$ & 0.99 \\
\hline $\mathrm{O}(1)-\mathrm{C}(4)$ & $1.450(2)$ \\
\hline$C(4)-C(5)$ & $1.513(3)$ \\
\hline $\mathrm{C}(4)-\mathrm{H}(4)$ & 0.99 \\
\hline $\mathrm{C}(5)-\mathrm{C}(6)$ & $1.376(3)$ \\
\hline $\mathrm{C}(5)-\mathrm{C}(10)$ & $1.393(3)$ \\
\hline $\mathrm{C}(6)-\mathrm{C}(7)$ & $1.396(3)$ \\
\hline $\mathrm{C}(6)-\mathrm{H}(6)$ & 0.94 \\
\hline $\mathrm{C}(7)-\mathrm{C}(8)$ & $1.373(3)$ \\
\hline $\mathrm{C}(7)-\mathrm{H}(7)$ & 0.94 \\
\hline $\mathrm{C}(8)-\mathrm{C}(9)$ & $1.393(3)$ \\
\hline $\mathrm{C}(8)-\mathrm{H}(8)$ & 0.94 \\
\hline $\mathrm{C}(9)-\mathrm{C}(10)$ & $1.384(3)$ \\
\hline $\mathrm{C}(9)-\mathrm{H}(9)$ & 0.94 \\
\hline $\mathrm{N}(1)-\mathrm{C}(11)$ & $1.350(2)$ \\
\hline $\mathrm{N}(1)-\mathrm{N}(2)$ & $1.352(2)$ \\
\hline $\mathrm{N}(2)-\mathrm{C}(13)$ & $1.334(2)$ \\
\hline $\mathrm{C}(11)-\mathrm{C}(12)$ & $1.362(3)$ \\
\hline $\mathrm{C}(11)-\mathrm{H}(11)$ & 0.94 \\
\hline $\mathrm{C}(12)-\mathrm{C}(13)$ & $1.386(3)$ \\
\hline $\mathrm{C}(12)-\operatorname{Br}(1)$ & $1.8708(18)$ \\
\hline $\mathrm{C}(13)-\mathrm{H}(13)$ & 0.94 \\
\hline $\mathrm{N}(1)-\mathrm{C}(1)-\mathrm{C}(4)$ & $111.40(14)$ \\
\hline $\mathrm{N}(1)-\mathrm{C}(1)-\mathrm{C}(2)$ & $112.70(15)$ \\
\hline $\mathrm{C}(4)-\mathrm{C}(1)-\mathrm{C}(2)$ & $100.97(14)$ \\
\hline $\mathrm{N}(1)-\mathrm{C}(1)-\mathrm{H}(1)$ & 110.5 \\
\hline $\mathrm{C}(4)-\mathrm{C}(1)-\mathrm{H}(1)$ & 110.5 \\
\hline $\mathrm{C}(2)-\mathrm{C}(1)-\mathrm{H}(1)$ & 110.5 \\
\hline
\end{tabular}




\begin{tabular}{|c|c|}
\hline $\mathrm{C}(3)-\mathrm{C}(2)-\mathrm{C}(1)$ & $101.68(14)$ \\
\hline $\mathrm{C}(3)-\mathrm{C}(2)-\mathrm{H}(2 \mathrm{~A})$ & 111.4 \\
\hline $\mathrm{C}(1)-\mathrm{C}(2)-\mathrm{H}(2 \mathrm{~A})$ & 111.4 \\
\hline $\mathrm{C}(3)-\mathrm{C}(2)-\mathrm{H}(2 \mathrm{~B})$ & 111.4 \\
\hline $\mathrm{C}(1)-\mathrm{C}(2)-\mathrm{H}(2 \mathrm{~B})$ & 111.4 \\
\hline $\mathrm{H}(2 \mathrm{~A})-\mathrm{C}(2)-\mathrm{H}(2 \mathrm{~B})$ & 109.3 \\
\hline $\mathrm{O}(1)-\mathrm{C}(3)-\mathrm{C}(10)$ & $101.37(15)$ \\
\hline $\mathrm{O}(1)-\mathrm{C}(3)-\mathrm{C}(2)$ & $100.95(15)$ \\
\hline $\mathrm{C}(10)-\mathrm{C}(3)-\mathrm{C}(2)$ & $107.65(16)$ \\
\hline $\mathrm{O}(1)-\mathrm{C}(3)-\mathrm{H}(3)$ & 115 \\
\hline $\mathrm{C}(10)-\mathrm{C}(3)-\mathrm{H}(3)$ & 115 \\
\hline $\mathrm{C}(2)-\mathrm{C}(3)-\mathrm{H}(3)$ & 115 \\
\hline $\mathrm{C}(4)-\mathrm{O}(1)-\mathrm{C}(3)$ & $96.17(13)$ \\
\hline $\mathrm{O}(1)-\mathrm{C}(4)-\mathrm{C}(5)$ & $101.44(14)$ \\
\hline $\mathrm{O}(1)-\mathrm{C}(4)-\mathrm{C}(1)$ & $101.82(14)$ \\
\hline $\mathrm{C}(5)-\mathrm{C}(4)-\mathrm{C}(1)$ & 106.91(14) \\
\hline $\mathrm{O}(1)-\mathrm{C}(4)-\mathrm{H}(4)$ & 115 \\
\hline $\mathrm{C}(5)-\mathrm{C}(4)-\mathrm{H}(4)$ & 115 \\
\hline $\mathrm{C}(1)-\mathrm{C}(4)-\mathrm{H}(4)$ & 115 \\
\hline $\mathrm{C}(6)-\mathrm{C}(5)-\mathrm{C}(10)$ & $121.75(18)$ \\
\hline $\mathrm{C}(6)-\mathrm{C}(5)-\mathrm{C}(4)$ & $133.65(18)$ \\
\hline$C(10)-C(5)-C(4)$ & $104.56(16)$ \\
\hline $\mathrm{C}(5)-\mathrm{C}(6)-\mathrm{C}(7)$ & $117.4(2)$ \\
\hline $\mathrm{C}(5)-\mathrm{C}(6)-\mathrm{H}(6)$ & 121.3 \\
\hline $\mathrm{C}(7)-\mathrm{C}(6)-\mathrm{H}(6)$ & 121.3 \\
\hline $\mathrm{C}(8)-\mathrm{C}(7)-\mathrm{C}(6)$ & $121.1(2)$ \\
\hline $\mathrm{C}(8)-\mathrm{C}(7)-\mathrm{H}(7)$ & 119.4 \\
\hline $\mathrm{C}(6)-\mathrm{C}(7)-\mathrm{H}(7)$ & 119.4 \\
\hline $\mathrm{C}(7)-\mathrm{C}(8)-\mathrm{C}(9)$ & $121.4(2)$ \\
\hline $\mathrm{C}(7)-\mathrm{C}(8)-\mathrm{H}(8)$ & 119.3 \\
\hline $\mathrm{C}(9)-\mathrm{C}(8)-\mathrm{H}(8)$ & 119.3 \\
\hline $\mathrm{C}(10)-\mathrm{C}(9)-\mathrm{C}(8)$ & $117.6(2)$ \\
\hline $\mathrm{C}(10)-\mathrm{C}(9)-\mathrm{H}(9)$ & 121.2 \\
\hline $\mathrm{C}(8)-\mathrm{C}(9)-\mathrm{H}(9)$ & 121.2 \\
\hline $\mathrm{C}(9)-\mathrm{C}(10)-\mathrm{C}(5)$ & $120.60(19)$ \\
\hline $\mathrm{C}(9)-\mathrm{C}(10)-\mathrm{C}(3)$ & 134.27(19) \\
\hline $\mathrm{C}(5)-\mathrm{C}(10)-\mathrm{C}(3)$ & 105.01(16) \\
\hline $\mathrm{C}(11)-\mathrm{N}(1)-\mathrm{N}(2)$ & $112.06(15)$ \\
\hline $\mathrm{C}(11)-\mathrm{N}(1)-\mathrm{C}(1)$ & $128.55(15)$ \\
\hline
\end{tabular}




\begin{tabular}{|c|c|}
\hline $\mathrm{N}(2)-\mathrm{N}(1)-\mathrm{C}(1)$ & $119.37(14)$ \\
\hline $\mathrm{C}(13)-\mathrm{N}(2)-\mathrm{N}(1)$ & $104.40(15)$ \\
\hline $\mathrm{N}(1)-\mathrm{C}(11)-\mathrm{C}(12)$ & $106.52(16)$ \\
\hline $\mathrm{N}(1)-\mathrm{C}(11)-\mathrm{H}(11)$ & 126.7 \\
\hline $\mathrm{C}(12)-\mathrm{C}(11)-\mathrm{H}(11)$ & 126.7 \\
\hline $\mathrm{C}(11)-\mathrm{C}(12)-\mathrm{C}(13)$ & $105.71(16)$ \\
\hline $\mathrm{C}(11)-\mathrm{C}(12)-\mathrm{Br}(1)$ & $127.29(14)$ \\
\hline $\mathrm{C}(13)-\mathrm{C}(12)-\mathrm{Br}(1)$ & $126.99(14)$ \\
\hline $\mathrm{N}(2)-\mathrm{C}(13)-\mathrm{C}(12)$ & $111.30(17)$ \\
\hline $\mathrm{N}(2)-\mathrm{C}(13)-\mathrm{H}(13)$ & 124.3 \\
\hline $\mathrm{C}(12)-\mathrm{C}(13)-\mathrm{H}(13)$ & 124.3 \\
\hline
\end{tabular}

Table S4. Anisotropic displacement parameters $\left(\AA^{2} \times 10^{3}\right)$ for $\mathbf{3 d}$. The anisotropic displacement factor exponent takes the form: $\quad-2 \pi^{2}\left[h^{2} a^{* 2} U^{11}+\ldots+2 h_{k} a^{*} b^{*} U^{12}\right]$

\begin{tabular}{lcccccc}
\hline & $\mathrm{U}^{11}$ & $\mathrm{U}^{22}$ & $\mathrm{U}^{33}$ & $\mathrm{U}^{23}$ & $\mathrm{U}^{13}$ & $\mathrm{U}$ \\
\hline $\mathrm{C}(1)$ & $29(1)$ & $29(1)$ & $28(1)$ & $-1(1)$ & $-4(1)$ & $-7(1)$ \\
$\mathrm{C}(2)$ & $30(1)$ & $34(1)$ & $39(1)$ & $-7(1)$ & $-3(1)$ & $-2(1)$ \\
$\mathrm{C}(3)$ & $28(1)$ & $40(1)$ & $36(1)$ & $-2(1)$ & $-9(1)$ & $-1(1)$ \\
$\mathrm{O}(1)$ & $34(1)$ & $38(1)$ & $27(1)$ & $1(1)$ & $-6(1)$ & $-6(1)$ \\
$\mathrm{C}(4)$ & $26(1)$ & $31(1)$ & $28(1)$ & $-2(1)$ & $-5(1)$ & $-2(1)$ \\
$\mathrm{C}(5)$ & $32(1)$ & $31(1)$ & $26(1)$ & $-5(1)$ & $-4(1)$ & $-9(1)$ \\
$\mathrm{C}(6)$ & $49(1)$ & $32(1)$ & $30(1)$ & $-6(1)$ & $-8(1)$ & $-7(1)$ \\
$\mathrm{C}(7)$ & $77(2)$ & $38(1)$ & $33(1)$ & $-3(1)$ & $-8(1)$ & $-28(1)$ \\
$\mathrm{C}(8)$ & $63(2)$ & $63(2)$ & $37(1)$ & $-7(1)$ & $-3(1)$ & $-41(1)$ \\
$\mathrm{C}(9)$ & $37(1)$ & $65(2)$ & $37(1)$ & $-11(1)$ & $-5(1)$ & $-22(1)$ \\
$\mathrm{C}(10)$ & $34(1)$ & $40(1)$ & $27(1)$ & $-7(1)$ & $-5(1)$ & $-10(1)$ \\
$\mathrm{N}(1)$ & $32(1)$ & $30(1)$ & $26(1)$ & $0(1)$ & $-8(1)$ & $-8(1)$ \\
$\mathrm{N}(2)$ & $38(1)$ & $45(1)$ & $27(1)$ & $0(1)$ & $-10(1)$ & $-15(1)$ \\
$\mathrm{C}(11)$ & $42(1)$ & $35(1)$ & $26(1)$ & $2(1)$ & $-8(1)$ & $-13(1)$ \\
$\mathrm{C}(12)$ & $30(1)$ & $29(1)$ & $31(1)$ & $0(1)$ & $-5(1)$ & $-7(1)$ \\
$\mathrm{C}(13)$ & $35(1)$ & $43(1)$ & $33(1)$ & $-1(1)$ & $-11(1)$ & $-14(1)$ \\
$\mathrm{Br}(1)$ & $50(1)$ & $46(1)$ & $40(1)$ & $7(1)$ & $-6(1)$ & $-23(1)$ \\
\hline
\end{tabular}


Table S5. Hydrogen coordinates ( x 104) and isotropic displacement parameters $\left(\AA^{2} \times 10^{3}\right.$ ) for $3 d$.

\begin{tabular}{lrrrl}
\hline & $x$ & $y$ & $z$ & $U(e q)$ \\
& & & & \\
$H(1)$ & 3075 & 5173 & 9160 & 34 \\
$H(2 A)$ & 119 & 6409 & 8959 & 42 \\
$H(2 B)$ & 964 & 7641 & 7791 & 42 \\
$H(3)$ & -290 & 6274 & 6243 & 42 \\
$H(4)$ & 4978 & 4220 & 6555 & 35 \\
$H(6)$ & 4095 & 1427 & 8015 & 44 \\
$H(7)$ & 1594 & 114 & 8708 & 56 \\
$H(8)$ & -1450 & 1306 & 8566 & 61 \\
$H(9)$ & -2144 & 3854 & 7711 & 53 \\
$H(11)$ & 4864 & 7439 & 5717 & 40 \\
$H(13)$ & 6763 & 8576 & 9102 & 43 \\
& & & & \\
\hline
\end{tabular}

Table S6. Torsion angles $\left[{ }^{\circ}\right]$ for $\mathbf{3 d}$.

\begin{tabular}{|c|c|}
\hline $\mathrm{N}(1)-\mathrm{C}(1)-\mathrm{C}(2)-\mathrm{C}(3)$ & $120.12(16)$ \\
\hline $\mathrm{C}(4)-\mathrm{C}(1)-\mathrm{C}(2)-\mathrm{C}(3)$ & $1.17(18)$ \\
\hline $\mathrm{C}(1)-\mathrm{C}(2)-\mathrm{C}(3)-\mathrm{O}(1)$ & $-36.34(18)$ \\
\hline $\mathrm{C}(1)-\mathrm{C}(2)-\mathrm{C}(3)-\mathrm{C}(10)$ & $69.47(18)$ \\
\hline $\mathrm{C}(10)-\mathrm{C}(3)-\mathrm{O}(1)-\mathrm{C}(4)$ & $-52.13(15)$ \\
\hline $\mathrm{C}(2)-\mathrm{C}(3)-\mathrm{O}(1)-\mathrm{C}(4)$ & $58.60(16)$ \\
\hline $\mathrm{C}(3)-\mathrm{O}(1)-\mathrm{C}(4)-\mathrm{C}(5)$ & $52.06(15)$ \\
\hline $\mathrm{C}(3)-\mathrm{O}(1)-\mathrm{C}(4)-\mathrm{C}(1)$ & $-58.16(15)$ \\
\hline $\mathrm{N}(1)-\mathrm{C}(1)-\mathrm{C}(4)-\mathrm{O}(1)$ & $-85.29(16)$ \\
\hline $\mathrm{C}(2)-\mathrm{C}(1)-\mathrm{C}(4)-\mathrm{O}(1)$ & $34.59(16)$ \\
\hline $\mathrm{N}(1)-\mathrm{C}(1)-\mathrm{C}(4)-\mathrm{C}(5)$ & $168.72(14)$ \\
\hline$C(2)-C(1)-C(4)-C(5)$ & $-71.39(17)$ \\
\hline $\mathrm{O}(1)-\mathrm{C}(4)-\mathrm{C}(5)-\mathrm{C}(6)$ & $149.3(2)$ \\
\hline$C(1)-C(4)-C(5)-C(6)$ & $-104.4(2)$ \\
\hline $\mathrm{O}(1)-\mathrm{C}(4)-\mathrm{C}(5)-\mathrm{C}(10)$ & $-33.05(17)$ \\
\hline$C(1)-C(4)-C(5)-C(10)$ & $73.21(17)$ \\
\hline$C(10)-C(5)-C(6)-C(7)$ & $0.2(3)$ \\
\hline$C(4)-C(5)-C(6)-C(7)$ & $177.46(18)$ \\
\hline
\end{tabular}




\begin{tabular}{|c|c|}
\hline $\mathrm{C}(5)-\mathrm{C}(6)-\mathrm{C}(7)-\mathrm{C}(8)$ & $-1.1(3)$ \\
\hline $\mathrm{C}(6)-\mathrm{C}(7)-\mathrm{C}(8)-\mathrm{C}(9)$ & $0.4(3)$ \\
\hline $\mathrm{C}(7)-\mathrm{C}(8)-\mathrm{C}(9)-\mathrm{C}(10)$ & $1.2(3)$ \\
\hline $\mathrm{C}(8)-\mathrm{C}(9)-\mathrm{C}(10)-\mathrm{C}(5)$ & $-2.1(3)$ \\
\hline $\mathrm{C}(8)-\mathrm{C}(9)-\mathrm{C}(10)-\mathrm{C}(3)$ & $-177.3(2)$ \\
\hline $\mathrm{C}(6)-\mathrm{C}(5)-\mathrm{C}(10)-\mathrm{C}(9)$ & $1.5(3)$ \\
\hline $\mathrm{C}(4)-\mathrm{C}(5)-\mathrm{C}(10)-\mathrm{C}(9)$ & $-176.52(17)$ \\
\hline $\mathrm{C}(6)-\mathrm{C}(5)-\mathrm{C}(10)-\mathrm{C}(3)$ & $177.89(16)$ \\
\hline $\mathrm{C}(4)-\mathrm{C}(5)-\mathrm{C}(10)-\mathrm{C}(3)$ & $-0.08(18)$ \\
\hline $\mathrm{O}(1)-\mathrm{C}(3)-\mathrm{C}(10)-\mathrm{C}(9)$ & $-151.3(2)$ \\
\hline $\mathrm{C}(2)-\mathrm{C}(3)-\mathrm{C}(10)-\mathrm{C}(9)$ & $103.2(2)$ \\
\hline $\mathrm{O}(1)-\mathrm{C}(3)-\mathrm{C}(10)-\mathrm{C}(5)$ & $33.01(18)$ \\
\hline $\mathrm{C}(2)-\mathrm{C}(3)-\mathrm{C}(10)-\mathrm{C}(5)$ & $-72.49(18)$ \\
\hline $\mathrm{C}(4)-\mathrm{C}(1)-\mathrm{N}(1)-\mathrm{C}(11)$ & $42.4(2)$ \\
\hline $\mathrm{C}(2)-\mathrm{C}(1)-\mathrm{N}(1)-\mathrm{C}(11)$ & $-70.3(2)$ \\
\hline $\mathrm{C}(4)-\mathrm{C}(1)-\mathrm{N}(1)-\mathrm{N}(2)$ & $-139.44(16)$ \\
\hline $\mathrm{C}(2)-\mathrm{C}(1)-\mathrm{N}(1)-\mathrm{N}(2)$ & $107.89(18)$ \\
\hline $\mathrm{C}(11)-\mathrm{N}(1)-\mathrm{N}(2)-\mathrm{C}(13)$ & $-0.3(2)$ \\
\hline $\mathrm{C}(1)-\mathrm{N}(1)-\mathrm{N}(2)-\mathrm{C}(13)$ & $-178.71(16)$ \\
\hline $\mathrm{N}(2)-\mathrm{N}(1)-\mathrm{C}(11)-\mathrm{C}(12)$ & $0.4(2)$ \\
\hline $\mathrm{C}(1)-\mathrm{N}(1)-\mathrm{C}(11)-\mathrm{C}(12)$ & $178.69(17)$ \\
\hline $\mathrm{N}(1)-\mathrm{C}(11)-\mathrm{C}(12)-\mathrm{C}(13)$ & $-0.4(2)$ \\
\hline $\mathrm{N}(1)-\mathrm{C}(11)-\mathrm{C}(12)-\mathrm{Br}(1)$ & $178.47(13)$ \\
\hline $\mathrm{N}(1)-\mathrm{N}(2)-\mathrm{C}(13)-\mathrm{C}(12)$ & $0.0(2)$ \\
\hline $\mathrm{C}(11)-\mathrm{C}(12)-\mathrm{C}(13)-\mathrm{N}(2)$ & $0.3(2)$ \\
\hline $\mathrm{Br}(1)-\mathrm{C}(12)-\mathrm{C}(13)-\mathrm{N}(2)$ & $-178.62(14)$ \\
\hline & \\
\hline & \\
\hline
\end{tabular}

Symmetry transformations used to generate equivalent atoms: 